National Water-Quality Assessment Program

\title{
Assessment of Nutrient Enrichment by Use of Algal-, Invertebrate-, and Fish-Community Attributes in Wadeable Streams in Ecoregions surrounding the Great Lakes
}

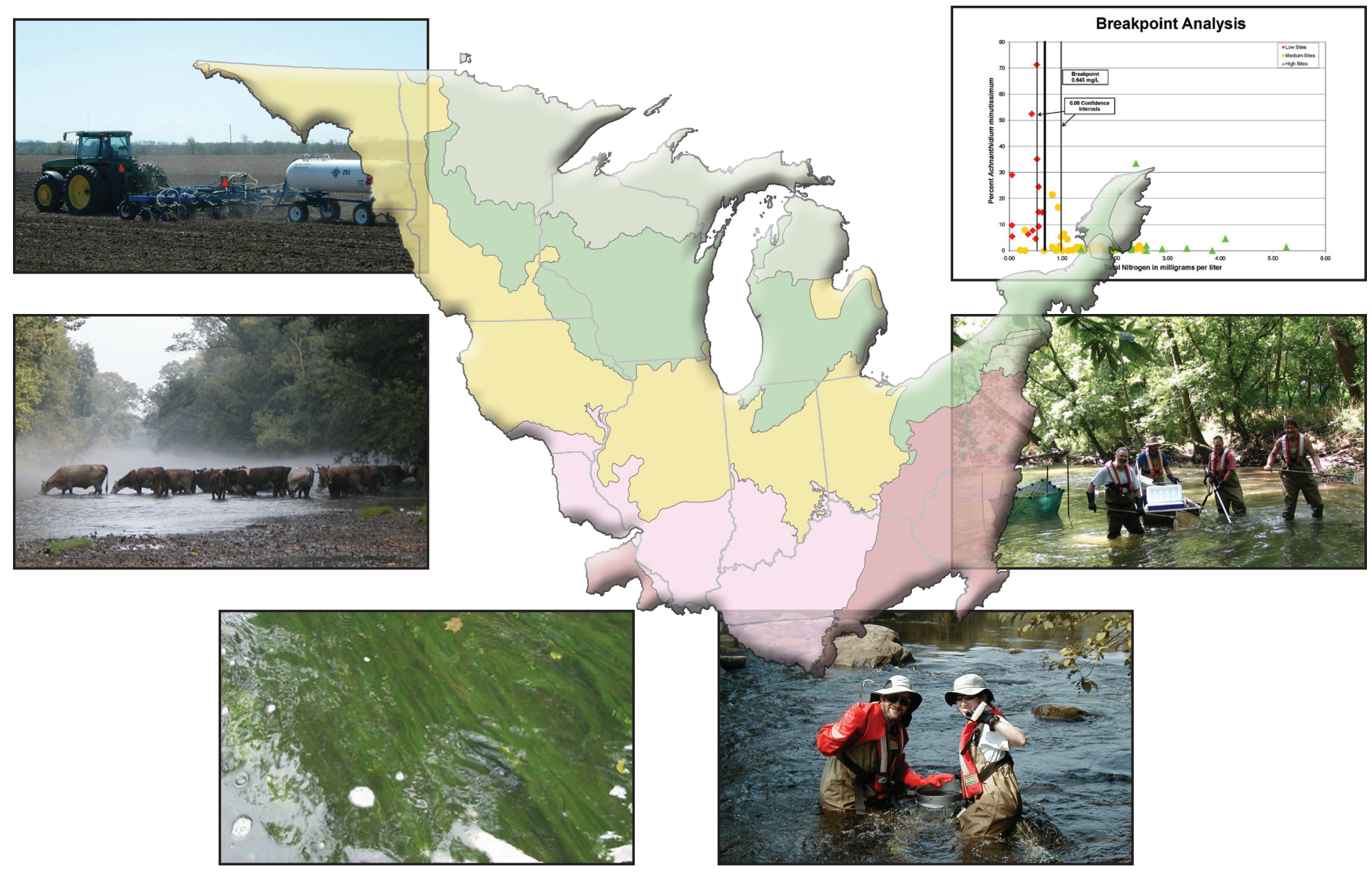

Scientific Investigations Report 2011-5009 


\section{Cover images (from let to right):}

Tractor applying fertilizer in the Sugar Creek watershed in Hancock County, Indiana, June 7, 2007. (Photograph by John T. Wilson, U.S. Geological Survey (USGS))

Cows drinking in the Mad River, August 25, 2003. (Photograph by Stephanie D. Janosy, USGS)

An algal mass in a stream from an unknown location in Indiana.

USGS employees collecting an invertebrate community sample from the Popple River, Wisconsin, on September 10, 2003. (Photograph by Barbara C. Eikenberry, USGS)

USGS employees collecting a fish-community sample from Sugar Creek at New Palestine, Indiana, in Hancock County on August 15, 2008. (Photograph by David S. Nail, USGS)

Scatter plot showing breakpoint analysis of total nitrogen and Achnanthidium minutissimum in the Glacial North diatom ecoregion. 


\section{Assessment of Nutrient Enrichment by Use of Algal-, Invertebrate-, and Fish- Community Attributes in Wadeable Streams in Ecoregions surrounding the Great Lakes}

By Jeffrey W. Frey, Amanda H. Bell, Julie A. Hambrook Berkman, and David L. Lorenz

National Water-Quality Assessment Program

Scientific Investigations Report 2011-5009 


\title{
U.S. Department of the Interior \\ KEN SALAZAR, Secretary \\ U.S. Geological Survey \\ Marcia K. McNutt, Director
}

\section{U.S. Geological Survey, Reston, Virginia: 2011}

\author{
For more information on the USGS - the Federal source for science about the Earth, its natural and living resources, \\ natural hazards, and the environment, visit http://www.usgs.gov or call 1-888-ASK-USGS \\ For an overview of USGS information products, including maps, imagery, and publications, \\ visit http://www.usgs.gov/pubprod \\ To order this and other USGS information products, visit http://store.usgs.gov
}

\begin{abstract}
Any use of trade, product, or firm names is for descriptive purposes only and does not imply endorsement by the U.S. Government.

Although this report is in the public domain, permission must be secured from the individual copyright owners to reproduce any copyrighted materials contained within this report.
\end{abstract}

Suggested citation:

Frey, J.W., Bell, A.H., Hambrook Berkman, J.A., and Lorenz, D.L., 2011, Assessment of nutrient enrichment by use of algal-, invertebrate-, and fish-community attributes in wadeable streams in ecoregions surrounding the Great Lakes: U.S. Geological Survey Scientific Investigations Report 2011-5009, 49 p. 


\section{Contents}

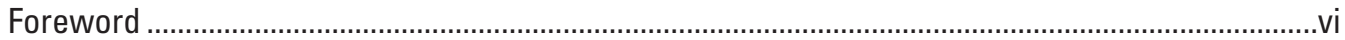

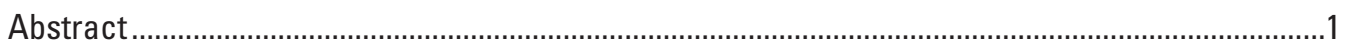

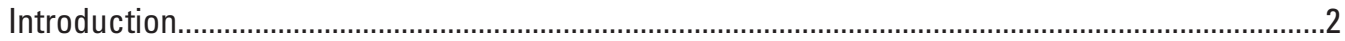

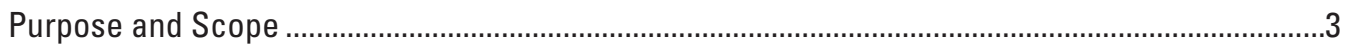

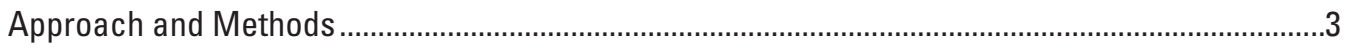

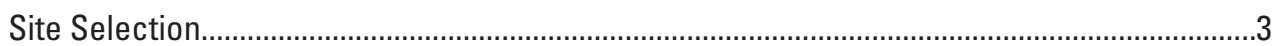

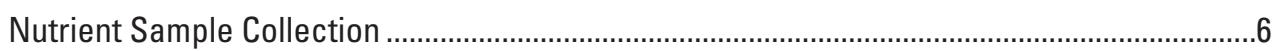

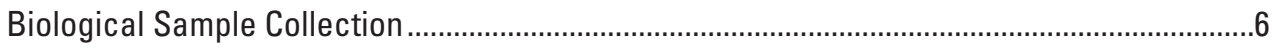

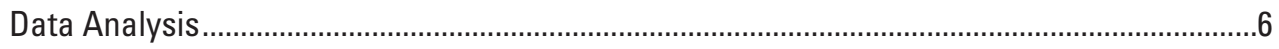

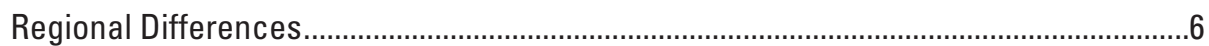

Nutrient Conditions of the Sites ..........................................................................................

Biological Conditions of the Sites ....................................................................................

Using Biological and Nutrient Conditions to Describe Differences between Sites .......12

Description of Regional Differences and the Nutrient and Biological Conditions in the Nutrient Categories .................................................................................................... 14

Regional Biological Differences.............................................................................................14

Regional Comparisons of the Nutrient Categories.....................................................................15

Comparison of Seasonal Nutrient Concentrations by Nutrient Categories.............................19

Biological Conditions Within the Nutrient Categories.............................................................20

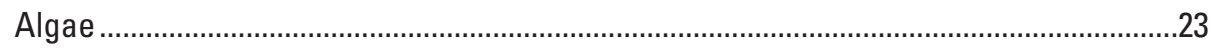

Central and Western Plains Ecoregion ...............................................................23

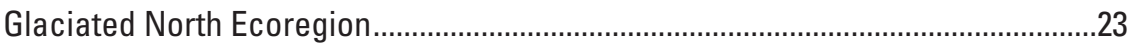

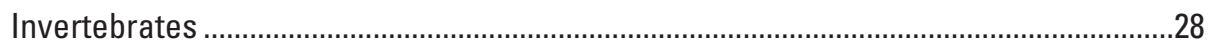

Central and Western Plains Ecoregion ..................................................................28

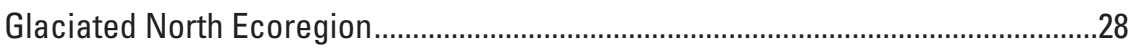

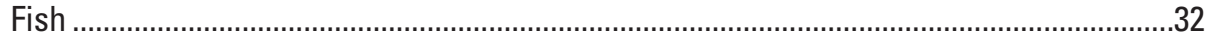

Central and Western Plains Ecoregion ..................................................................32

Glaciated North Ecoregion......................................................................................32

Breakpoint Analysis Between Nutrients and Biological Attributes .............................................35

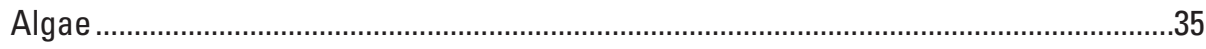

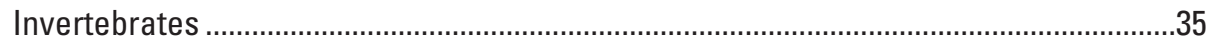

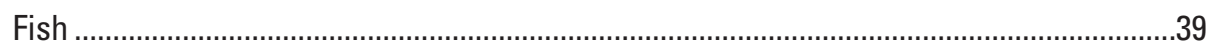

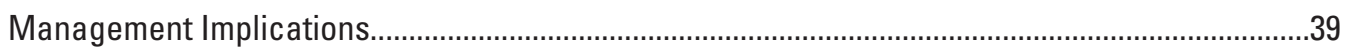

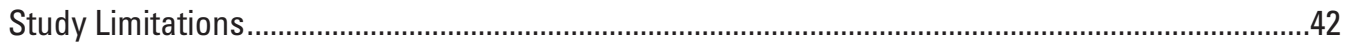

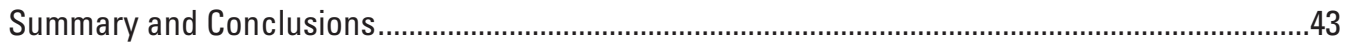

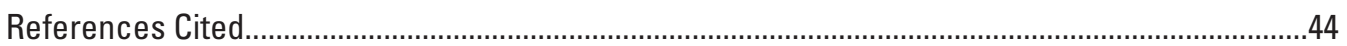




\section{Figures}

1. Map showing National Water-Quality Assessment Program Major River Basins (MRB)

2. Map showing locations of the nutrient and diatom ecoregions and sampling sites ........5

3. Ordination plots showing the algae-, invertebrate-, and fish-community data ...............14

4-10. Boxplots showing:

4. Distribution of median annual total nitrogen concentrations in the low-, medium-, and high-nutrient categories in the Central and Western Plains and Glacial North diatom ecoregions .

5. Distribution of median annual total phosphorus concentrations in the low-, medium-, and high-nutrient categories in the Central and Western Plains and Glacial North diatom ecoregions

6. Monthly concentrations of total nitrogen at the 64 sites within Central and Western Plains and Glacial North diatom ecoregions used to determine nutrient categories

7. Seasonal concentrations of total nitrogen (TN) at the low-TN site Muscatatuck River, Indiana

8. Seasonal concentrations of total nitrogen (TN) at the medium-TN site Sugar Creek, Indiana.

9. Seasonal concentrations of total nitrogen (TN) at the high-TN site Little Cobb River, Minnesota.....

10. Monthly concentrations of total phosphorus at the 64 sites within Central and Western Plains and Glacial North diatom ecoregions used to determine nutrient categories.

\section{Tables}

1. Location, drainage area, diatom ecoregion, and period-of-record data of the 64 sampling sites in the Central and Western Plains and Glacial North diatom ecoregions.

2. Nutrient categories for total nitrogen and total phosphorus in the Central and Western Plains and Glaciated North diatom ecoregions ....

3. Spearman rank correlation coefficients from the analysis of similarity between the three diatom ecoregions.

4. Summary of Spearman rho correlations for the nutrients total nitrogen and total phosphorus and the algae, invertebrate, and fish community.

5. Level III ecoregion, diatom ecoregion, and nutrient categories of the 54 sampling sites in the Central and Western Plains and Glacial North diatom ecoregions.

6. Summary statistics for total nitrogen and total phosphorus in the Central and Western Plains and Glacial North diatom ecoregions 
7. Spearman rank correlation coefficients from the analysis of similarity between the three nutrient categories.

8. Most abundant algal taxa in the total nitrogen and total phosphorus nutrient categories in the Central and Western Plains and Glacial North diatom ecoregions..

9. Most abundant invertebrate taxa in the total nitrogen and total phosphorus nutrient categories in the Central and Western Plains and Glacial North diatom ecoregions

10. Most relative abundant fish species in the total nitrogen and total phosphorus nutrient categories in the Central and Western Plains and Glacial North diatom ecoregions

11. Breakpoints between nutrients and the most significant biological metrics in the Central and Western Plains and Glacial North diatom ecoregions

12. Comparison of the number of sites in low, medium, and high nutrient categories based on nutrient and biological classifications of stream conditions

\section{Conversion Factors}

\begin{tabular}{lll}
\hline Multiply & By & To obtain \\
\hline & Length & \\
\hline micrometer $(\mathrm{cm})$ & 0.00003937 & inch (in.) \\
\hline & Area & \\
\hline square kilometer $\left(\mathrm{km}^{2}\right)$ & 0.3861 & square mile $\left(\mathrm{mi}^{2}\right)$ \\
\hline
\end{tabular}

Temperature in degrees Celsius $\left({ }^{\circ} \mathrm{C}\right)$ may be converted to degrees Fahrenheit $\left({ }^{\circ} \mathrm{F}\right)$ as follows: ${ }^{\circ} \mathrm{F}=\left(1.8 \times^{\circ} \mathrm{C}\right)+32$

Horizontal coordinate information is referenced to the North American Datum of 1983 (NAD 83).

Concentrations of chemical constituents in water are given in milligrams per liter (mg/L). 


\section{Foreword}

The U.S. Geological Survey (USGS) is committed to providing the Nation with reliable scientific information that helps to enhance and protect the overall quality of life and that facilitates effective management of water, biological, energy, and mineral resources ( $h t t p: / / w w w . u s g s$. gov/. Information on the Nation's water resources is critical to ensuring long-term availability of water that is safe for drinking and recreation and is suitable for industry, irrigation, and fish and wildlife. Population growth and increasing demands for water make the availability of that water, measured in terms of quantity and quality, even more essential to the long-term sustainability of our communities and ecosystems.

The USGS implemented the National Water-Quality Assessment (NAWQA) Program in 1991 to support national, regional, State, and local information needs and decisions related to waterquality management and policy (http://water.usgs.gov/nawqa). The NAWQA Program is designed to answer: What is the quality of our Nation's streams and ground water? How are conditions changing over time? How do natural features and human activities affect the quality of streams and ground water, and where are those effects most pronounced? By combining information on water chemistry, physical characteristics, stream habitat, and aquatic life, the NAWQA Program aims to provide science-based insights for current and emerging water issues and priorities. From 1991 to 2001, the NAWQA Program completed interdisciplinary assessments and established a baseline understanding of water-quality conditions in 51 of the Nation's river basins and aquifers, referred to as Study Units (http://water.usgs.gov/nawqa/studies/ study_units.html).

In the second decade of the Program (2001-2012), a major focus is on regional assessments of water-quality conditions and trends. These regional assessments are based on major river basins and principal aquifers, which encompass larger regions of the country than the Study Units. Regional assessments extend the findings in the Study Units by filling critical gaps in characterizing the quality of surface water and ground water, and by determining water-quality status and trends at sites that have been consistently monitored for more than a decade. In addition, the regional assessments continue to build an understanding of how natural features and human activities affect water quality. Many of the regional assessments employ modeling and other scientific tools, developed on the basis of data collected at individual sites, to help extend knowledge of water quality to unmonitored, yet comparable areas within the regions. The models thereby enhance the value of our existing data and our understanding of the hydrologic system. In addition, the models are useful in evaluating various resource-management scenarios and in predicting how our actions, such as reducing or managing nonpoint and point sources of contamination, land conversion, and altering flow and (or) pumping regimes, are likely to affect water conditions within a region. 
Other activities planned during the second decade include continuing national syntheses of information on pesticides, volatile organic compounds (VOCs), nutrients, trace elements, and aquatic ecology; and continuing national topical studies on the fate of agricultural chemicals, effects of urbanization on stream ecosystems, bioaccumulation of mercury in stream ecosystems, effects of nutrient enrichment on stream ecosystems, and transport of contaminants to public-supply wells.

The USGS aims to disseminate credible, timely, and relevant science information to address practical and effective water-resource management and strategies that protect and restore water quality. We hope this NAWQA publication will provide you with insights and information to meet your needs, and will foster increased citizen awareness and involvement in the protection and restoration of our Nation's waters.

The USGS recognizes that a national assessment by a single program cannot address all waterresource issues of interest. External coordination at all levels is critical for cost-effective management, regulation, and conservation of our Nation's water resources. The NAWQA Program, therefore, depends on advice and information from other agencies-Federal, State, regional, interstate, Tribal, and local — as well as nongovernmental organizations, industry, academia, and other stakeholder groups. Your assistance and suggestions are greatly appreciated.

William H. Werkheiser

USGS Associate Director for Water 



\title{
Assessment of Nutrient Enrichment by Use of Algal-, Invertebrate-, and Fish-Community Attributes in Wadeable Streams in Ecoregions surrounding the Great Lakes
}

\author{
By Jeffrey W. Frey, Amanda H. Bell, Julie A. Hambrook Berkman, and David L. Lorenz
}

\section{Abstract}

The algal, invertebrate, and fish taxa and community attributes that best reflect the effects of nutrients along a gradient of low to high nutrient concentrations in wadeable, primarily midwestern streams were determined as part of the U.S. Geological Suvey's National Water-Quality Assessment (NAWQA) Program. Nutrient data collected from 64 sampling sites that reflected reference, agricultural, and urban influences between 1993 and 2006 were used to represent the nutrient gradient within Nutrient Ecoregion VI (Cornbelt and Northern Great Plains), VII (Mostly Glaciated Dairy Region), and VIII (Nutrient Poor Largely Glaciated Upper Midwest and Northeast). Nutrient Ecoregions VII and VIII comprise the Glacial North diatom ecoregion (GNE) and Nutrient Ecoregion VI represents the Central and Western Plains diatom ecoregion (CWPE). The diatom-ecoregion groupings were used chiefly for data analysis.

The total nitrogen (TN) and total phosphorus (TP) data from 64 sites, where at least 6 nutrient samples were collected within a year at each site, were used to classify the sites into low-, medium-, and high-nutrient categories based upon the 10th and 75th percentiles of for sites within each Nutrient Ecoregion. In general, TN and TP concentrations were 3-5 times greater in Nutrient Ecoregion VI than in Nutrient Ecoregions VII and VIII.

A subgroup of 54 of these 64 sites had algal-, invertebrate-, and fish-community data that were collected within the same year as the nutrients; these sites were used to assess the effects of nutrients on the biological communities. Multidimensional scaling was used to determine whether the entire region could be assessed together or whether there were regional differences between the algal, invertebrate, and fish communities. The biological communities were significantly different between the northern sites, primarily in the GNE and the southern sites, primarily in the CWPE.
In the higher nutrient concentration gradient in the streams of the CWPE, algae exhibited greater differences than invertebrates and fish between all of the nutrient categories for both TN and TP; however, in the lower nutrient gradient in the streams of the GNE, invertebrates exhibited greater differences between the nutrient categories. Certain species of algae, invertebrates, and fish were more prevalent in low- and high-nutrient categories within each of the diatom ecoregions. Breakpoint analysis was used to identify the concentration at which the relations between the response variable (biological attribute) and the stressor variable (TN and TP) change. There were significant breakpoints for nutrients (TN and TP) and multiple attributes for algae, invertebrates, and fish communities within the CWPE and GNE diatom ecoregions. In general, more significant breakpoints, with lower concentrations, were found in the GNE than the more nutrient-rich CWPE. The breakpoints from all biological communities were generally about 3-5 times higher in the south (CWPE) than the north (GNE). In the north, breakpoints with similar lower concentrations were found for TN from all biological communities (around 0.60 milligram per liter) and for TP (between 0.02 and 0.03 milligram per liter) for the algae and invertebrate communities.

The findings from our study suggest that the range in breakpoints for TN and TP from the GNE can be used as oligotrophic and eutrophic boundaries derived from biological response based on this ecoregion having (1) a gradient with sufficiently low to high nutrient concentrations, (2) distinctive differences in the biological communities in the low- to highnutrient streams, (3) similarity of breakpoints within algal, invertebrate, and fish communities, (4) significant attributes with either direct relations to nutrients or traditional changes in community structure (that is, decreases in sensitive species or increases in tolerant species), and (5) similar breakpoints in other studies in this and other regions. In nutrient-rich areas like the CWPE, all of the breakpoints were substantially higher than those for the lower nutrient conditions of the GNE, suggesting that streams are nutrient saturated to the point that low-end breakpoints cannot be detected. 


\section{Introduction}

Nutrients - an element or compound used in animal and plant growth - are essential to all life, as well as to the health and diversity of surface waters; in excessive amounts, however, nutrients can have potentially negative human-health, ecological, and economic consequences. Excess amounts of nitrogen $(\mathrm{N})$ and phosphorus $(\mathrm{P})$ in particular have been shown to cause eutrophication in aquatic ecosystems, which sometimes has been linked to fish kills, shifts in species composition, unpleasant taste and odor in drinking water, blooms of harmful algae in freshwater bodies and estuaries, and hypoxic and anoxic zones in gulfs and estuaries (U.S. Environmental Protection Agency, 2000c,d; Munn and Hamilton, 2003).

Many streams within the United States have been placed on the Clean Water Act (CWA) Section 303(d) list of impaired water bodies because of excess nutrients. The CWA, as amended in 1976, established a national goal of achieving water quality to provide for the protection and propagation of aquatic organisms, wildlife, and recreation in and on water; regulation to achieve this goal is the responsibility of the U.S. Environmental Protection Agency (USEPA). In 1996, the USEPA National Water Quality Inventory identified excess nutrients as second only to siltation as a leading cause of impairment of U.S. rivers and streams (U.S. Environmental Protection Agency, 1997). In 2000, the USEPA proposed ecoregion-specific nutrient water-quality criteria for the causal variables total nitrogen (TN) and total phosphorus (TP) and for the response variables periphyton chlorophyll $a$ (CHLa), seston CHL $a$, and turbidity, to improve the health in rivers and streams from excess nutrients. However, little or no CHL $a$ data existed or were available for most of the USEPA Nutrient Ecoregions, and criteria were proposed for periphyton CHL $a$ for limited Nutrient Ecoregions in the United States (U.S. Environmental Protection Agency, 2000a,b,c,d).

USEPA drinking-water criteria (Maximum Contaminant Levels) are $10 \mathrm{mg} / \mathrm{L}$ for nitrate as $\mathrm{N}$ and $1 \mathrm{mg} / \mathrm{L}$ for nitrite as N (U.S. Environmental Protection Agency, 2005). In addition, aquatic-life criteria established to protect aquatic organisms have been set for ammonia as $\mathrm{N}$ (the ammonia as $\mathrm{N}$ aquaticlife criterion varies with $\mathrm{pH}$, temperature, and life stage) (U.S. Environmental Protection Agency, 2005). Yet, these criteria do not address the effects of increased nutrients on the biological communities in rivers and streams. Typically, nutrient concentrations must be extremely high to be toxic to biological communities; such concentrations rarely are found in the environment (Rankin and others, 1999). Exceptions are concentrations of ammonia associated with accidental discharges from wastewater-treatment facilities, combined-sewer overflows, or concentrated-animal feeding operations (Rankin and others, 1999).

Although the USEPA proposed criteria for nutrients as causal variables and periphyton and seston CHL $a$ as response variables, direct correlations or models that predict CHL $a$ on the basis of nutrients often are weak, and statistical significance of the correlations has varied from study to study. For example, previous studies of nutrient-rich agricultural streams in Illinois (Figueroa-Nieves and others, 2006) and Indiana (Lowe and others, 2008) found few significant relations among concentrations of $\mathrm{N}$ or $\mathrm{P}$ and periphyton or seston CHL $a$. In contrast, Biggs (2000) listed several studies that found significant relations between nutrients and periphyton CHLa. Dodds and others (1998) found significant relations between TN and TP and periphyton CHL $a$ for temperate streams. In Wisconsin, significant relations were found between nitrate, TN, dissolved P (DP), and TP and periphyton CHL $a$ in wadeable streams (Robertson and others, 2006) and seston CHL $a$ in nonwadeable streams (Robertson and others, 2008). Dodds and others (2002) presented regression models that predict periphyton CHL $a$ as a function of $\mathrm{N}$ and (or) $\mathrm{P}$ and found coefficients of determination $\left(\mathrm{r}^{2}\right)$ values that ranged from 0.1 to 0.40 . A primary reason for the weak relations between algal biomass and nutrients in streams is the complex interactions of physical and biological factors. In general, the addition of nutrients stimulates the growth of algae; however, physical variables such as light limitation from canopy shading (Mosisch and others, 2001), turbidity (Munn and others, 1989), and water temperature (Kilkus and others, 1975; Munn and others, 1989) can limit algal growth. Moreover, various physical and biological factors can decrease existing algal growth and confound the nutrient-algal biomass relations (Munn and others, 2010). For example, increased streamflow, elevated suspended-sediment concentrations, and scouring are physical factors that decrease algal biomass (Power, 1992; Biggs, 1995), whereas grazing by invertebrates or fish biologically decreases algal biomass (Lamberti and Resh, 1983; Power, 1992). Additionally, pesticides used to control unwanted plant growth also have been reported to decrease algal biomass in agricultural streams (Kosinski, 1984).

The lack of strong relations between nutrients and CHL $a$ suggests that biological communities will be important in understanding the true nutrient condition in streams. Multimetric indices of biotic integrity for fish and invertebrate communities have been successfully used throughout the United States (Karr and others, 1986; Ohio Environmental Protection Agency, 1987a,b, 1989; Bryce and Hughes, 2002) and worldwide to measure effects of human disturbances on streams. More recently, periphyton (benthic) diatom indices have been successfully used to measure differences in water quality between reference (high-quality) and impaired sites at scales ranging from state (Fore and Grafe, 2002) to ecoregion (Wang and others, 2005) and geographic region (Fore, 2003; Porter and others, 2008). Idaho, Kentucky (Kentucky Division of Water, 2002), Michigan, Montana (Teply and Bahls, 2005), and New York (Passy, 2000) have developed diatom indexes to determine whether streams need to be included on the 303(d) list of the Clean Water Act. In some studies, multimetric diatom indices were better than fish or invertebrate multimetric indices at differentiating the effects of nutrients (U.S. Environmental Protection Agency, 2006a; Justus and others, 2009). Fish and invertebrate indices developed by 
many states effectively distinguish between impaired and unimpaired streams; however, it has been more problematic to discover whether the primary ecosystem stressor is nutrient impairment or whether the stressor or stressors are related to land use, hydrology, habitat, or inputs of chemicals other than nutrients.

The study described herein is an attempt by the NAWQA Program to discover statistical relations between nutrient stressors and biotic response across a geographically wide network of water-quality sampling sites. Biological, waterquality, and ancillary data collected at certain sites as part of the NAWQA Program provide a description of water-quality conditions and allow for assessments of how natural features and human activities affect those conditions. Regional assessments are possible because of a consistent study design and uniform methods of data collection. Monitoring data are integrated with geographic information on hydrological characteristics, land use, and other landscape features in models to extend water-quality understanding to unmonitored areas. Local, State, Tribal, and national stakeholders use NAWQA information to design and implement strategies for managing, protecting, and monitoring water resources in many different hydrologic and land-use settings across the Nation.

\section{Purpose and Scope}

The purpose of this regional report is to describe which algal, invertebrate, and fish taxa and attributes best reflect the effects of nutrients at sites along a gradient of low- to high-nutrient conditions in the Great Lakes, Ohio, Upper Mississippi, and Souris-Red-Rainy River Basins; the U.S. Geological Survey (USGS) National Water-Quality Assessment (NAWQA) Program refers to these basins collectively as Major River Basin 3 (MRB3; fig. 1). These taxa and attributes can be used to determine more precise qualifications of nutrient impairments of streams in this area of the United States, particularly USEPA Nutrient Ecoregions VI, VII, and VIII.

The MRB3 region includes parts of seven USEPA Nutrient Ecoregions, but the sampling sites ultimately used in our study were all within four of them: VI, the Cornbelt and Northern Great Plains; VII, the Mostly Glaciated Dairy Region; VIII, Nutrient Poor Largely Glaciated Upper Midwest and Northeast; and IX, Southeastern Temperate and Forested Plains and Hills (U.S. Environmental Protection Agency, 2000c,d). Potapova and Charles (2007) combined three of these Nutrient Ecoregions into two diatom ecoregions based on similarities of algal diatom communities. Specifically, Nutrient Ecoregion VI corresponds to the Central and Western Plains diatom ecoregion (CWPE), and the combined Nutrient Ecoregions VII and VIII correspond to the Glacial North diatom ecoregion (GNE); Potapova and Charles' categorization was used as the regional basis for this study (fig. 2), so the study results will be discussed in terms of CWPE and the GNE hereafter in this report.

\section{Approach and Methods}

The approach used in our study was first to determine whether the invertebrate and fish communities within the CWPE and GNE are similar or whether they needed to be assessed separately, as was true for the algae. The analyses found the composition of the algae, invertebrate, and fish communities to be significantly different, so subsequent analyses on sites within the CWPE and the GNE were done separately. Nutrient variables were evaluated to determine which had the strongest relation with the biological communities and should be used in later analyses. The sampling sites were classified into low-, medium-, and high-nutrient categories based upon selected percentiles of TN and TP concentrations from a total of 64 NAWQA sites sampled during 1993-2006; these sites included those reflecting reference, agricultural, and urban conditions for both diatom ecoregions. The three nutrient categories provide the basis for comparisons of differences between the biological communities within each of the nutrient categories. A subgroup of 54 of the 64 NAWQA sites with at least 6 nutrient samples per year and with corresponding algae-, invertebrate-, and fish-community data were used to assess biological differences in nutrient categories. The attributes for the algae, invertebrates, and fish were analyzed to determine which biological attributes had the strongest correlations with TN and TP. Breakpoint analysis was used to find the concentration of TN and TP where the biological community dramatically changed with respect to the statistically strongest and most ecologically significant attributes. The differences in the biological communities and the breakpoints were assessed for use as measures of trophic level, management implications, and the development of nutrient criteria.

Data for our study were collected by use of standard NAWQA field and analytical methods. The following sections describe the site-selection and sampling strategies; field and laboratory methods used in collecting, processing, and analyzing nutrients; and statistical analyses used.

\section{Site Selection}

Biological communities are influenced by multiple instream habitat and water-quality-related variables such as substrate, water depth, velocity, nutrients, and clarity; they are additionally influenced by landscape-level variables such as land use, climate, and geology (Wehr and Sheath, 2003). Typically, most studies that examine how biological communities are affected by a specific stressor or groups of stressors try to minimize the variability associated with these regional differences so that the effects of the stressor(s) can be maximized. For example, most indices of biological integrity are developed for specific watersheds or ecoregions (Simon 1991, 1997; Potapova and Charles, 2007), in part to account for these regional differences. 


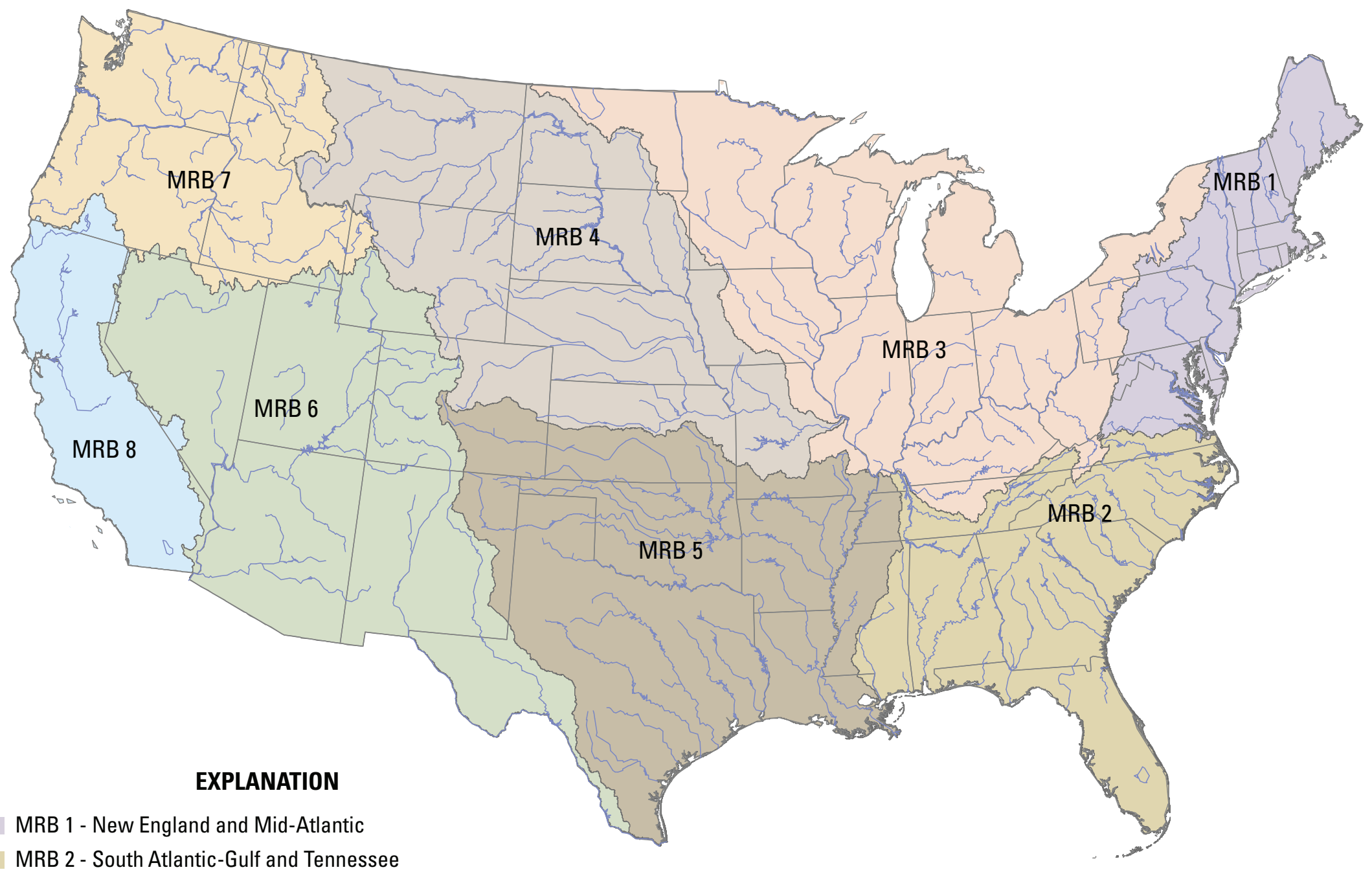

MRB 2 - South Atlantic-Gulf and Tennessee

MRB 3 - Great Lakes, Ohio, Upper Mississippi, and Souris-Red-Rainy

MRB 4 - Missouri

MRB 5 - Lower Mississippi, Arkansas-White-Red, and Texas-Gulf

MRB 6 - Rio Grande, Colorado, and Great Basin

MRB 7 - Pacific Northwest

MRB 8 - California

Figure 1. National Water-Quality Assessment Program Major River Basins (MRB). 


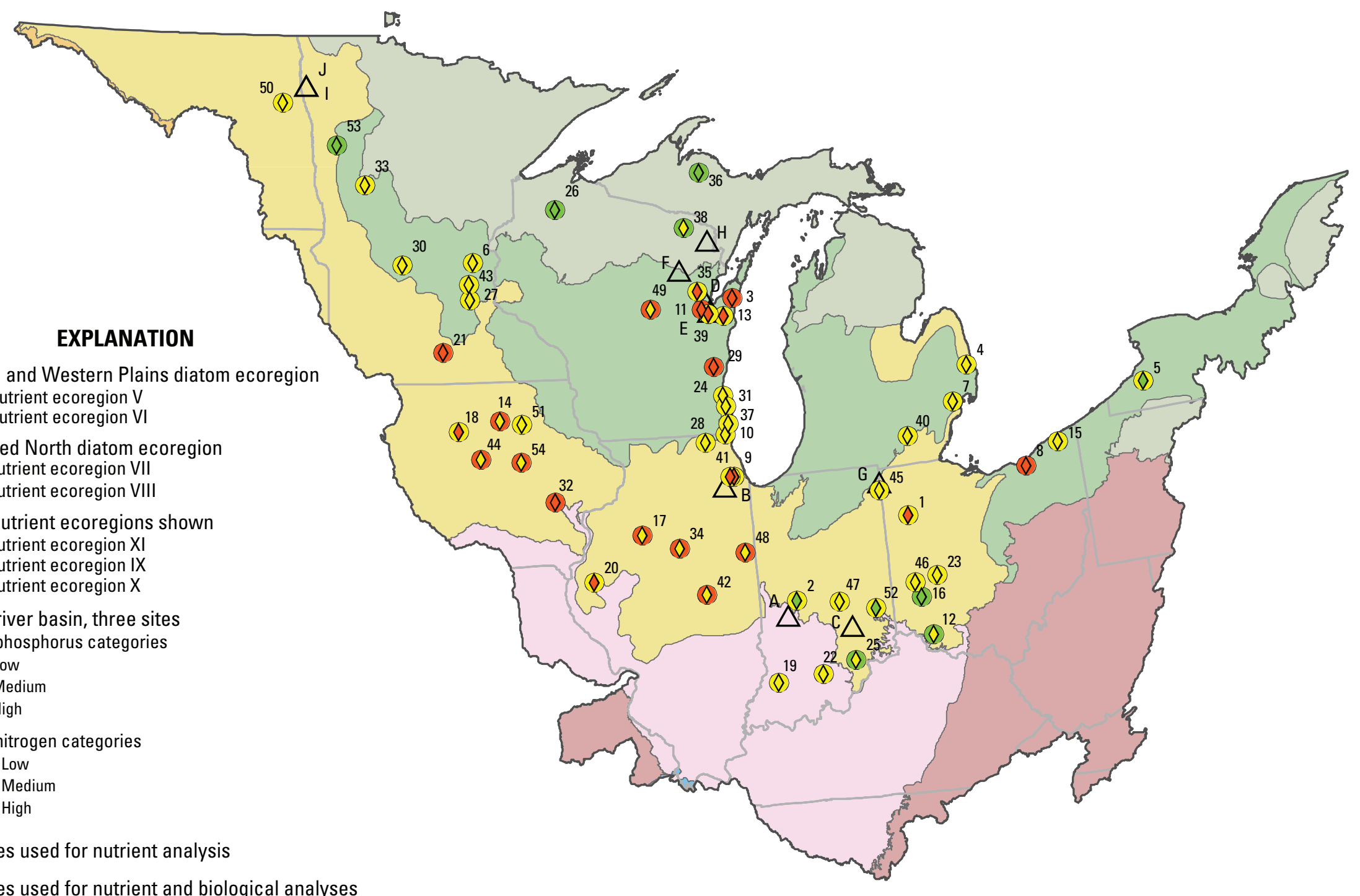

(Q) Sites used for nutrient and biological analyses 
Potapova and Charles (2007) classified the United States into five diatom ecoregions based on the U.S. Environmental Protection Agency's scheme of Nutrient Ecoregions, which itself is an aggregation of Omernik's level III ecoregions (Omernik, 1987, 1995; fig. 2). The development of the five diatom ecoregions entailed use of NAWQA algal data collected from 1993 through 2001 at 1,240 sites throughout the United States. For our study, site selection focused primarily on streams in the upper Midwest, with most sites located in the GNE or CWPE diatom ecoregions; two sites were in the Eastern Highlands (EHE) diatom ecoregion (Potapova and Charles, 2007). Multidimensional scaling analyses (Clarke and Ainsworth, 1993) were done to see whether regional differences such as those found in the diatom community were also characteristic of the invertebrate and fish communities.

Biological communities, especially fish communities, are influenced by stream size (Simon 1991, 1997; Goldstein and Meador, 2004; Hambrook Berkman and others, 2010). Most Index of Biological Integrity (IBI) methods distinguish attributes on the basis of basin size. To minimize the effect of varied drainage areas that could mask the effects of nutrients on biological communities, only wadeable sites are discussed in this report. Sites were selected to maximize the number of sites within each diatom ecoregion. Sites were classified by basin size (headwater, less than $52 \mathrm{~km}^{2}$; wadeable, greater than $52 \mathrm{~km}^{2}$ and less than $1,000 \mathrm{~km}^{2}$; and boat, greater than $1,000 \mathrm{~km}^{2}$ ) on the basis of classifications used by several states within the region (for example, Ohio Environmental Protection Agency, 1989; Indiana Department of Environmental Management, 1999).

\section{Nutrient Sample Collection}

All nutrient samples were collected according to standard NAWQA protocols as detailed below. Typically, samples were collected by using a depth-integrating sampler at multiple vertical locations in the stream cross section (Shelton, 1994). Samples for analysis of dissolved constituents were filtered in the field, within 2 hours of collection, through either a nitrocellulose filter or a polyether-sulfone medium with a pore size of $0.45 \mu \mathrm{m}$. Nutrient samples were chilled and maintained at $4^{\circ} \mathrm{C}$ until analyzed at the laboratory. The number of samples collected at a NAWQA site varied from 6 to 26 per year.

Ammonia $\left(\mathrm{NH}_{3}\right)$, nitrite $\left(\mathrm{NO}_{2}\right)$ plus nitrate $\left(\mathrm{NO}_{3}\right)$, and orthophosphate (OP) were analyzed according to methods described by Fishman (1993). Kjeldahl nitrogen (TKN) was analyzed as described by Patton and Truitt (1992). During 1992-98, TP and DP were analyzed by means of a modified Kjeldahl procedure (Patton and Truitt, 2000). In 1999, these analyses were changed to follow USEPA method 365.1, low-level persulfate digestion (U.S. Environmental Protection Agency, 1993).

\section{Biological Sample Collection}

A biological sample was collected one time per site per year at the 54 sites used in this study between May and September, generally during periods of stable low flow, according to NAWQA methods as detailed below. Quantitative benthic algal samples (hereafter, algae samples) were collected from a defined area of substrate (rocks in riffle areas or submerged woody snags) to enable estimation of abundance per unit area and were composited into a single algae sample (Porter and others, 1993; Moulton and others, 2002). Algal taxa were identified at the Academy of Natural Sciences in Philadelphia, Pa. (Charles and others, 2002). Semiquantitative benthic-macroinvertebrate samples (hereafter, invertebrate samples) were collected from areas where maximum taxa richness was likely to occur, generally in the same habitats and locations as the areas sampled for algae, according to NAWQA methods (Cuffney and others, 1993; Moulton and others, 2002). Invertebrates were identified at the U.S. Geological Survey National Water Quality Laboratory, Lakewood, Colo. (Moulton and others, 2000). Fish were collected by field personnel using electrofishing units (backpack and towed-barge) and seines (Meador and others, 1993; Moulton and others, 2002). Fish were identified, weighed, and measured in the field and then returned to the stream. When species identification could not be confirmed in the field, several individuals of that species were vouchered, and their identification confirmed by taxonomists in the laboratory.

\section{Data Analysis}

This section details the statistical procedures used for data analysis of the nutrient and biological data. It includes descriptions of how nutrient and biological conditions at sites were determined and how breakpoints along a nutrient gradient were found for attributes of each biological community.

\section{Regional Differences}

For each of the three biological communities (algae, invertebrate, and fish), nonparametric statistical analyses were used to determine whether there was a regional difference between GNE and CWPE. By use of a Bray-Curtis similarity matrix based on squared-root-transformed community data, a non-metric multidimensional scaling (MDS) bi-plot configuration (Shepard, 1962; Kruskal, 1964a,b; Kruskal and Wish, 1978; Clarke and Warwick, 2001; Clarke and Gorley, 2006b) was created to depict the distribution of the sites. An analysis of similarity was done to determine whether it was possible to analyze ecoregions together or separately by testing the null hypothesis that the ecoregions are the same. 


\section{Nutrient Conditions of the Sites}

The water-quality data were summarized in three ways to assess which nutrient variables had the strongest relations with the biological data: the value on the date closest to the biological sample, the mean annual value, and mean annual maximum value. These three variables represent acute and chronic nutrient conditions that would affect the biological community. The water-quality data included the nitrogen and phosphorus nutrient variables $\mathrm{NO}_{2}+\mathrm{NO}_{3}$ as $\mathrm{N}, \mathrm{TN}$ as $\mathrm{N}, \mathrm{OP}$ as $\mathrm{P}$, and TP as $\mathrm{P}$; nutrient ratio variables that were used to assess nutrient limitation or the amount of dissolved nutrients (bioavailable) to total nutrients (long-term source) were $\mathrm{NO}_{3}$ to TKN, $\mathrm{NO}_{2}+\mathrm{NO}_{3}$ to TN, OP to TP, $\mathrm{NO}_{3}$ to OP, and TN to TP. A measure of algal biomass (chlorophyll $a$ or ash-free dry mass) would have greatly helped in assessing plant growth associated with the uptake component for the nutrient conditions at each sampling site. Specifically, the algal-biomass parameter could help assess whether low nutrient concentrations were due to oligotrophic conditions or whether algal uptake of nutrients accounted for the low concentrations. However, because few NAWQA study units collected algal biomass data during the 1990s, algal biomass measures were not included.

One approach of our study was to classify sites solely on the basis of instream nutrient concentrations and was based on the assumption that different biological communities would be found at sites with "low," "medium," and "high" nutrient concentrations. To maximize the gradient of nutrient concentrations for each ecoregion, sites were included for this part of the analysis based solely upon having at least six TN and TP samples collected throughout the year. A total of 64 sites, 27 sites in the GNE and 37 sites in the CWPE, had sufficient data to be included in this analysis (table 1).

"Low-nutrient" sites were those with concentrations at or below approximately the 10th percentile for TN and TP, "High-nutrient" sites were those approximately at or above the 75th percentile, and "Medium-nutrient" sites were between these two concentrations. The 10th percentile was used for "Low-nutrient" sites as a conservative target to assess reference-like conditions. Additionally, the 10th-percentile values for TN and TP were similar to proposed nutrient criteria for Nutrient Ecoregions VI, VII, and IX (U.S. Environmental Protection Agency, 2000d). Dodds and others (1998) used the 66th percentile as the eutrophic category, which was based solely on nutrient concentrations and not a measure of biological response; the 75th percentile was used in our study as a more conservative measure of the high-nutrient conditions. Multiple years of nutrient data were available for most NAWQA sampling sites. There were 54 sites where (1) at least 6 nutrient samples were collected per year, and (2) algal, invertebrate, and fish data were collected within the same year as the nutrient samples to describe the nutrient condition at these sites. Data from some of these intensively sampled sites spanned 13 years, including the period of widespread implementation of Best Management Practices designed to keep nutrients out of streams. All of the annual data for each site were included because changing nutrient concentrations at a site should be reflected by changes in species composition. To best represent the true nutrient condition of these streams, the median annual average concentration was used in the analyses, not the value from a low or high runoff year. Because some of the sites that had multiple years of nutrient data and annual average concentrations that spanned the 10th and 75th percentiles (low, medium, and (or) high categories), the percentile values were adjusted up or down slightly so that sites would be included only in one nutrient category. The final low, medium, and high concentrations for TN and TP in the CWPE and GNE diatom ecoregions are listed in table 2.

Table 2. Nutrient categories for total nitrogen and total phosphorus in the Central and Western Plains and Glaciated North diatom ecoregions.

[mg/L, milligrams per liter; <, less than; >, greater than]

\begin{tabular}{cccc}
\hline \multirow{2}{*}{ Nutrient } & \multicolumn{3}{c}{ Now } \\
\cline { 2 - 4 } & sites & $\begin{array}{c}\text { Medium } \\
\text { sites }\end{array}$ & $\begin{array}{c}\text { High } \\
\text { sites }\end{array}$ \\
\hline \multicolumn{4}{c}{ Central and Western Plains diatom ecoregion (CWPE) } \\
\hline Total nitrogen (mg/L) & $<1.74$ & $1.74-7.80$ & $>7.80$ \\
Total phosphorus (mg/L) & $<.05$ & $.05-.17$ & $>.17$ \\
\hline \multicolumn{4}{c}{ Glaciated North diatom ecoregion (GNE) } \\
\hline Total nitrogen (mg/L) & $<0.60$ & $0.60-2.08$ & $>2.08$ \\
Total phosphorus (mg/L) & $<.01$ & $.01-.13$ & $>.13$ \\
\hline
\end{tabular}

\section{Biological Conditions of the Sites}

All biological data were retrieved from either the USGS NAWQA biological database (BioTDB, for algae) or Data Warehouse (U.S. Geological Survey, 2007, 2008, for fish and invertebrates). Biological samples were checked for possible errors on the basis of species richness, biovolume, and individual richness. Biological communities and attributes were summarized and computed by using the Algal Data Analysis System (ADAS) for algae and the Invertebrate Data Analysis System (IDAS) for invertebrates. IDAS was developed to reduce ambiguous taxa and calculation of tolerance, feeding guild, water-quality preference, and other assemblage attributes (Cuffney, 2003). ADAS is a similar program, modified for algal communities. Fish attributes were calculated by use of Microsoft Excel. Statistical analysis of biological, nutrient and environmental data was done with PRIMER version 6.1.10 (Clarke and Warwick, 2001; Clarke and Gorley, 2006a, b) and S-Plus version 8.1 (TIBCO, 2008).

A total of 566 algal species were identified at the 54 sites; this taxa list was used to calculate the algal attributes, including oxygen requirements, pollution tolerance, nutrient trophic preference, saprobic condition, and $\mathrm{pH}$ preference. 
Table 1. Location, drainage area, diatom ecoregion, and period-of-record data of the 64 sampling sites in the Central and Western Plains and Glacial North diatom ecoregions.

[km², square kilometer; CWPE, Central and Western Plains diatom ecoregion; GNE, Glacial North diatom ecoregion; Med, medium; NA, no biological data]

\begin{tabular}{|c|c|c|c|c|c|c|c|c|c|c|}
\hline $\begin{array}{c}\text { Site } \\
\text { number }\end{array}$ & $\begin{array}{c}\text { Station } \\
\text { identification }\end{array}$ & $\begin{array}{c}\text { Station } \\
\text { name }\end{array}$ & Latitude & Longitude & $\begin{array}{c}\text { Drainage } \\
\text { area } \\
\left(\mathbf{k m}^{2}\right)\end{array}$ & $\begin{array}{l}\text { Diatom } \\
\text { ecoregion }\end{array}$ & $\begin{array}{c}\text { Used for } \\
\text { the } \\
\text { biological } \\
\text { analyses }\end{array}$ & $\begin{array}{c}\text { Number of } \\
\text { nutrient } \\
\text { samples } \\
\text { per site }\end{array}$ & $\begin{array}{c}\text { Years of } \\
\text { nutrient } \\
\text { data }\end{array}$ & $\begin{array}{c}\text { Years of } \\
\text { biological } \\
\text { data }\end{array}$ \\
\hline 1 & 04186500 & $\begin{array}{l}\text { AUGLAIZE RIVER NEAR } \\
\text { FORT JENNINGS, OH }\end{array}$ & 40.94866 & -84.26606 & 858.4 & CWPE & YES & 92 & $\begin{array}{l}\text { 1996-98, } \\
\text { 2001-04 }\end{array}$ & $\begin{array}{l}1996, \\
2002-04\end{array}$ \\
\hline A & 393306086585201 & $\begin{array}{l}\text { BIG WALNUT CREEK AT CO RD } 700 \mathrm{~W} \\
\text { AT REELSVILLE, IN }\end{array}$ & 39.55171 & -86.98110 & 823.6 & CWPE & NO & 31 & 1993-94 & NA \\
\hline 2 & 03357330 & $\begin{array}{l}\text { BIG WALNUT CREEK NEAR } \\
\text { ROACHDALE, IN }\end{array}$ & 39.81616 & -86.75334 & 340.1 & CWPE & YES & 33 & 2002-04 & 2002-04 \\
\hline 3 & 040853145 & $\begin{array}{l}\text { BLACK CREEK AT CURRAN ROAD } \\
\text { NEAR DENMARK, WI }\end{array}$ & 44.33722 & -87.74537 & 56.1 & GNE & YES & 6 & 2004 & 2004 \\
\hline 4 & 04159492 & BLACK RIVER NEAR JEDDO, MI & 43.15253 & -82.62409 & $1,197.8$ & CWPE & YES & 29 & 1996-97 & 1996 \\
\hline 5 & 04213500 & CATTARAUGUS CR AT GOWANDA, NY & 42.46395 & -78.93503 & $1,128.8$ & GNE & YES & 26 & 1996-97 & 1996 \\
\hline 6 & 05286290 & $\begin{array}{l}\text { CEDAR CREEK NEAR } \\
\text { COOPERS CORNER, MN }\end{array}$ & 45.39191 & -93.21245 & 70.7 & GNE & YES & 6 & 1996 & 1996 \\
\hline $\mathrm{B}$ & 05536995 & $\begin{array}{l}\text { CHICAGO SANITARY AND SHIP CANAL } \\
\text { AT ROMEOVILLE, IL }\end{array}$ & 41.64059 & -88.06060 & $1,852.0$ & CWPE & NO & 33 & $\begin{array}{l}1992,1999- \\
2000\end{array}$ & NA \\
\hline $\mathrm{C}$ & 391732085414401 & $\begin{array}{l}\text { CLIFTY CREEK AT CO RD } 1150 \text { E } \\
\text { NEAR HARTSVILLE, IN }\end{array}$ & 39.29227 & -85.69550 & 227.6 & CWPE & NO & 35 & 1993-94 & NA \\
\hline 7 & 04161820 & $\begin{array}{l}\text { CLINTON RIVER AT } \\
\text { STERLING HEIGHTS, MI }\end{array}$ & 42.61448 & -83.02659 & 802.8 & GNE & YES & 83 & $\begin{array}{l}\text { 1996-97, } \\
2001-05\end{array}$ & $\begin{array}{l}1996-97 \\
2001-05\end{array}$ \\
\hline 8 & 04208504 & $\begin{array}{l}\text { CUYAHOGA RIVER NEAR NEWBURGH } \\
\text { HEIGHTS, OH }\end{array}$ & 41.46255 & -81.68096 & $2,043.6$ & GNE & YES & 33 & $1996-97$ & 1996 \\
\hline 9 & 05532500 & DES PLAINES RIVER AT RIVERSIDE, IL & 41.82225 & -87.82089 & $1,634.2$ & CWPE & YES & 74 & $\begin{array}{l}1992,1999- \\
2004\end{array}$ & $\begin{array}{l}1999, \\
2002-04\end{array}$ \\
\hline 10 & 05527800 & DES PLAINES RIVER AT RUSSELL, IL & 42.48919 & -87.92647 & 317.7 & CWPE & YES & 39 & 1999-2001 & 1999-2001 \\
\hline 11 & 04072050 & $\begin{array}{l}\text { DUCK CREEK AT SEMINARY ROAD } \\
\text { NEAR ONEIDA, WI }\end{array}$ & 44.46582 & -88.21899 & 247.2 & GNE & YES & 111 & $\begin{array}{l}\text { 1993-95, } \\
\text { 2002-04 }\end{array}$ & $\begin{array}{c}1993-95 \\
1997-98 \\
2002-04\end{array}$ \\
\hline $\mathrm{D}$ & 04072150 & DUCK CREEK NEAR HOWARD, WI & 44.53583 & -88.12972 & 247.2 & GNE & NO & 95 & $\begin{array}{l}1995,1997- \\
2001\end{array}$ & NA \\
\hline 12 & 03246400 & $\begin{array}{l}\text { EAST FORK LITTLE MIAMI RIVER } \\
\text { NEAR WILLIAMSBURG, OH }\end{array}$ & 39.05895 & -84.05132 & 606.5 & CWPE & YES & 19 & $1999-2000$ & 1999 \\
\hline $\mathrm{E}$ & 04085108 & $\begin{array}{l}\text { EAST RIVER AT CT HIGHWAY ZZ } \\
\text { NEAR GREENLEAF, WI }\end{array}$ & 44.38667 & -88.07972 & 122.2 & GNE & NO & 14 & 1994 & NA \\
\hline
\end{tabular}


Table 1. Location, drainage area, diatom ecoregion, and period-of-record data of the 64 sampling sites in the Central and Western Plains and Glacial North diatom ecoregions.-Continued

[km², square kilometer; CWPE, Central and Western Plains diatom ecoregion; GNE, Glacial North diatom ecoregion; Med, medium; NA, no biological data]

\begin{tabular}{|c|c|c|c|c|c|c|c|c|c|c|}
\hline $\begin{array}{l}\text { Site } \\
\text { number }\end{array}$ & $\begin{array}{c}\text { Station } \\
\text { identification }\end{array}$ & $\begin{array}{l}\text { Station } \\
\text { name }\end{array}$ & Latitude & Longitude & $\begin{array}{c}\text { Drainage } \\
\text { area } \\
\left(\mathbf{k m}^{2}\right)\end{array}$ & $\begin{array}{c}\text { Diatom } \\
\text { ecoregion }\end{array}$ & $\begin{array}{l}\text { Used for } \\
\text { the } \\
\text { biological } \\
\text { analyses }\end{array}$ & $\begin{array}{c}\text { Number of } \\
\text { nutrient } \\
\text { samples } \\
\text { per site }\end{array}$ & $\begin{array}{c}\text { Years of } \\
\text { nutrient } \\
\text { data }\end{array}$ & $\begin{array}{l}\text { Years of } \\
\text { biological } \\
\text { data }\end{array}$ \\
\hline 13 & 04085109 & $\begin{array}{l}\text { EAST RIVER AT MIDWAY ROAD } \\
\text { NEAR DE PERE, WI }\end{array}$ & 44.38666 & -88.07982 & 122.2 & GNE & YES & 26 & 1993-95 & $1993-95$ \\
\hline $\mathrm{F}$ & 04075365 & $\begin{array}{l}\text { EVERGREEN RIVER BLW EVERGREEN } \\
\text { FALLS NR LANGLADE, WI }\end{array}$ & 45.06583 & -88.67611 & 161.6 & GNE & NO & 31 & 2003-04 & NA \\
\hline G & 04177810 & FISH CREEK NEAR ARTIC, IN & 41.46500 & -84.81417 & 256.4 & CWPE & NO & 9 & 1998 & NA \\
\hline 14 & 05461390 & FLOOD CREEK NEAR POWERSVILLE, IA & 42.90720 & -92.72075 & 321.2 & CWPE & YES & 35 & 1996-97 & 1996-97 \\
\hline 15 & 04211820 & GRAND RIVER AT HARPERSFIELD, OH & 41.75533 & -80.94843 & $1,431.5$ & GNE & YES & 33 & 1996-97 & 1996-97 \\
\hline 16 & 393944084120700 & $\begin{array}{l}\text { HOLES CK IN HUFFMAN PARK AT } \\
\text { KETTERING, OH }\end{array}$ & 39.66228 & -84.20188 & 51.9 & CWPE & YES & 121 & 1999-2004 & $1999-2004$ \\
\hline 17 & 05568800 & INDIAN CREEK NEAR WYOMING, IL & 41.01889 & -89.83556 & 163.7 & CWPE & YES & 29 & $1997-98$ & $1997-98$ \\
\hline 18 & 05449500 & IOWA RIVER NEAR ROWAN, IA & 42.75994 & -93.62185 & 1083.9 & CWPE & YES & 92 & $\begin{array}{l}\text { 1996-98, } \\
2001-04\end{array}$ & $\begin{array}{l}\text { 1996-98, } \\
2002-04\end{array}$ \\
\hline 19 & 03360895 & $\begin{array}{l}\text { KESSINGER DITCH NEAR } \\
\text { MONROE CITY, IN }\end{array}$ & 38.57060 & -87.27696 & 145.6 & CWPE & YES & 55 & 1993-95 & 1993 \\
\hline 20 & 05584500 & LA MOINE RIVER AT COLMAR, IL & 40.33032 & -90.89625 & 1695.7 & CWPE & YES & 73 & $1997-98$ & 1997-98 \\
\hline 21 & 05320270 & $\begin{array}{l}\text { LITTLE COBB RIVER NEAR } \\
\text { BEAUFORD, MN }\end{array}$ & 43.99663 & -93.90856 & 336.0 & CWPE & YES & 103 & $\begin{array}{l}\text { 1996-99, } \\
\text { 2001-05 }\end{array}$ & $\begin{array}{l}\text { 1996-97, } \\
\text { 2002-04 }\end{array}$ \\
\hline 22 & 03373530 & LOST RIVER NEAR LEIPSIC, IN & 38.63644 & -86.36526 & 90.1 & CWPE & YES & 31 & 1993-94 & 1993 \\
\hline 23 & 03267900 & $\begin{array}{l}\text { MAD RIVER AT ST PARIS PIKE AT } \\
\text { EAGLE CITY, OH }\end{array}$ & 39.96423 & -83.83160 & 802.9 & CWPE & YES & 118 & 1999-2004 & $1999-2004$ \\
\hline 24 & 04087000 & MILWAUKEE RIVER AT MILWAUKEE, WI & 43.10001 & -87.90897 & 1805.2 & GNE & YES & 144 & $\begin{array}{c}1993-95 \\
1997- \\
2004\end{array}$ & $\begin{array}{l}1995, \\
1997-98, \\
2002-04\end{array}$ \\
\hline 25 & 03366500 & $\begin{array}{l}\text { MUSCATATUCK RIVER NEAR } \\
\text { DEPUTY, IN }\end{array}$ & 38.80422 & -85.67386 & 758.9 & CWPE & YES & 28 & 1993-94 & 1993 \\
\hline 26 & 05331833 & NAMEKAGON RIVER AT LEONARDS, WI & 46.17134 & -91.32935 & 332.6 & GNE & YES & 32 & 1996-97 & 1996-97 \\
\hline 27 & 05330902 & $\begin{array}{l}\text { NINE MILE CREEK NEAR JAMES CIRCLE } \\
\text { AT BLOOMINGTON, MN }\end{array}$ & 44.80719 & -93.30161 & 115.5 & GNE & YES & 54 & 1996-97 & 1996-97 \\
\hline 28 & 05548105 & $\begin{array}{l}\text { NIPPERSINK CREEK ABOVE } \\
\text { WONDER LAKE, IL }\end{array}$ & 42.38530 & -88.36954 & 219.4 & CWPE & YES & 38 & 1999-2001 & 1999-2001 \\
\hline 29 & 040863075 & $\begin{array}{l}\text { NORTH BRANCH MILWAUKEE RIVER } \\
\text { NEAR RANDOM LAKE, WI }\end{array}$ & 43.55694 & -88.05287 & 129.9 & GNE & YES & 52 & $\begin{array}{c}1993-95 \\
2001\end{array}$ & 1993-95 \\
\hline
\end{tabular}


Table 1. Location, drainage area, diatom ecoregion, and period-of-record data of the 64 sampling sites in the Central and Western Plains and Glacial North diatom ecoregions.-Continued

[km², square kilometer; CWPE, Central and Western Plains diatom ecoregion; GNE, Glacial North diatom ecoregion; Med, medium; NA, no biological data]

\begin{tabular}{|c|c|c|c|c|c|c|c|c|c|c|}
\hline $\begin{array}{c}\text { Site } \\
\text { number }\end{array}$ & $\begin{array}{c}\text { Station } \\
\text { identification }\end{array}$ & $\begin{array}{c}\text { Station } \\
\text { name }\end{array}$ & Latitude & Longitude & $\begin{array}{c}\text { Drainage } \\
\text { area } \\
\left(\mathbf{k m}^{2}\right)\end{array}$ & $\begin{array}{l}\text { Diatom } \\
\text { ecoregion }\end{array}$ & $\begin{array}{c}\text { Used for } \\
\text { the } \\
\text { biological } \\
\text { analyses }\end{array}$ & $\begin{array}{c}\text { Number of } \\
\text { nutrient } \\
\text { samples } \\
\text { per site }\end{array}$ & $\begin{array}{c}\text { Years of } \\
\text { nutrient } \\
\text { data }\end{array}$ & $\begin{array}{c}\text { Years of } \\
\text { biological } \\
\text { data }\end{array}$ \\
\hline 30 & 05276005 & $\begin{array}{l}\text { NORTH FORK CROW RIVER ABOVE } \\
\text { PAYNESVILLE, MN }\end{array}$ & 45.37719 & -94.78362 & 601.4 & GNE & YES & 35 & $1996-97$ & $1996-97$ \\
\hline 31 & 04087204 & OAK CREEK AT SOUTH MILWAUKEE, WI & 42.92502 & -87.87008 & 66.8 & GNE & YES & 33 & 2003-04 & 2004 \\
\hline 32 & 05455100 & OLD MANS CREEK NEAR IOWA CITY, IA & 41.60641 & -91.61572 & 521.8 & CWPE & YES & 43 & 1996-98 & $1996-97$ \\
\hline 33 & 05030150 & OTTER TAIL RIVER NEAR PERHAM, MN & 46.64274 & -95.60449 & 870.1 & GNE & YES & 24 & 1993-95 & 1994 \\
\hline 34 & 05567000 & PANTHER CREEK NEAR EL PASO, IL & 40.77333 & -89.07694 & 243.4 & CWPE & YES & 29 & $1997-98$ & $1997-98$ \\
\hline 35 & 04071795 & PENSAUKEE RIVER NEAR KRAKOW, WI & 44.75249 & -88.27649 & 86.8 & GNE & YES & 34 & 1993-94 & 1993-94 \\
\hline 36 & 04062085 & $\begin{array}{l}\text { PESHEKEE RIVER NEAR } \\
\text { MARTINS LANDING, MI }\end{array}$ & 46.60966 & -88.02235 & 114.4 & GNE & YES & 33 & 1993-94 & 1993-94 \\
\hline $\mathrm{H}$ & 04066500 & PIKE RIVER AT AMBERG, WI & 45.50000 & -88.00000 & 639.1 & GNE & NO & 27 & 2003-04 & NA \\
\hline 37 & 04087258 & $\begin{array}{l}\text { PIKE RIVER AT CTH A NEAR } \\
\text { KENOSHA, WI }\end{array}$ & 42.65363 & -87.85035 & 100.3 & CWPE & YES & 9 & 2004 & 2004 \\
\hline 38 & 04063700 & POPPLE RIVER NEAR FENCE, WI & 45.76357 & -88.46318 & 362.6 & GNE & YES & 87 & $\begin{array}{l}1993-95 \\
2001-05\end{array}$ & $\begin{array}{l}1993-95 \\
2002-05\end{array}$ \\
\hline 39 & 04085188 & $\begin{array}{l}\text { RIO CREEK AT PHEASANT ROAD } \\
\text { NEAR RIO CREEK, WI }\end{array}$ & 44.60333 & -87.52703 & 55.8 & GNE & YES & 6 & 2004 & 2004 \\
\hline 40 & 04175600 & RIVER RAISIN NEAR MANCHESTER, MI & 42.16809 & -84.07606 & 330.8 & GNE & YES & 61 & $\begin{array}{l}\text { 1996-97, } \\
\text { 2001-04 }\end{array}$ & $\begin{array}{l}1996, \\
2002-04\end{array}$ \\
\hline 41 & 05531500 & SALT CREEK AT WESTERN SPRINGS, IL & 41.82583 & -87.90028 & 290.6 & CWPE & YES & 92 & $1999-2005$ & $\begin{array}{l}1999, \\
2002-05\end{array}$ \\
\hline 42 & 05572000 & SANGAMON RIVER AT MONTICELLO, IL & 40.03087 & -88.58895 & 1426.5 & CWPE & YES & 117 & $\begin{array}{l}\text { 1997-98, } \\
2001-05\end{array}$ & $\begin{array}{l}1997-98 \\
2002-05\end{array}$ \\
\hline 43 & 05288705 & $\begin{array}{l}\text { SHINGLE CREEK AT QUEEN AVE IN } \\
\text { MINNEAPOLIS, MN }\end{array}$ & 45.04997 & -93.31023 & 73.0 & GNE & YES & 120 & $\begin{array}{l}1996-99 \\
2001-05\end{array}$ & $\begin{array}{l}\text { 1996-98, } \\
2002-05\end{array}$ \\
\hline I & 05085900 & SNAKE RIVER ABOVE ALVARADO, MN & 48.17415 & -96.99900 & 564.6 & CWPE & NO & 28 & 1993-94 & NA \\
\hline $\mathrm{J}$ & 05086000 & SNAKE RIVER AT ALVARADO, MN & 48.17417 & -96.99861 & 800.3 & CWPE & NO & 6 & 1993 & NA \\
\hline 44 & 05451210 & $\begin{array}{l}\text { SOUTH FORK IOWA RIVER NE OF } \\
\text { NEW PROVIDENCE, IA }\end{array}$ & 42.31498 & -93.15243 & 580.5 & CWPE & YES & 107 & $1996-2005$ & $\begin{array}{l}\text { 1996-97, } \\
2002-05\end{array}$ \\
\hline 45 & 04178000 & ST JOSEPH RIVER NEAR NEWVILLE, IN & 41.38561 & -84.80163 & 1600.2 & CWPE & YES & 88 & $\begin{array}{l}\text { 1996-98, } \\
2001-04\end{array}$ & $\begin{array}{l}1996, \\
2002-04\end{array}$ \\
\hline 46 & 395355084173600 & $\begin{array}{l}\text { STILLWATER R. ON MARTINDALE R. } \\
\text { NEAR UNION, OH }\end{array}$ & 39.89867 & -84.29328 & 1673.1 & CWPE & YES & 30 & $1999-2000$ & 1999 \\
\hline
\end{tabular}


Table 1. Location, drainage area, diatom ecoregion, and period-of-record data of the 64 sampling sites in the Central and Western Plains and Glacial North diatom ecoregions.-Continued

$\left[\mathrm{km}^{2}\right.$, square kilometer; CWPE, Central and Western Plains diatom ecoregion; GNE, Glacial North diatom ecoregion; Med, medium; NA, no biological data]

\begin{tabular}{|c|c|c|c|c|c|c|c|c|c|c|}
\hline $\begin{array}{l}\text { Site } \\
\text { number }\end{array}$ & $\begin{array}{c}\text { Station } \\
\text { identification }\end{array}$ & $\begin{array}{l}\text { Station } \\
\text { name }\end{array}$ & Latitude & Longitude & $\begin{array}{c}\text { Drainage } \\
\text { area } \\
\left(\mathrm{km}^{2}\right)\end{array}$ & $\begin{array}{l}\text { Diatom } \\
\text { ecoregion }\end{array}$ & $\begin{array}{l}\text { Used for } \\
\text { the } \\
\text { biological } \\
\text { analyses }\end{array}$ & $\begin{array}{c}\text { Number of } \\
\text { nutrient } \\
\text { samples } \\
\text { per site }\end{array}$ & $\begin{array}{c}\text { Years of } \\
\text { nutrient } \\
\text { data }\end{array}$ & $\begin{array}{l}\text { Years of } \\
\text { biological } \\
\text { data }\end{array}$ \\
\hline 47 & 394340085524601 & $\begin{array}{l}\text { SUGAR CREEK AT CO RD } 400 \mathrm{~S} \text { AT } \\
\text { NEW PALESTINE, IN }\end{array}$ & 39.72782 & -85.87942 & 246.2 & CWPE & YES & 289 & $1992-2005$ & $\begin{array}{l}1998, \\
2002-05\end{array}$ \\
\hline 48 & 05525500 & SUGAR CREEK AT MILFORD, IL & 40.63004 & -87.72392 & 1158.8 & CWPE & YES & 75 & 1999-2004 & $\begin{array}{l}1999, \\
2002-04\end{array}$ \\
\hline 49 & 04080798 & $\begin{array}{l}\text { TOMORROW RIVER NEAR } \\
\text { NELSONVILLE, WI }\end{array}$ & 44.52442 & -89.33789 & 114.0 & GNE & YES & 32 & $1993-94$ & 1993-94 \\
\hline 50 & 05082625 & $\begin{array}{l}\text { TURTLE R AT TURTLE R STATE PARK } \\
\text { NEAR ARVILLA, ND }\end{array}$ & 47.93832 & -97.50036 & 311.0 & GNE & YES & 83 & $\begin{array}{c}1993-94 \\
1996- \\
2000\end{array}$ & $\begin{array}{c}1993-94, \\
1997\end{array}$ \\
\hline 51 & 05420680 & WAPSIPINICON RIVER NEAR TRIPOLI, IA & 42.83609 & -92.25740 & 897.0 & CWPE & YES & 76 & $\begin{array}{l}\text { 1996-98, } \\
2001-04\end{array}$ & $\begin{array}{l}\text { 1996-97, } \\
\text { 2002-04 }\end{array}$ \\
\hline 52 & 03275000 & WHITEWATER RIVER NEAR ALPINE, IN & 39.57310 & -85.15746 & 1370.1 & CWPE & YES & 27 & $1999-2000$ & 1999 \\
\hline 53 & 05062500 & WILD RICE RIVER AT TWIN VALLEY, MN & 47.26663 & -96.24478 & 2407.1 & CWPE & YES & 48 & $1993-96$ & $1993-95$ \\
\hline 54 & 05464220 & WOLF CREEK NEAR DYSART, IA & 42.25166 & -92.29880 & 775.2 & CWPE & YES & 55 & 1996-98 & $1996-98$ \\
\hline
\end{tabular}


The original taxa list was then reduced by removing rare taxa: those that occurred in three or fewer samples and at less than 3 percent of the summed relative abundance for all samples. This reduction resulted in 448 species used for community analysis: 334 diatom species, 70 blue-green algae species, 33 green algae species, 5 euglenoid species, 4 red algae species, and 2 species with an undetermined algal division. Many of the benthic algal attributes focused on a large and diverse group of single-celled algae called "diatoms" and that means the diatoms discussed are "benthic" diatoms. Algal attributes based on species attributes, such as dissolved oxygen (DO) requirements, nutrient preferences, nitrogen fixation, and motility, among others, were calculated for individual abundance, richness, and relative percentages of both (Lange-Bertalot, 1979; Bahls, 1993; Van Dam and others, 1994; Porter, 2008).

A total of 481 invertebrate taxa were found at the 54 sites after ambiguous taxa were divided among the children of the parent taxa on the basis of relative composition (Cuffney, 2003). Functional feeding-group and regional-tolerance attributes, based on this taxa list, were derived from appendix B of the USEPA's Rapid Bioassessment Protocol (RBP) included in the Invertebrate Data Analysis System (IDAS) program (Barbour and others, 1999; Cuffney, 2003). Similar to the algal assemblage, the original taxa list was then reduced by removing rare taxa (those that occurred in three or fewer samples and at less than 3 percent of the summed relative abundance for all samples). The reduction resulted in a final taxa list of 260 species.

A total of 159 fish species for all 54 sites were identified. Because of the relatively small species list compared to the algae and invertebrates, no rare taxa were removed for fishcommunity attributes, and all analyses were completed on the full taxa list. Fish-community attributes were based on species traits such as preferences for substrate, geomorphic units, trophic ecology, feeding guild, stream size, locomotion, and reproductive strategy. Additionally, commonly used attributes from fish Indices of Biotic Integrity (IBI) in the Midwest were included, such as number of individuals (abundance) and taxa (richness) and abundance of certain families (Karr and others, 1986; Lyons, 1992; Barbour and others, 1999; Goldstein and Meador, 2004).

\section{Using Biological and Nutrient Conditions to Describe Differences between Sites}

The calculation of the biological attributes resulted in a large number of variables for use in further data analysis; however, because of the number of samples in our dataset, the list of over 400 attributes needed to be reduced to a manageable number. The goal in reducing the variable set was to identify the fewest attributes that distinguish different responses to the same environmental stressors - in this case, nutrients. For example, the number of individuals or taxa may increase with increasing nutrients, but the number of sensitive or intolerant species may decrease. The first task in attribute reduction was grouping the variables for each community into logical categories such as trophic level (fish), feeding group (invertebrates), nutrient/eutrophic preference (algae), and pollution tolerance (all). Secondly, Spearman rank correlations between the attributes were examined within each biological category to select attributes that were not strongly correlated with each other. For example, there may be a strong relation of motile algae to nonmotile algae, but it would be redundant to retain both attributes because they are the inverse of each other; so, only one of the attributes was retained.

The third step in biological-attribute reduction was examining the Spearman rank correlation between the retained biological attributes and the different nutrient variables $\left(\mathrm{NO}_{2}+\mathrm{NO}_{3}-\mathrm{N}, \mathrm{TN}, \mathrm{OP}, \mathrm{TP}, \mathrm{NO}_{3}: \mathrm{TKN}, \mathrm{NO}_{3}: \mathrm{TN}, \mathrm{OP}: \mathrm{TP}\right.$, $\mathrm{NO}_{3}: \mathrm{OP}$, and TN:TP, based on annual, maximum, and nearestbiological-sample values). Several biological attributes within each community showed strong linear relations to the nutrient variables. The last step in biological-attributes reduction was to examine the attributes on the basis of correlation values with nutrients, relations found in previous studies, and best professional judgment in selecting attributes that were believed to provide the best ecologically-based response.

An ordination, which is a nonparametric, multivariate analysis, was used to determine which species were most related to the distribution of the sites (Clarke and Ainsworth, 1993). Basically, MDS plots were used to display the similarity or difference between samples as revealed by a stepwise regression to examine which species within each biological assemblage and ecoregion account for those similarities or differences by maximizing a rank correlation between the biological assemblage and the resemblance matrix. For example, if sites A and B are relatively close together on the MDS plot, they have similar species composition, whereas if site $\mathrm{C}$ is distant from sites $\mathrm{A}$ and $\mathrm{B}$, the $\mathrm{x}$ species composition differs correspondingly. The species common between $\mathrm{A}$ and $\mathrm{B}$ and not for $\mathrm{C}$ are identified by using this technique. Once the species with the highest rank correlation to the site distribution is identified, the species with the next highest correlation is identified and combined with correlation of the first species. This additive, stepwise process is repeated for all species until either the addition of species does not enhance the correlation statistic or a list of the 10 species with the highest rank correlations is identified. The list of species is assumed to be responsible for the majority of the distribution of sites. This process was repeated using the biological attributes for each assemblage to determine which selected biological attributes were most related to the site distribution.

A similar analysis was done to determine which nutrient variables most closely represent the biological assemblages for each of the community assemblages for both diatom ecoregions, individually and combined. The resemblance matrices for the nutrient data were calculated by using Euclidean distance. The nutrient variable or combination of variables most related to the similarities of the biological data was determined by the stepwise comparison. It was assumed that these 
variables, attributes, and species represent the most significant ecological and nutrient relations.

Use of the biological communities to evaluate nutrient categories was a multistep process, the first step being a modification of multivariate regression tree analysis developed by De'ath (2002). The procedure takes abiotic variables (in this case the nutrient concentrations) and uses them to "describe how best the [biological] assemblages are split into groups by successive binary division" (Clarke and Gorley, 2006b). Secondly, to assess the differences in the biological communities between the low, medium, and high nutrient sites, a similarity analysis was done for the algal-, invertebrate-, and fish-community data.

The goal of breakpoint or change-point analysis is to identify the concentration at which the relations between the response variable and the stressor variable (TN and TP) change. The form of the change in relation can be any of a wide variety of changes - change in mean, change in variance, change in slope, and so forth. The procedures described in this section were developed by using Spotfire $\mathrm{S}+{ }^{\circledR}$ (TIBCO, 2008) and using the resample library for the bootstrapping and permutation methods.

The deviance-reduction method of breakpoint analysis was used in this study. This method sorts observations along the stressor-variable gradient and identifies the concentration where the deviance is minimized (Qian and others, 2003). The method is based on tree-based modeling (Breiman and others, 1984) and selects the first binary split as the change point. The deviance is the sum of the squared differences between the response variable and the respective mean for all observations less than or equal to the breakpoint and all observations greater than the breakpoint, as follows (equation 1):

$$
D_{k}=\sum_{i=1}^{k}\left(y_{i}-\mu_{k-}\right)^{2}+\sum_{j=k+1}^{n}\left(y_{j}-\mu_{k+}\right)^{2}
$$

where

$$
\begin{array}{cl}
D_{k} & \begin{array}{c}
\text { is the deviance computed for observation, } \\
\text { are response variables, }
\end{array} \\
\text { ind } y_{j} & \begin{aligned}
\text { is the mean of response variables less than or } \\
\text { equal to } k \text {, and }
\end{aligned} \\
\mu_{k+} & \begin{array}{l}
\text { is the mean of response variables greater } \\
\text { than } k .
\end{array}
\end{array}
$$

The method divides the observations into two groups, which are assumed to be relatively homogenous (Qian and others, 2003). To reduce the effect of influential observations near the ends of the range of the stressor variables, a minimum group size of 8 was used for all analyses.

The deviance-reduction method will always find a minimum deviance and an associated breakpoint regardless of the real ecological change. The achieved significance level (ASL) of the minimum deviance is computed by using a permutation test (Efron and Tibshirani, 1993). The permutation test permutes the values of the response variable many times, 999 times for this study, and computes the minimum deviance from each permutation. The ASL is computed as the number of the simulated minimum deviances less than the observed value plus 1 divided by the total number of simulations (permutation) plus 1 (equation 2) and is treated much like a $\mathrm{p}$-value from a parametric significance test:

$$
A S L=(N+1) /(B+1)
$$

where

$$
\begin{gathered}
N \quad \begin{array}{c}
\text { is the number of the simulated minimum } \\
\text { deviances less than the observed value and }
\end{array} \\
B \quad \text { is the total number of simulations. }
\end{gathered}
$$

Parametric tests have been used in other breakpoint-analysis software applications (Tetra Tech, 2009), under the assumption that the parametric distribution is approximately correct, but simulations done for this study indicate that substantial differences can occur.

An estimate of the error of the breakpoint estimate can be obtained by bootstrapping methods (Qian and others, 2003). A specialized sampling method was developed to preserve the range of the stressor variable and the local behavior of the environmental-response variable. The method is called random block resampling. In contrast to block resampling, which divides the set of observations into known blocks that are resampled, random block resampling creates blocks of observations along a specific gradient that vary in size for each simulation. The response variable is resampled with replacement in each block for each value of the stressor variable. The average group size used for this study was about 4 .

The following example can help describe the random block resampling method. Consider eight samples with values of 1 though 8 for the stressor variable and values of 11 though 18 the corresponding response variable. The first step is to select observations along the environmental gradient that divides the observations into a known number of groups. For this example, one observation will be selected to subdivide the data into two groups. Assume that it is observation number 5, which creates groups of 1 through 5 and 6 through 8 . The response variables are also grouped 11 through 15 and 16 through 18. For each stressor value in the first group, one value from the first group of response values is selected. For this example, the selections could be $12,14,11,12,13$. The same procedure is repeated for each group. The selection for the second group could be 16,17, and 16. These data would be analyzed to determine the breakpoint and the method repeated several times to create a sample of possible breakpoint values. The simulations can be used to estimate the uncertainty in the change point. Plots of the counts of simulated change points can be useful in indentifying other problems such as alternate change points indicated by bimodal density. 


\section{Description of Regional Differences and the Nutrient and Biological Conditions in the Nutrient Categories}

\section{Regional Biological Differences}

Potapova and Charles (2007) divided the MRB3 region into the GNE and CWPE because of significant differences in the algal community. Ordination analysis showed all three biological communities were significantly different, with the fish community showing the most dissimilarity between the two diatom ecoregions (fig. 3).
As indicated by the ordination analysis and confirmed by an analysis of similarities (table 3), the community assemblages in the GNE and CWPE diatom ecoregions are significantly dissimilar and therefore should be analyzed separately. There was a significant dissimilarity between GNE and EHE invertebrate and fish communities but no such dissimilarity for the algae communities. Because only two sites were in the EHE and the land use, nutrient concentrations, algal and fish communities and general location were more like those in the CWPE than the GNE, those two sites were included in the analysis of the CWPE. MDS ordinations were recreated separately for the two diatom ecoregions (GNE and CWPE) for each biological community. The ordination scores derived from these diatom-ecoregion-scaled MDS were included in the biological attributes.

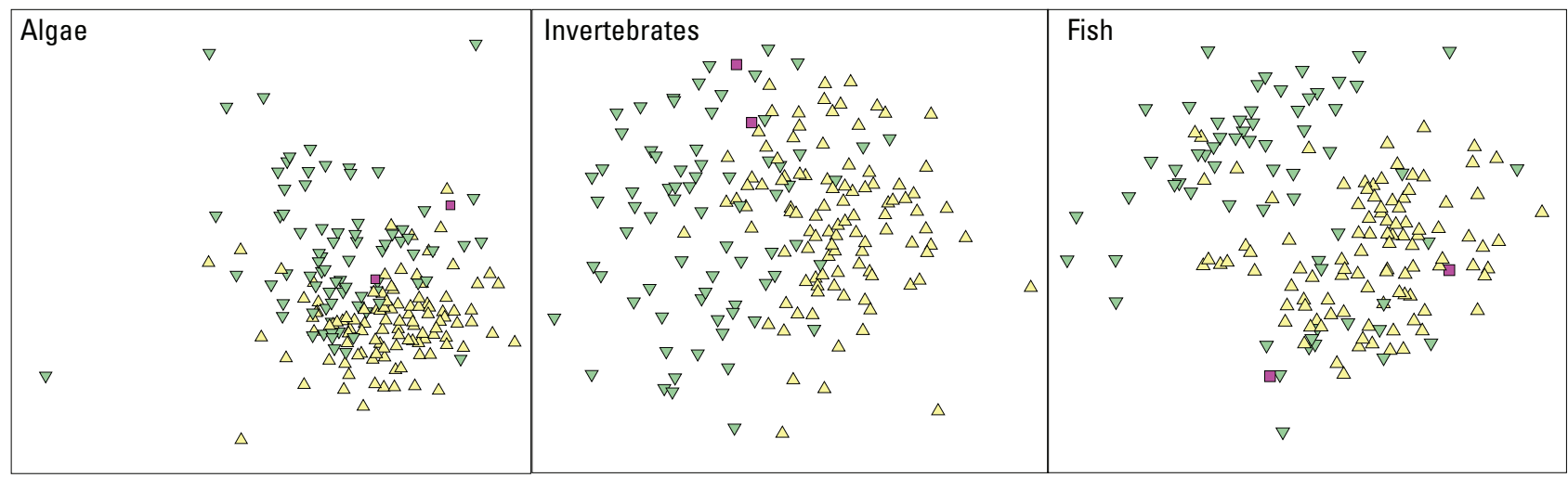

\section{EXPLANATION}

Diatom ecoregion

$\nabla$ Glaciated North

$\triangle$ Central and Western Plains

๑ Eastern Highlands

Figure 3. Ordination plots of the algae-, invertebrate-, and fish-community data.

Table 3. Spearman rank correlation coefficients from the analysis of similarity between the three diatom ecoregions.

[Bold indicates significant difference between the diatom ecoregions $(p$ value $=0.05)]$

\begin{tabular}{lccc}
\hline & \multicolumn{3}{c}{ Diatom ecoregion } \\
\cline { 2 - 4 } Community & $\begin{array}{c}\text { Glaciated North } \\
\text { to Central and } \\
\text { Western Plains }\end{array}$ & $\begin{array}{c}\text { Glaciated North } \\
\text { to Eastern } \\
\text { Highlands }\end{array}$ & $\begin{array}{c}\text { Central and } \\
\text { Western Plains } \\
\text { to Eastern } \\
\text { Highlands }\end{array}$ \\
\hline Algae & $\mathbf{0 . 2 3 1}$ & 0.123 & 0.273 \\
Invertebrates & $\mathbf{. 3 2 4}$ & .124 & $\mathbf{. 4 6 7}$ \\
Fish & $\mathbf{. 3 9 9}$ & $\mathbf{. 4 8 1}$ & .269 \\
\hline
\end{tabular}




\section{Regional Comparisons of the Nutrient Categories}

The sampling strategies and the number of samples collected for nutrients that are used to assess the nutrient condition within streams vary by State and study, depending upon the objectives of the study and available funding. In many previous studies relating stressors such as nutrients to a biological response, the nutrient data used have been a measure of nutrient concentrations nearest the biological sample (U.S. Environmental Protection Agency, 2006b; Caskey and Frey, 2009) or some measure of nutrient loading affecting the biota throughout the year; for example, the annual average or annual maximum concentrations (Indiana Department of Environmental Management, 1999). Typically, within the GNE and CWPE ecoregions, most biological community data are collected during stable low flow conditions between July and October, when nutrients are at the lowest concentrations for the year.

A nonparametric multivariate correlation analysis was done to compare which measure of nutrient condition (nutrient concentration or nutrient ratio) had the strongest relations with algal-, invertebrate-, and fish-community structure for each ecoregion separately and both ecoregions combined. For this analysis, the nutrient measures were the (1) nutrient concentration or nutrient ratio on the day of the biological sampling or as close to the day of the sampling as possible, (2) the annual average, or (3) the annual maximum concentration. For all biological communities and all nutrient categories (nearest biological sample, annual mean, and annual maximum concentrations), the ratio of nitrate to total nitrogen $\left(\mathrm{NO}_{3}: \mathrm{TN}\right)$ had the strongest single relation with all the biological communities; however, TN and TP had the most significant relations with the different biological attributes. The nutrient sample collected nearest the biological sample had the weakest relation with algae, invertebrate, and fish communities for the GNE, CWPE, and all samples combined (table 4). For all samples combined, the nutrient sample with the strongest correlation to the biotic community assemblage was the annual maximum concentration. However, for the two ecoregions, the nutrient sample with the highest correlation to the biotic community assemblage was usually the annual average concentration. On the basis of these results and the use of TN and TP in proposed nutrient criteria, the breakpoint analyses used the annual average for TN and TP.

Using the criterion for sites to have at least 6 nutrient samples and algal-, invertebrate-, and fish-community data collected within the same year, we identified 23 and 31 sites in the GNE and CWPE, respectively. The number of sites within each nutrient category ranged from 4 (TN and TP, low category) to 18 (TN, medium category) in the CWPE and from 3 (TN and TP, low category) to 15 (TN, medium category) in the GNE (table 5). The TN concentrations ranged from 0.74 to $16.1 \mathrm{mg} / \mathrm{L}$ with a median of $5.48 \mathrm{mg} / \mathrm{L}$ in the CWPE and from 0.05 to $5.52 \mathrm{mg} / \mathrm{L}$ with a median of $1.45 \mathrm{mg} / \mathrm{L}$ in the GNE. The TP concentrations ranged from 0.02 to $2.10 \mathrm{mg} / \mathrm{L}$ with a median of $0.11 \mathrm{mg} / \mathrm{L}$ in the CWPE and from 0.01 to 0.47 $\mathrm{mg} / \mathrm{L}$ with a median of $0.08 \mathrm{mg} / \mathrm{L}$ in the GNE (table 6). The main difference between the two diatom ecoregions was that $\mathrm{TN}$ and TP concentrations were about 3-5 times higher in the more agricultural and nutrient-rich CWPE than in the GNE (figs. 4 and 5).

Table 4. Summary of Spearman rho correlations for the nutrients total nitrogen and total phosphorus and the algae, invertebrate, and fish community.

[NS, not significant; bold, strongest correlation of the three nutrient variables]

\begin{tabular}{|c|c|c|c|c|c|c|c|c|c|}
\hline \multirow[b]{2}{*}{ Nutrient } & \multicolumn{3}{|c|}{ Algae } & \multicolumn{3}{|c|}{ Invertebrates } & \multicolumn{3}{|c|}{ Fish } \\
\hline & $\begin{array}{c}\text { All } \\
\text { samples }\end{array}$ & $\begin{array}{l}\text { Glaciated } \\
\text { North } \\
\text { diatom } \\
\text { ecoregion }\end{array}$ & $\begin{array}{l}\text { Central and } \\
\text { Western } \\
\text { Plains } \\
\text { diatom } \\
\text { ecoregion }\end{array}$ & $\begin{array}{c}\text { All } \\
\text { samples }\end{array}$ & $\begin{array}{l}\text { Glaciated } \\
\text { North } \\
\text { diatom } \\
\text { ecoregion }\end{array}$ & $\begin{array}{l}\text { Central and } \\
\text { Western } \\
\text { Plains } \\
\text { diatom } \\
\text { ecoregion }\end{array}$ & $\begin{array}{c}\text { All } \\
\text { samples }\end{array}$ & $\begin{array}{l}\text { Glaciated } \\
\text { North } \\
\text { diatom } \\
\text { ecoregion }\end{array}$ & $\begin{array}{c}\text { Central and } \\
\text { Western } \\
\text { Plains } \\
\text { diatom } \\
\text { ecoregion }\end{array}$ \\
\hline Bio-nutrient ${ }^{1}$ & 0.248 & 0.261 & 0.243 & 0.152 & 0.168 & 0.196 & 0.16 & 0.323 & NS \\
\hline $\begin{array}{l}\text { Annual } \\
\text { maximum }^{3}\end{array}$ & .337 & .259 & .306 & .289 & NS & .214 & .355 & .395 & .323 \\
\hline
\end{tabular}

\footnotetext{
${ }^{1}$ Nutrient concentration closest to the biological sample.

${ }^{2}$ Average nutrient concentration for the year.

${ }^{3}$ Maximum nutrient concentration for the year.
} 
Table 5. Level III ecoregion, diatom ecoregion, and nutrient categories of the 54 sampling sites in the Central and Western Plains and Glacial North diatom ecoregions.

[TN, total nitrogen; TP, total phosphorus; CWPE, Central and Western Plains diatom ecoregion; GNE, Glacial North diatom ecoregion; Med, medium; Bold shows sites that changed category when biological response was used to assign low, medium, and high categories]

\begin{tabular}{|c|c|c|c|c|c|c|c|}
\hline \multirow{2}{*}{$\begin{array}{c}\text { Site } \\
\text { number }\end{array}$} & \multirow{2}{*}{$\begin{array}{c}\text { Site } \\
\text { identification }\end{array}$} & \multirow[t]{2}{*}{ Site name } & \multirow{2}{*}{$\begin{array}{c}\text { Diatom } \\
\text { ecoregion }\end{array}$} & \multicolumn{2}{|c|}{$\begin{array}{l}\text { Nutrient } \\
\text { category }\end{array}$} & \multicolumn{2}{|c|}{$\begin{array}{c}\text { Biological } \\
\text { category }\end{array}$} \\
\hline & & & & TN & TP & TN & TP \\
\hline 1 & 04186500 & AUGLAIZE RIVER NEAR FORT JENNINGS, OH & CWPE & Med & High & High & High \\
\hline 2 & 03357330 & BIG WALNUT CREEK NEAR ROACHDALE, IN & CWPE & Med & Low & High & Low \\
\hline 3 & 040853145 & BLACK CREEK AT CURRAN ROAD NEAR DENMARK, WI & GNE & Med & High & High & High \\
\hline 4 & 04159492 & BLACK RIVER NEAR JEDDO, MI & CWPE & Med & Med & High & Med \\
\hline 5 & 04213500 & CATTARAUGUS CR AT GOWANDA, NY & GNE & Med & Low & High & Low \\
\hline 6 & 05286290 & CEDAR CREEK NEAR COOPERS CORNER, MN & GNE & Med & Med & High & Med \\
\hline 7 & 04161820 & CLINTON RIVER AT STERLING HEIGHTS, MI & GNE & Med & Med & High & Med \\
\hline 8 & 04208504 & CUYAHOGA RIVER NEAR NEWBURGH HEIGHTS, OH & GNE & High & High & High & High \\
\hline 9 & 05532500 & DES PLAINES RIVER AT RIVERSIDE, IL & CWPE & Med & High & High & High \\
\hline 10 & 05527800 & DES PLAINES RIVER AT RUSSELL, IL & CWPE & Med & Med & Med & High \\
\hline 11 & 04072050 & DUCK CREEK AT SEMINARY ROAD NEAR ONEIDA, WI & GNE & High & High & High & High \\
\hline 12 & 03246400 & EAST FORK LITTLE MIAMI RIVER NEAR WILLIAMSBURG, OH & CWPE & Low & Med & Low & High \\
\hline 13 & 04085109 & EAST RIVER AT MIDWAY ROAD NEAR DE PERE, WI & GNE & Med & High & High & High \\
\hline 14 & 05461390 & FLOOD CREEK NEAR POWERSVILLE, IA & CWPE & High & Med & High & Med \\
\hline 15 & 04211820 & GRAND RIVER AT HARPERSFIELD, OH & GNE & Med & Med & Med & Med \\
\hline 16 & 393944084120700 & HOLES CK IN HUFFMAN PARK AT KETTERING, OH & CWPE & Low & Low & Low & Low \\
\hline 17 & 05568800 & INDIAN CREEK NEAR WYOMING, IL & CWPE & High & Med & High & Med \\
\hline 18 & 05449500 & IOWA RIVER NEAR ROWAN, IA & CWPE & Med & High & High & High \\
\hline 19 & 03360895 & KESSINGER DITCH NEAR MONROE CITY, IN & CWPE & Med & Med & High & Med \\
\hline 20 & 05584500 & LA MOINE RIVER AT COLMAR, IL & CWPE & Med & High & High & High \\
\hline 21 & 05320270 & LITTLE COBB RIVER NEAR BEAUFORD, MN & CWPE & High & High & High & High \\
\hline 22 & 03373530 & LOST RIVER NEAR LEIPSIC, IN & CWPE & Med & Med & High & Low \\
\hline 23 & 03267900 & MAD RIVER AT ST PARIS PIKE AT EAGLE CITY, OH & CWPE & Med & Med & High & Low \\
\hline 24 & 04087000 & MILWAUKEE RIVER AT MILWAUKEE, WI & GNE & Med & Med & High & High \\
\hline 25 & 03366500 & MUSCATATUCK RIVER NEAR DEPUTY, IN & CWPE & Low & Med & Low & Med \\
\hline 26 & 05331833 & NAMEKAGON RIVER AT LEONARDS, WI & GNE & Low & Low & Low & Low \\
\hline 27 & 05330902 & NINE MILE CREEK NEAR JAMES CIRCLE AT BLOOMINGTON, MN & GNE & Med & Med & High & Med \\
\hline 28 & 05548105 & NIPPERSINK CREEK ABOVE WONDER LAKE, IL & CWPE & Med & Med & High & Med \\
\hline 29 & 040863075 & NORTH BRANCH MILWAUKEE RIVER NEAR RANDOM LAKE, WI & GNE & High & High & High & High \\
\hline
\end{tabular}


Table 5. Level III ecoregion, diatom ecoregion, and nutrient categories of the 54 sampling sites in the Central and Western Plains and Glacial North diatom ecoregions.-Continued

[TN, total nitrogen; TP, total phosphorus; CWPE, Central and Western Plains diatom ecoregion; GNE, Glacial North diatom ecoregion; Med, medium; Bold shows sites that changed category when biological response was used to assign low, medium, and high categories]

\begin{tabular}{|c|c|c|c|c|c|c|c|}
\hline \multirow{2}{*}{$\begin{array}{c}\text { Site } \\
\text { number }\end{array}$} & \multirow{2}{*}{$\begin{array}{c}\text { Site } \\
\text { identification }\end{array}$} & \multirow[t]{2}{*}{ Site name } & \multirow{2}{*}{$\begin{array}{c}\text { Diatom } \\
\text { ecoregion }\end{array}$} & \multicolumn{2}{|c|}{$\begin{array}{l}\text { Nutrient } \\
\text { category }\end{array}$} & \multicolumn{2}{|c|}{$\begin{array}{c}\text { Biological } \\
\text { category }\end{array}$} \\
\hline & & & & TN & TP & TN & TP \\
\hline 30 & 05276005 & NORTH FORK CROW RIVER ABOVE PAYNESVILLE, MN & GNE & Med & Med & High & Med \\
\hline 31 & 04087204 & OAK CREEK AT SOUTH MILWAUKEE, WI & GNE & Med & Med & Med & Med \\
\hline 32 & 05455100 & OLD MANS CREEK NEAR IOWA CITY, IA & CWPE & High & High & High & High \\
\hline 33 & 05030150 & OTTER TAIL RIVER NEAR PERHAM, MN & GNE & Med & Med & Med & Med \\
\hline 34 & 05567000 & PANTHER CREEK NEAR EL PASO, IL & CWPE & High & Med & High & High \\
\hline 35 & 04071795 & PENSAUKEE RIVER NEAR KRAKOW, WI & GNE & Med & High & High & High \\
\hline 36 & 04062085 & PESHEKEE RIVER NEAR MARTINS LANDING, MI & GNE & Low & Low & Low & Low \\
\hline 37 & 04087258 & PIKE RIVER AT CTH A NEAR KENOSHA, WI & CWPE & Med & Med & High & Med \\
\hline 38 & 04063700 & POPPLE RIVER NEAR FENCE, WI & GNE & Low & Med & Low & Low \\
\hline 39 & 04085188 & RIO CREEK AT PHEASANT ROAD NEAR RIO CREEK, WI & GNE & High & High & High & High \\
\hline 40 & 04175600 & RIVER RAISIN NEAR MANCHESTER, MI & GNE & Med & Med & Med & Low \\
\hline 41 & 05531500 & SALT CREEK AT WESTERN SPRINGS, IL & CWPE & Med & High & High & High \\
\hline 42 & 05572000 & SANGAMON RIVER AT MONTICELLO, IL & CWPE & High & Med & High & High \\
\hline 43 & 05288705 & SHINGLE CREEK AT QUEEN AVE IN MINNEAPOLIS, MN & GNE & Med & Med & High & Med \\
\hline 44 & 05451210 & SOUTH FORK IOWA RIVER NE OF NEW PROVIDENCE, IA & CWPE & High & Med & High & Med \\
\hline 45 & 04178000 & ST JOSEPH RIVER NEAR NEWVILLE, IN & CWPE & Med & Med & Med & Med \\
\hline 46 & 395355084173600 & STILLWATER R. ON MARTINDALE R. NEAR UNION, OH & CWPE & Med & Med & High & High \\
\hline 47 & 394340085524601 & SUGAR CREEK AT CO RD 400 S AT NEW PALESTINE, IN & CWPE & Med & Med & Med & Low \\
\hline 48 & 05525500 & SUGAR CREEK AT MILFORD, IL & CWPE & High & Med & High & Med \\
\hline 49 & 04080798 & TOMORROW RIVER NEAR NELSONVILLE, WI & GNE & High & Med & High & Low \\
\hline 50 & 05082625 & TURTLE R AT TURTLE R STATE PARK NEAR ARVILLA, ND & GNE & Med & Med & High & Med \\
\hline 51 & 05420680 & WAPSIPINICON RIVER NEAR TRIPOLI, IA & CWPE & Med & Med & High & Med \\
\hline 52 & 03275000 & WHITEWATER RIVER NEAR ALPINE, IN & CWPE & Med & Low & High & Low \\
\hline 53 & 05062500 & WILD RICE RIVER AT TWIN VALLEY, MN & CWPE & Low & Low & Low & Low \\
\hline 54 & 05464220 & WOLF CREEK NEAR DYSART, IA & CWPE & High & Med & High & High \\
\hline
\end{tabular}




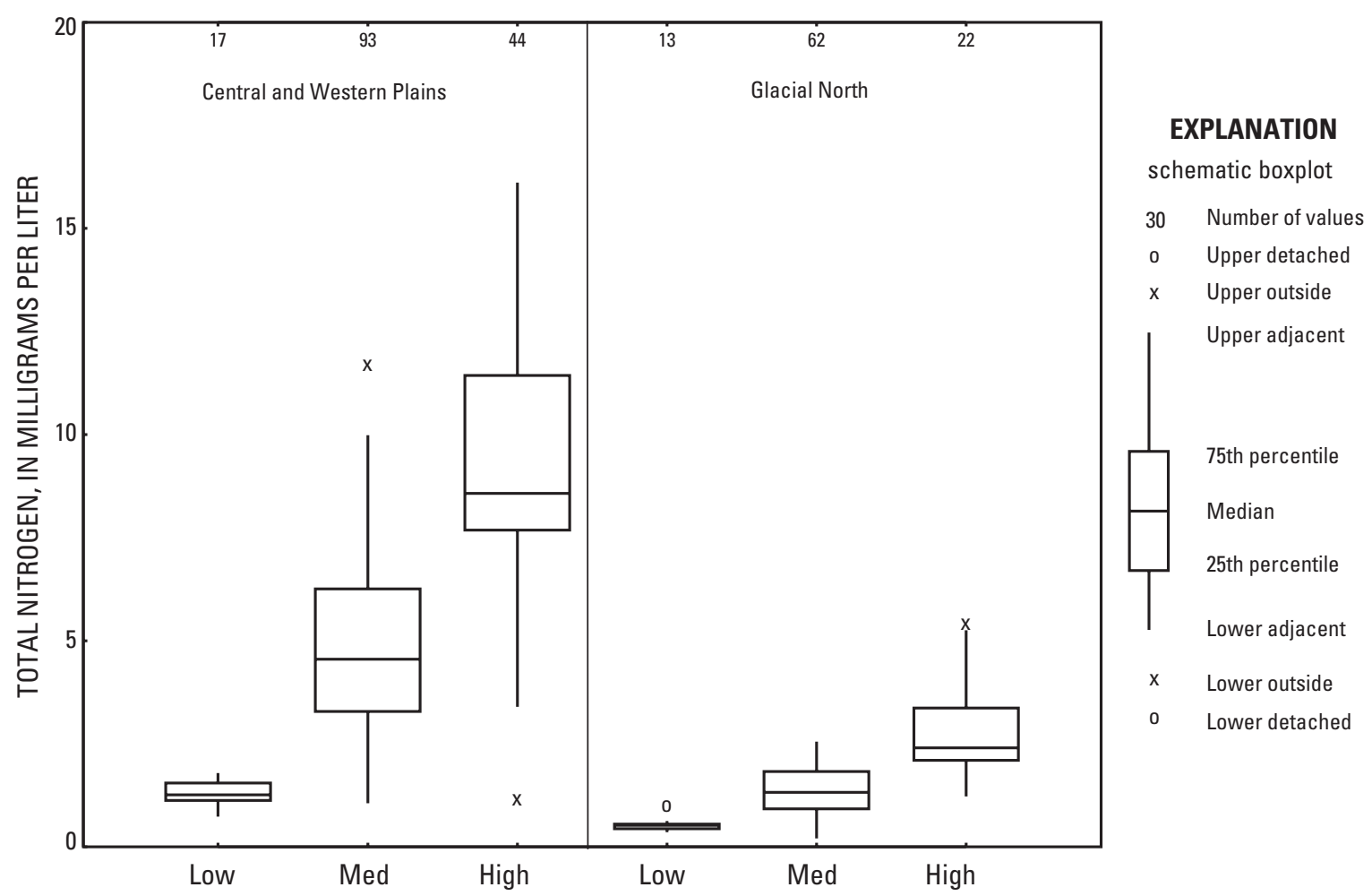

Figure 4. Distribution of median annual total nitrogen concentrations in the low-, medium-, and high-nutrient categories in the Central and Western Plains and Glacial North diatom ecoregions.

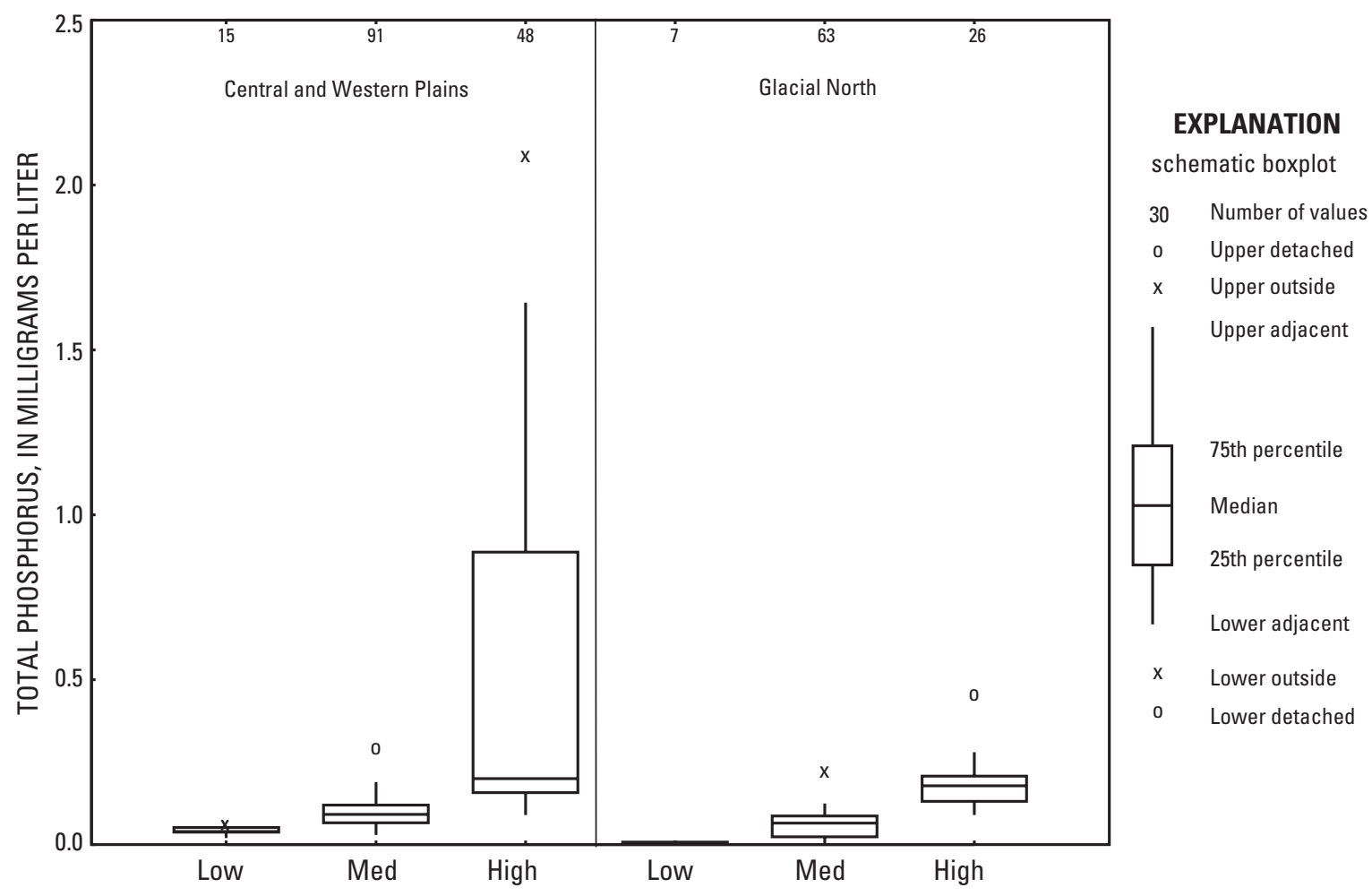

Figure 5. Distribution of median annual total phosphorus concentrations in the low-, medium-, and high-nutrient categories in the Central and Western Plains and Glacial North diatom ecoregions. 
Table 6. Summary statistics for total nitrogen and total phosphorus in the Central and Western Plains and Glacial North diatom ecoregions.

$[\mathrm{mg} / \mathrm{L}$, milligrams per liter; concentrations in bold slightly differ from the values used to classify nutrient categories]

\begin{tabular}{lcc}
\hline \multicolumn{1}{c}{ Statistic } & $\begin{array}{c}\text { Total nitrogen } \\
\text { (mg/L) }\end{array}$ & $\begin{array}{c}\text { Total phosphorus } \\
\text { (mg/L) }\end{array}$ \\
\hline \multicolumn{1}{c}{ Central and Western Plains diatom ecoregion } \\
\hline Minimum & 0.74 & 0.02 \\
10th percentile & $\mathbf{1 . 5 5}$ & .05 \\
25th percentile & 2.99 & .07 \\
Median & 5.48 & .11 \\
75th percentile & 7.77 &. $\mathbf{1 6}$ \\
90th percentile & 10.8 & .71 \\
Maximum & 16.1 & 2.10 \\
\hline & Glacial North diatom ecoregion & \\
Minimum & 0.05 & 0.01 \\
10th percentile & $\mathbf{. 5 2}$ & .02 \\
25th percentile & .87 & .03 \\
Median & 1.45 & .08 \\
75th percentile & $\mathbf{2 . 0 0}$ & .13 \\
90th percentile & 2.58 & .20 \\
Maximum & 5.52 & .47 \\
& &
\end{tabular}

\section{Comparison of Seasonal Nutrient Concentrations by Nutrient Categories}

Seasonally, the highest TN concentrations within the CWPE and GNE were found in the spring, after the application of fertilizer to fields; concentrations decreased steadily from June through October because of (1) nutrient uptake from crops and terrestrial plants, (2) nutrient uptake by algae and macrophytes in streams, and (3) decreased nutrient runoff to streams from drier soils, which are better able to absorb precipitation (fig. 6). Concentrations of TN increased in the fall and winter because of decreased plant uptake and application of manure and fertilizer. In general, the seasonal patterns of high and low concentrations in the low-, medium-, and highnutrient categories were similar for TN; however, the main difference between the sites in these categories was the magnitude of nutrient concentrations. For example, one can compare the TN concentrations in three similarly sized agricultural sites in the CWPE, all within USEPA Nutrient Ecoregion VI, where the proposed criterion is $2.18 \mathrm{mg} / \mathrm{L}$. At the low-TN site, Muscatatuck River in Indiana (site 25), TN ranged from 1.02 to $3.30 \mathrm{mg} / \mathrm{L}$, and concentrations in 75 percent of the samples were below the USEPA proposed criterion (fig. 7).

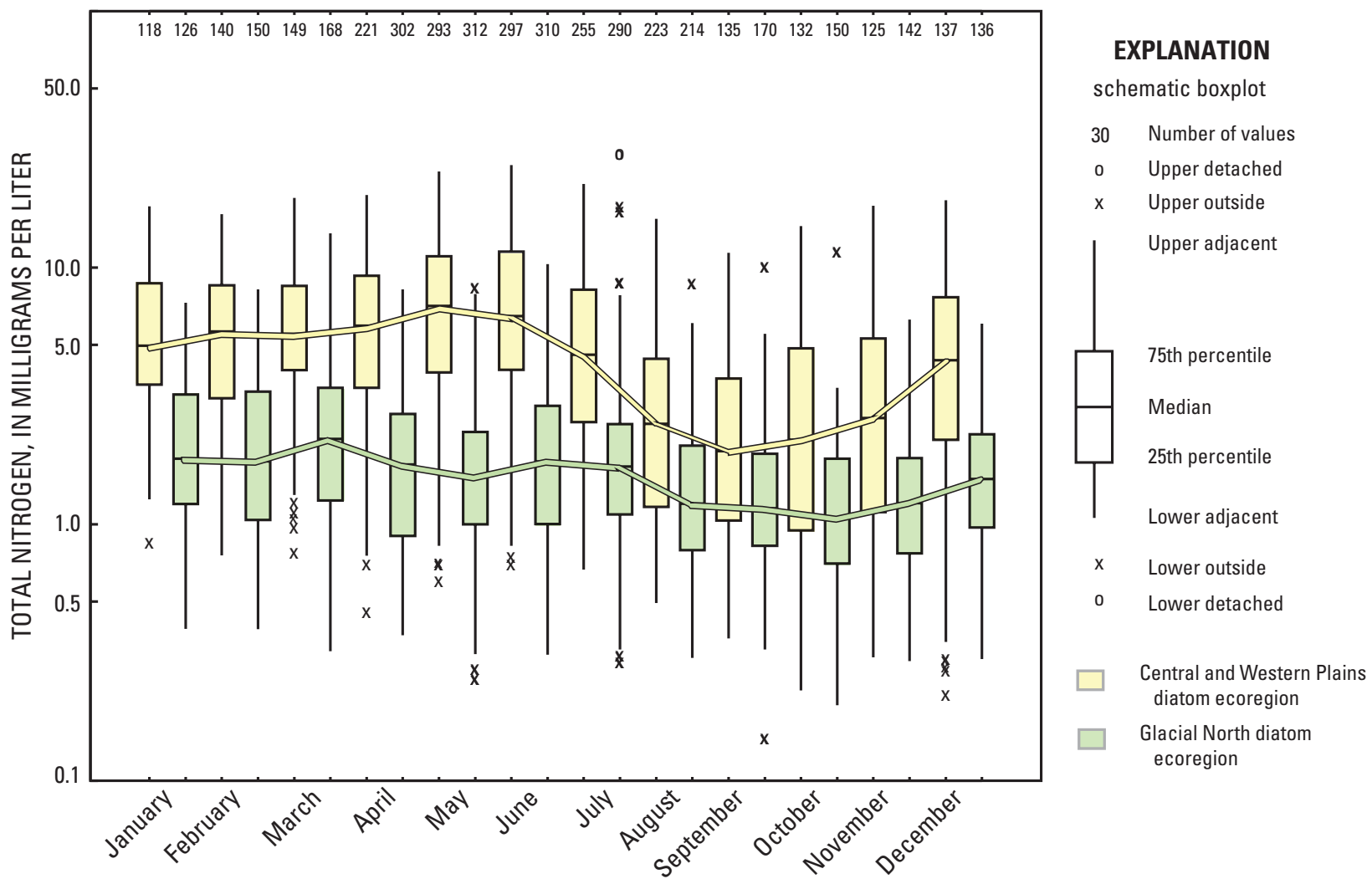

Figure 6. Monthly concentrations of total nitrogen at the 64 sites within Central and Western Plains and Glacial North diatom ecoregions used to determine nutrient categories. 


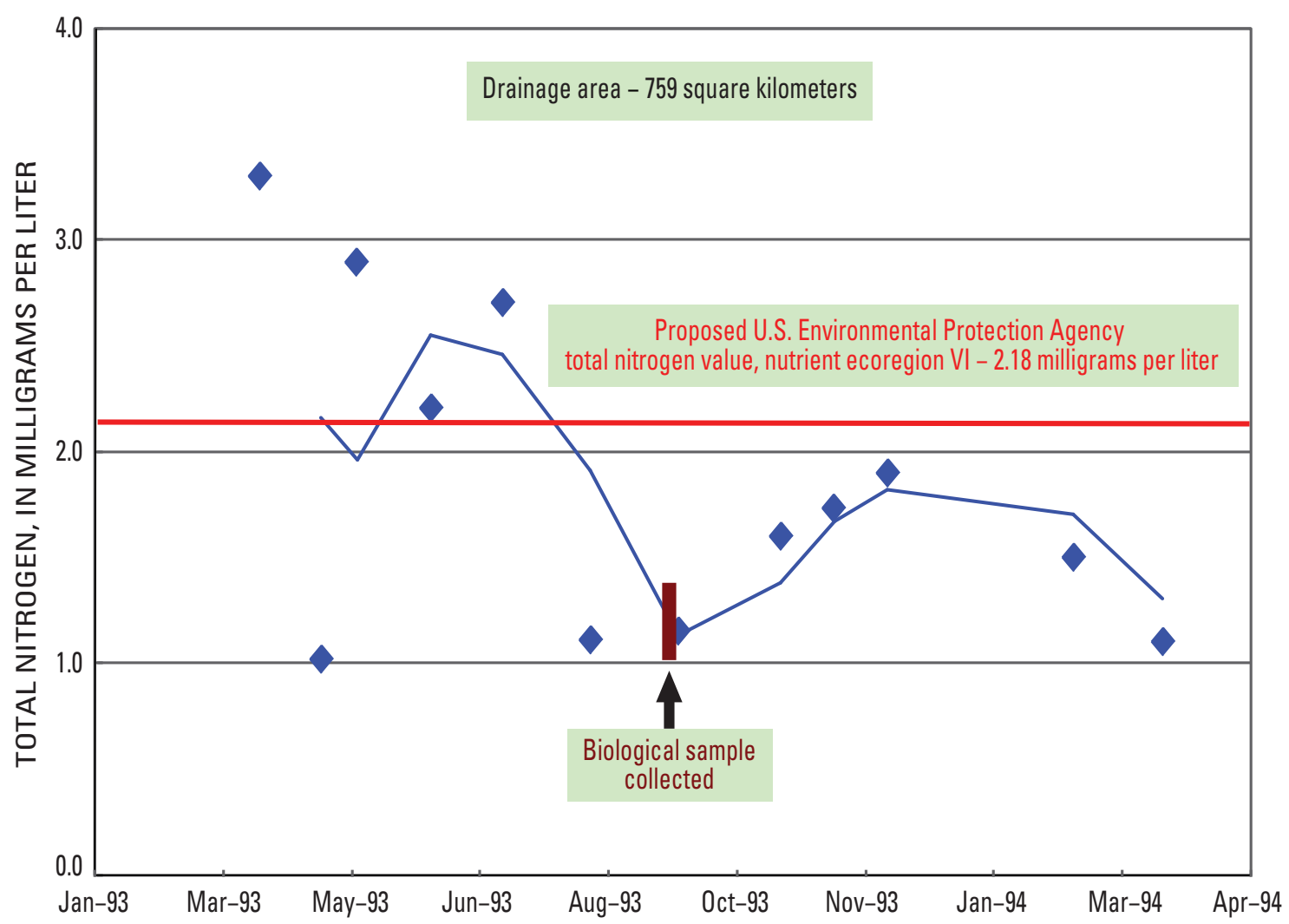

Figure 7. Seasonal concentrations of total nitrogen (TN) at the low-TN site Muscatatuck River, Indiana. (The blue line on the graph indicates a Lowess smooth.)

At the medium-TN site, Sugar Creek in Indiana (site 47), TN ranged from 0.57 to $7.70 \mathrm{mg} / \mathrm{L}$, and concentrations in about 63 percent of the samples were below the USEPA proposed criterion for TN (fig. 8). At the high-TN site, Little Cobb River in Minnesota (site 21), TN ranged from 3.03 to $14.4 \mathrm{mg} / \mathrm{L}$, and concentrations in 100 percent of the samples were above the USEPA proposed criterion for TN (fig. 9). Similar trends for TN were found in the low, medium, and high categories within the CWPE and GNE ecoregions.

Seasonally, the highest TP concentrations in streams within the CWPE and GNE ecoregions were found in June and July, after application of fertilizer and manure (fig. 10). Unlike the pattern of concentrations of TN, however, concentrations of TP in streams were low in the winter and increased to the highest concentrations during May and June and then steadily decreased through the fall and winter. Variability was greater for seasonal concentrations of TP than for TN. Likewise, the differences in the magnitude and seasonal trends of nutrient concentrations between the low, medium, and high categories for TP was less consistent than the patterns found for TN.

\section{Biological Conditions Within the Nutrient Categories}

The next step was to determine whether the designated nutrient categories within the ecoregions were significantly different on the basis of species composition of the samples. Comparable to the analysis to determine differences in nutrients between the ecoregions, a similarity analysis based on the community composition was used to distinguish significant differences in the biological communities among the nutrient categories (table 7). All biological communities were significantly different between at least one nutrient category for TN and TP in each ecoregion but were not consistently different from one ecoregion to the other. In the GNE, the algal community was most dissimilar between the low and high and low and medium sites for both TN and TP. In the more nutrientrich CWPE, however, fish were more different between the low and high and low and medium sites for both TN and TP. 


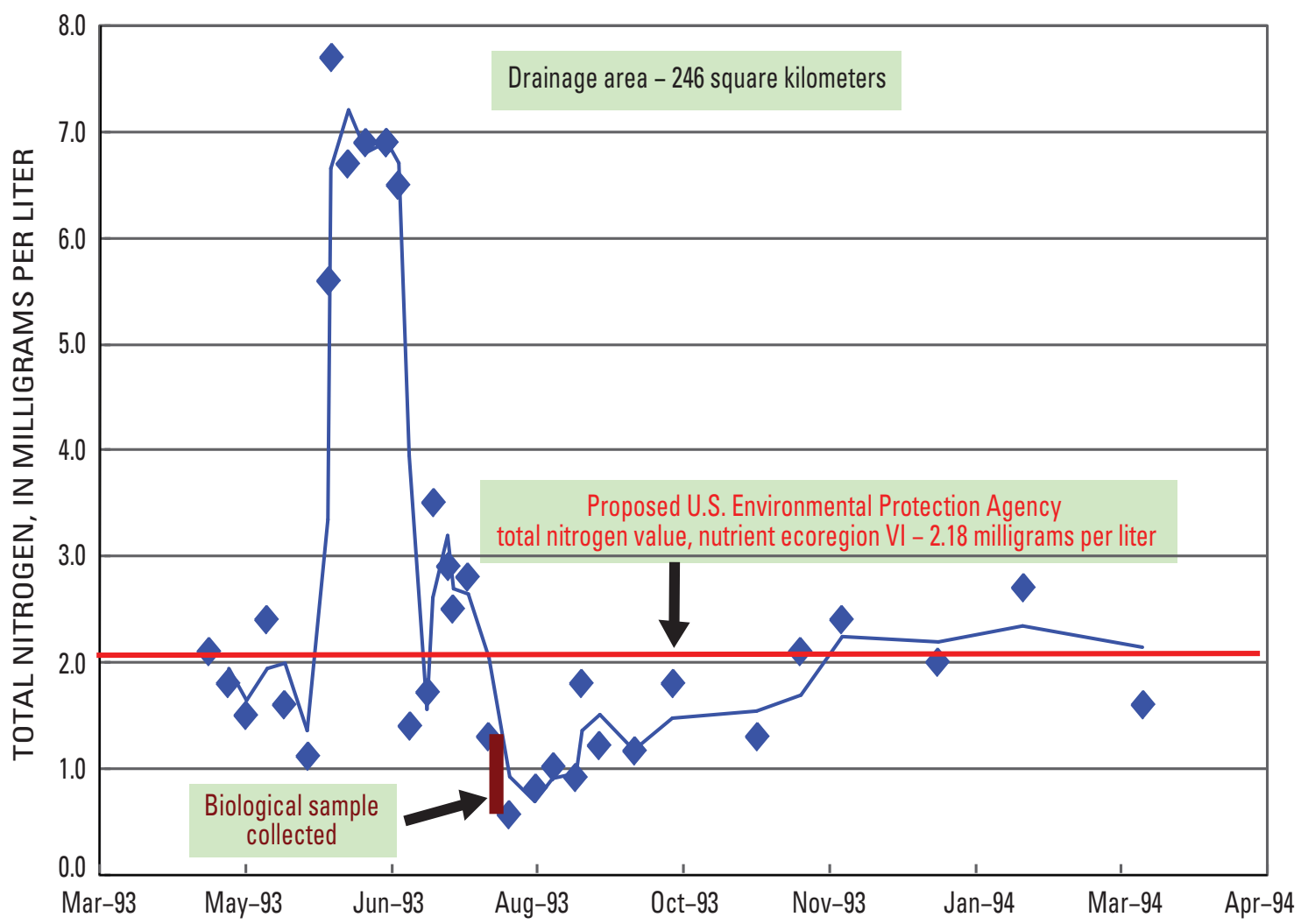

Figure 8. Seasonal concentrations of total nitrogen (TN) at the medium-TN site Sugar Creek, Indiana. (The blue line on the graph indicates a Lowess smooth.)

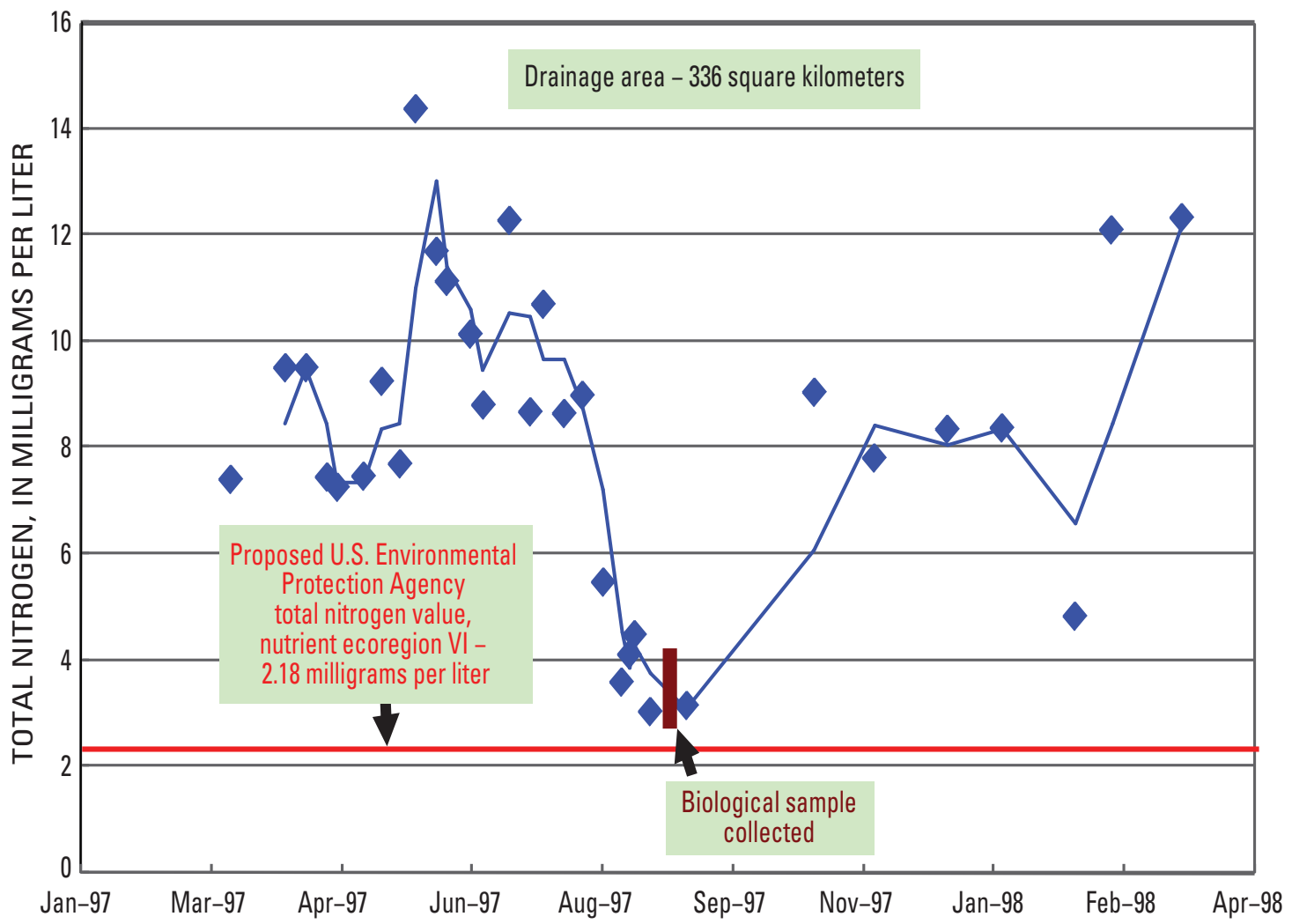

Figure 9. Seasonal concentrations of total nitrogen (TN) at the high-TN site Little Cobb River, Minnesota. (The blue line on the graph indicates a Lowess smooth.) 


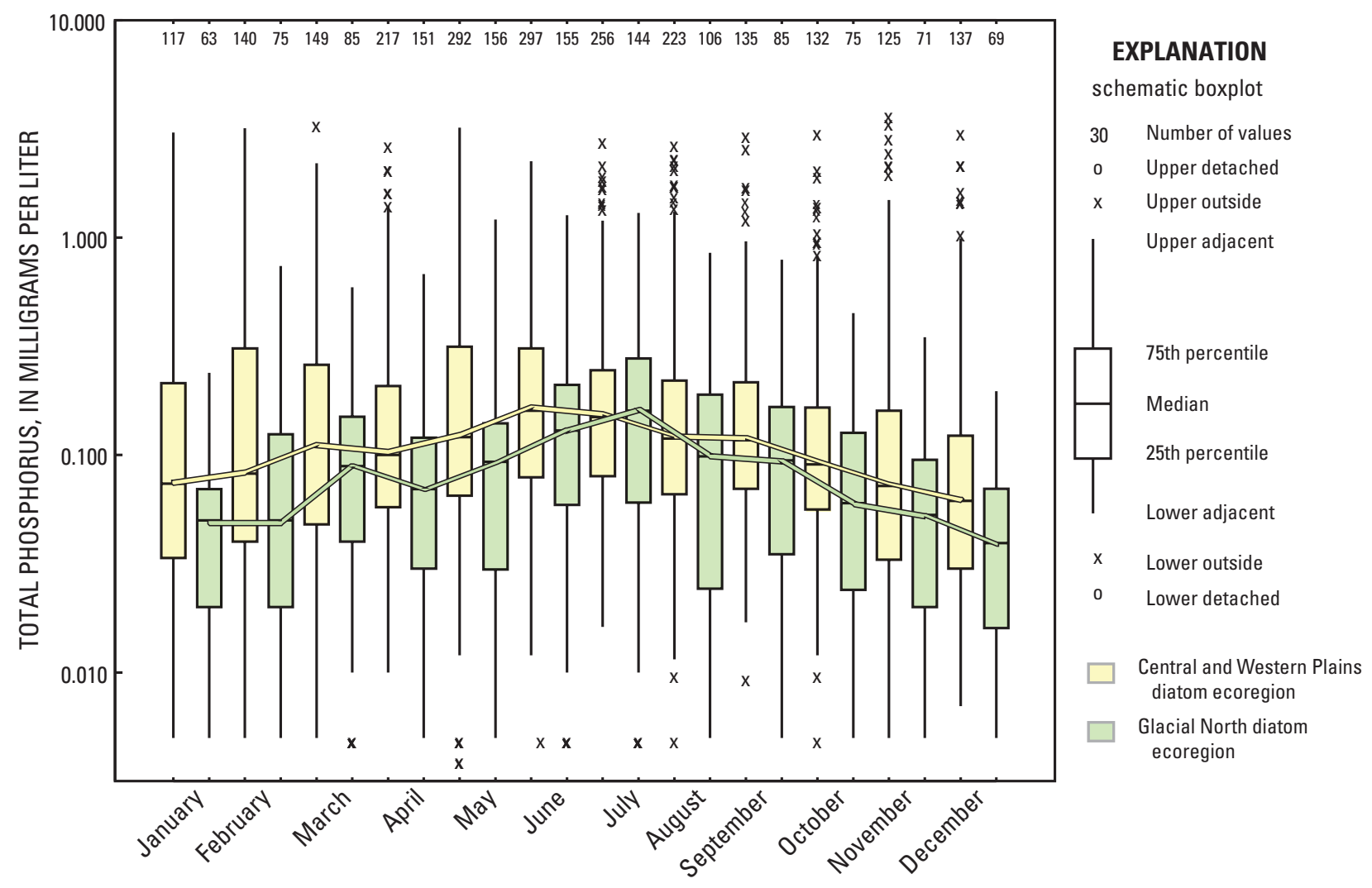

Figure 10. Monthly concentrations of total phosphorus at the 64 sites within Central and Western Plains and Glacial North diatom ecoregions used to determine nutrient categories.

Table 7. Spearman rank correlation coefficients from the analysis of similarity between the three nutrient categories.

[Bold indicates significant difference between the nutrient categories $(p$ value $=0.05)$ ]

\begin{tabular}{|c|c|c|c|c|c|c|}
\hline \multirow{3}{*}{ Community } & \multicolumn{6}{|c|}{ Diatom ecoregion } \\
\hline & \multicolumn{3}{|c|}{ Central and Western Plains } & \multicolumn{3}{|c|}{ Glaciated North } \\
\hline & $\begin{array}{l}\text { Low to } \\
\text { medium }\end{array}$ & Low to high & $\begin{array}{l}\text { Medium to } \\
\text { high }\end{array}$ & $\begin{array}{l}\text { Low to } \\
\text { medium }\end{array}$ & Low to high & $\begin{array}{c}\text { Medium to } \\
\text { high }\end{array}$ \\
\hline \multicolumn{7}{|c|}{ Annual average total nitrogen } \\
\hline Algae & 0.257 & 0.485 & 0.070 & 0.493 & 0.665 & -0.025 \\
\hline Invertebrates & .003 & .529 & .071 & .262 & .411 & .160 \\
\hline Fish & 297 & .562 & .115 & .301 & .099 & .079 \\
\hline \multicolumn{7}{|c|}{ Annual average total phosphorus } \\
\hline Algae & 0.180 & 0.347 & 0.160 & 0.408 & 0.721 & 0.095 \\
\hline Invertebrates & .055 & .234 & -.004 & .182 & .552 & .154 \\
\hline Fish & .079 & .652 & .037 & .308 & .602 & -.028 \\
\hline
\end{tabular}


Certain species of algae, invertebrates, and fish were more prevalent in and characteristic of either the low- or the high-nutrient condition within each of the ecoregions. For the most part, the species in the medium-nutrient categories consisted of a mix of species in the low or high categories and reflected a transition from the low to high nutrient levels. Some species were found in similar relative abundance regardless of nutrient category. In particular, the species that increase or decrease in abundance with corresponding changes in nutrient concentrations could be useful indicators of nutrient conditions within streams and may be useful for development of nutrient biotic indices for states within these regions. For this analysis, a given algae, invertebrate, or fish taxa was considered indicative of low nutrient (TN or TP) concentrations if the relative abundance consistently decreased in value from low- to medium- to high-nutrient categories or was found only in the low-nutrient category. To be considered an indicator of high nutrient concentrations, the taxa had to consistently decrease in value from high to medium to low categories or be found only in the high-nutrient category. Taxa that occur in all nutrient categories without a consistent upward or downward trend or those only occurring in the medium category are considered common and ubiquitous.

\section{Algae}

To describe nutrient conditions in streams on the basis of algal-community data, identification to genus of algae is not specific enough to distinguish low- and high-nutrient taxa (Hill and others, 2000). For example, the freshwater diatom Nitzschia, a genus with more than 600 species (Wehr and Sheath, 2003), includes species that are abundant in low- or high-nutrient conditions, as well as species that are ubiquitous in all nutrient conditions. Many Nitzschia species are recognized as indicators of organic enrichment (Lowe, 1974) and are pollution tolerant. Cholnoky (1938) suggested that Nitzschia are nutrient tolerant because many species are nitrogen heterotrophs and use organic nitrogen in the water column. One strength of incorporating the algal community structure into nutrient stressor studies is that algae directly use nutrients (unlike invertebrates or fish), so the abundance, diversity, and evenness of the algal species are limited by the available nutrients (Pringle, 1990; Biggs and Smith, 2002). When nutrients are abundant they can stimulate algal blooms, whereas with lower concentrations of $\mathrm{N}$ or $\mathrm{P}$, the algal community will grow only to the level that can be supported by these nutrients.

\section{Central and Western Plains Diatom Ecoregion}

In the high-nutrient conditions in streams of the CWPE, 12 species in 3 genera dominated the algal community (table 8). The most abundant taxa indicative of high TP conditions were five Navicula species (recens, minima, subminuscula, erifuga, and trivalis), three Nitzschia species (amphibia, palea, and palea debilis), and a single Cyclotella species (meneghiniana). The most abundant taxa indicative of high TN conditions were four Navicula species (cryptotonella, subminiscula, palea, and symmetrica). Three species indicative of conditions in the low TP category (Gomphonema kobayasii, Nitzschia inconspicua, and Amphora pediculus) accounted for nearly one-third of the relative abundance, unlike the high TP category, where 10 Navicula and Nitzschia species were relatively evenly represented. Rhoicosphenia abbreviata, Reimeria sinuata f. antiqua, Achnanthidium minutissimum, and Cocconeis pediculus were indicative of conditions in the low TN category. Gomphonema minutum was ubiquitous in all nutrient categories, along with Navicula cryptotonella in all TP categories and Nitzschia inconspicua, Amphora pediculus, and Nitzschia dissipata in all TN categories.

\section{Glaciated North Diatom Ecoregion}

Several of the same algal species that indicated highnutrient conditions in the CWPE also were indicators of high-nutrient conditions in streams in the GNE. Amphora pediculus in particular dominates in the high TN and TP categories, with about 20 and 22 percent relative abundance, respectively. Three Navicula species (tripunctata, cryptotonella, and secreta) were common in streams with high TN or TP conditions, as was Navicula minima in high TP conditions. Nitzschia inconspicua was the only ubiquitous species found in all of the GNE TN nutrient categories.

In low TN and TP categories, Achnanthidium minutissimum and Achnanthidium deflexum dominated the algal community with about 25 and 30 percent of the relative abundance, respectively (table 8). Many other studies have found Achnanthidium minutissimum to be indicative of low TN and TP conditions (Van Dam and others, 1994; Fore and Grafe, 2002). Additionally, Pseudostaurosira brevistriata preferred the low category for TN and TP. Six species from the family Fragilariaceae were found exclusively in the low TN category (table 8). Although these six species prefer varying trophic conditions ranging from mesoeutrophic to eutrophic, four of the six species are in the Bahls' pollution class that are considered moderately tolerant to intolerant of nutrient and organic enrichment, and the other two are only somewhat tolerant of nutrient and organic enrichment (Bahls, 1993; Van Dam and others, 1994; Porter, 2008), which may explain the occurrence of these species at the lower TN sites. 
Table 8. Most abundant algal taxa in the total nitrogen and total phosphorus nutrient categories in the Central and Western Plains and Glacial North diatom ecoregions.

[mg/L, milligrams per liter; Mean, mean relative abundance for each taxa or species within each nutrient category]

\begin{tabular}{|c|c|c|c|c|c|}
\hline \multicolumn{6}{|c|}{ Central and Western Plains diatom ecoregion - Total phosphorus } \\
\hline \multicolumn{2}{|c|}{$\underline{\text { Low sites }(<0.05 \mathrm{mg} / \mathrm{L})}$} & \multicolumn{2}{|c|}{ Medium sites $(>0.05-<0.17 \mathrm{mg} / \mathrm{L})$} & \multicolumn{2}{|c|}{ High sites (>0.17 mg/L) } \\
\hline Taxa & Mean & Taxa & Mean & Taxa & Mean \\
\hline Gomphonema kobayasii & 11.06 & Amphora pediculus & 8.18 & Amphora pediculus & 6.30 \\
\hline Nitzschia inconspicua & 10.33 & Navicula cryptotenella & 5.88 & Navicula recens & 5.16 \\
\hline Amphora pediculus & 10.30 & Nitzschia inconspicua & 5.10 & Navicula cryptotenella & 4.22 \\
\hline Rhoicosphenia abbreviata & 7.28 & Navicula minima & 4.29 & Navicula minima & 3.90 \\
\hline Cymbella affinis & 5.39 & Rhoicosphenia abbreviata & 4.15 & Cyclotella meneghiniana & 3.83 \\
\hline Navicula cryptotenella & 4.30 & Nitzschia dissipata & 3.29 & Nitzschia inconspicua & 3.51 \\
\hline $\begin{array}{l}\text { Achnanthidium } \\
\text { minutissimum }\end{array}$ & 3.73 & $\begin{array}{l}\text { Cocconeis placentula } \\
\text { var. lineata }\end{array}$ & 2.91 & Rhoicosphenia abbreviata & 3.41 \\
\hline Nitzschia dissipata & 3.51 & Cyclotella meneghiniana & 2.41 & Nitzschia amphibia & 3.22 \\
\hline Cocconeis pediculus & 3.00 & Cymbella atomus & 2.12 & $\begin{array}{l}\text { Cocconeis placentula } \\
\text { var. lineata }\end{array}$ & 2.71 \\
\hline $\begin{array}{l}\text { Unknown Cyanophyte } \\
\text { Oscillatoriales }\end{array}$ & 3.00 & Gomphonema minutum & 2.03 & Nitzschia palea & 2.31 \\
\hline Gomphonema minutum & 2.43 & Navicula subminuscula & 1.93 & Navicula subminuscula & 2.29 \\
\hline Navicula capitatoradiata & 2.17 & $\begin{array}{l}\text { Cocconeis placentula } \\
\text { var. euglypta }\end{array}$ & 1.69 & Navicula erifuga & 2.04 \\
\hline Amphora inariensis & 2.08 & Nitzschia palea & 1.57 & Cymbella atomus & 1.92 \\
\hline Encyonema silesiacum & 1.29 & Gomphonema kobayasii & 1.55 & Navicula trivialis & 1.78 \\
\hline \multirow{7}{*}{$\begin{array}{l}\text { Unknown Cyanophyte } \\
\text { Oscillatoriales (no sheath) }\end{array}$} & 1.22 & Nitzschia amphibia & 1.53 & Nitzschia palea var. debilis & 1.65 \\
\hline & & Navicula tripunctata & 1.34 & Gomphonema kobayasii & 1.59 \\
\hline & & Navicula germainii & 1.28 & Gomphonema minutum & 1.42 \\
\hline & & Navicula reichardtiana & 1.25 & $\begin{array}{l}\text { Cocconeis placentula } \\
\text { var. euglypta }\end{array}$ & 1.39 \\
\hline & & Nitzschia frustulum & 1.16 & Gomphonema parvulum & 1.13 \\
\hline & & Simonsenia delognei & 1.15 & Sellaphora seminulum & 1.06 \\
\hline & & Navicula symmetrica & 1.10 & & \\
\hline Total top 5 species & 44.37 & & 27.59 & & 23.41 \\
\hline
\end{tabular}


Table 8. Most abundant algal taxa in the total nitrogen and total phosphorus nutrient categories in the Central and Western Plains and Glacial North diatom ecoregions.-Continued

[mg/L, milligrams per liter; Mean, mean relative abundance for each taxa or species within each nutrient category]

\begin{tabular}{|c|c|c|c|c|c|}
\hline \multicolumn{6}{|c|}{ Glacial North diatom ecoregion - Total phosphorus } \\
\hline \multicolumn{2}{|c|}{ Low sites $(<0.01 \mathrm{mg} / \mathrm{L})$} & \multicolumn{2}{|c|}{ Medium sites $(>0.01-<0.13 \mathrm{mg} / \mathrm{L})$} & \multicolumn{2}{|c|}{ High sites (>0.13 mg/L) } \\
\hline Taxa & Mean & Taxa & Mean & Taxa & Mean \\
\hline $\begin{array}{l}\text { Achnanthidium } \\
\text { minutissimum }\end{array}$ & 28.34 & Amphora pediculus & 6.57 & Amphora pediculus & 22.10 \\
\hline Oscillatoria limnetica & 4.56 & $\begin{array}{l}\text { Achnanthidium } \\
\text { minutissimum }\end{array}$ & 5.85 & Navicula tripunctata & 8.78 \\
\hline Cocconeis placentula & 2.34 & Nitzschia inconspicua & 5.80 & Navicula minima & 6.55 \\
\hline Cymbella delicatula & 2.30 & Navicula cryptotenella & 3.68 & Navicula cryptotenella & 6.44 \\
\hline Achnanthidium deflexum & 2.17 & Rhoicosphenia abbreviata & 3.53 & Rhoicosphenia abbreviata & 5.60 \\
\hline Navicula cryptotenella & 2.02 & Navicula tripunctata & 2.47 & $\begin{array}{c}\text { Navicula secreta } \\
\text { var. apiculata }\end{array}$ & 3.23 \\
\hline $\begin{array}{l}\text { Pseudostaurosira } \\
\text { brevistriata }\end{array}$ & 2.00 & Cyclotella meneghiniana & 2.00 & Nitzschia inconspicua & 3.19 \\
\hline Staurosirella pinnata & 1.34 & Nitzschia dissipata & 1.93 & Gomphonema olivaceum & 2.85 \\
\hline $\begin{array}{l}\text { Staurosira construens } \\
\text { var. venter }\end{array}$ & 1.14 & $\begin{array}{l}\text { Staurosira construens } \\
\text { var. venter }\end{array}$ & 1.92 & Nitzschia dissipata & 2.46 \\
\hline \multirow[t]{9}{*}{ Reimeria sinuata } & 1.13 & $\begin{array}{l}\text { Cocconeis placentula } \\
\text { var. euglypta }\end{array}$ & 1.86 & Platessa conspicua & 1.86 \\
\hline & & Navicula minima & 1.76 & Melosira varians & 1.54 \\
\hline & & Staurosirella pinnata & 1.58 & $\begin{array}{l}\text { Unknown Rhodophyte } \\
\text { Florideophycidae } \\
\text { (chantransia) }\end{array}$ & 1.51 \\
\hline & & Nitzschia amphibia & 1.43 & Planothidium rostratum & 1.41 \\
\hline & & Gomphonema parvulum & 1.40 & Homoeothrix janthina & 1.20 \\
\hline & & Cocconeis placentula & 1.33 & Gomphonema parvulum & 1.19 \\
\hline & & Fragilaria vaucheriae & 1.17 & Navicula capitatoradiata & 1.16 \\
\hline & & $\begin{array}{l}\text { Cocconeis placentula } \\
\text { var. lineata }\end{array}$ & 1.12 & & \\
\hline & & Navicula capitatoradiata & 1.00 & & \\
\hline Total top 5 species & 39.71 & & 25.44 & & 49.46 \\
\hline
\end{tabular}


Table 8. Most abundant algal taxa in the total nitrogen and total phosphorus nutrient categories in the Central and Western Plains and Glacial North diatom ecoregions.-Continued

[mg/L, milligrams per liter; Mean, mean relative abundance for each taxa or species within each nutrient category]

\begin{tabular}{|c|c|c|c|c|c|}
\hline \multicolumn{6}{|c|}{ Central and Western Plains diatom ecoregion - Total nitrogen } \\
\hline \multicolumn{2}{|c|}{ Low sites (<1.74 mg/L) } & \multicolumn{2}{|c|}{ Medium sites (>1.74 - <7.80 mg/L) } & \multicolumn{2}{|c|}{ High sites (>7.80 mg/L) } \\
\hline Taxa & Mean & Taxa & Mean & Taxa & Mean \\
\hline Nitzschia inconspicua & 9.49 & Amphora pediculus & 9.43 & Navicula cryptotenella & 6.37 \\
\hline Amphora pediculus & 8.99 & Rhoicosphenia abbreviata & 5.14 & Nitzschia inconspicua & 5.20 \\
\hline Rhoicosphenia abbreviata & 6.33 & Navicula cryptotenella & 5.04 & Amphora pediculus & 5.15 \\
\hline Reimeria sinuata f. antiqua & 5.00 & Navicula minima & 4.57 & Navicula minima & 3.63 \\
\hline $\begin{array}{l}\text { Achnanthidium } \\
\text { minutissimum }\end{array}$ & 3.73 & Nitzschia inconspicua & 4.55 & Nitzschia amphibia & 3.49 \\
\hline Cocconeis pediculus & 3.71 & Nitzschia dissipata & 3.30 & Gomphonema minutum & 2.89 \\
\hline $\begin{array}{l}\text { Cocconeis placentula } \\
\quad \text { var. euglypta }\end{array}$ & 3.64 & Cyclotella meneghiniana & 3.18 & Navicula subminuscula & 2.82 \\
\hline $\begin{array}{l}\text { Unknown Cyanophyte } \\
\text { Oscillatoriales (sheath) }\end{array}$ & 3.19 & $\begin{array}{l}\text { Cocconeis placentula } \\
\text { var. lineata }\end{array}$ & 3.16 & $\begin{array}{l}\text { Cocconeis placentula } \\
\text { var. euglypta }\end{array}$ & 2.44 \\
\hline Cymbella affinis & 2.62 & Navicula recens & 3.13 & Rhoicosphenia abbreviata & 2.44 \\
\hline Navicula cryptotenella & 2.26 & Amphora inariensis & 1.86 & Nitzschia palea & 2.40 \\
\hline Gomphonema minutum & 2.21 & Cymbella atomus & 1.82 & Cyclotella meneghiniana & 2.27 \\
\hline Amphora inariensis & 1.81 & Navicula subminuscula & 1.49 & $\begin{array}{l}\text { Cocconeis placentula } \\
\text { var. lineata }\end{array}$ & 2.24 \\
\hline $\begin{array}{l}\text { Unknown Cyanophyte } \\
\text { Oscillatoriales (no sheath) }\end{array}$ & 1.56 & Gomphonema kobayasii & 1.43 & Nitzschia dissipata & 1.76 \\
\hline Navicula capitatoradiata & 1.34 & Nitzschia palea & 1.37 & Gomphonema kobayasii & 1.71 \\
\hline Nitzschia dissipata & 1.20 & Gomphonema minutum & 1.22 & Navicula symmetrica & 1.70 \\
\hline \multirow[t]{8}{*}{ Navicula tripunctata } & 1.11 & Nitzschia amphibia & 1.13 & Mayamaea atomus & 1.60 \\
\hline & & Navicula tripunctata & 1.11 & Simonsenia delognei & 1.47 \\
\hline & & Melosira varians & 1.04 & Navicula erifuga & 1.41 \\
\hline & & Navicula gregaria & 1.04 & Nitzschia palea var. debilis & 1.40 \\
\hline & & & & Navicula germainii & 1.34 \\
\hline & & & & Nitzschia frustulum & 1.24 \\
\hline & & & & Craticula molestiformis & 1.17 \\
\hline & & & & Navicula tripunctata & 1.13 \\
\hline Total top 5 species & 33.54 & & 28.72 & & 23.83 \\
\hline
\end{tabular}


Table 8. Most abundant algal taxa in the total nitrogen and total phosphorus nutrient categories in the Central and Western Plains and Glacial North diatom ecoregions.-Continued

[mg/L, milligrams per liter; Mean, mean relative abundance for each taxa or species within each nutrient category]

\begin{tabular}{|c|c|c|c|c|c|}
\hline \multicolumn{6}{|c|}{ Glacial North diatom ecoregion - Total nitrogen } \\
\hline \multicolumn{2}{|c|}{ Low sites $(<0.60 \mathrm{mg} / \mathrm{L})$} & \multicolumn{2}{|c|}{ Medium sites (>0.60 - <2.08 mg/L) } & \multicolumn{2}{|c|}{ High sites (>2.08 mg/L) } \\
\hline Taxa & Mean & Taxa & Mean & Taxa & Mean \\
\hline $\begin{array}{l}\text { Achnanthidium } \\
\text { minutissimum }\end{array}$ & 21.71 & Amphora pediculus & 9.65 & Amphora pediculus & 20.64 \\
\hline $\begin{array}{l}\text { Staurosira construens } \\
\text { var. venter }\end{array}$ & 5.15 & Nitzschia inconspicua & 6.52 & Navicula tripunctata & 10.87 \\
\hline Staurosirella pinnata & 3.92 & Rhoicosphenia abbreviata & 4.64 & Navicula cryptotenella & 8.07 \\
\hline Achnanthidium deflexum & 3.63 & Navicula cryptotenella & 4.01 & Rhoicosphenia abbreviata & 4.88 \\
\hline Gomphonema pumilum & 2.94 & Navicula minima & 3.73 & $\begin{array}{l}\text { Achnanthidium } \\
\text { minutissimum }\end{array}$ & 4.45 \\
\hline $\begin{array}{l}\text { Pseudostaurosira } \\
\text { brevistriata }\end{array}$ & 2.88 & Navicula tripunctata & 2.72 & Gomphonema olivaceum & 3.50 \\
\hline Fragilaria vaucheriae & 2.62 & Cyclotella meneghiniana & 2.18 & Nitzschia inconspicua & 3.48 \\
\hline Cymbella affinis & 2.57 & Nitzschia dissipata & 2.17 & Navicula minima & 2.95 \\
\hline $\begin{array}{l}\text { Staurosira construens } \\
\quad \text { var. venter }\end{array}$ & 1.82 & $\begin{array}{l}\text { Achnanthidium } \\
\text { minutissimum }\end{array}$ & 1.89 & Nitzschia dissipata & 2.61 \\
\hline Homoeothrix janthina & 1.69 & $\begin{array}{l}\text { Cocconeis placentula } \\
\text { var. euglypta }\end{array}$ & 1.85 & $\begin{array}{c}\text { Navicula secreta } \\
\text { var. apiculata }\end{array}$ & 2.57 \\
\hline Gomphonema parvulum & 1.35 & Gomphonema parvulum & 1.66 & Homoeothrix janthina & 1.83 \\
\hline \multirow[t]{4}{*}{ Synedra ulna } & 1.10 & Nitzschia amphibia & 1.57 & $\begin{array}{l}\text { Unknown Rhodophyte } \\
\text { Florideophycidae } \\
\text { (chantransia) }\end{array}$ & 1.62 \\
\hline & & Cocconeis placentula & 1.41 & Planothidium rostratum & 1.09 \\
\hline & & Navicula capitatoradiata & 1.32 & $\begin{array}{l}\text { Cocconeis placentula } \\
\text { var. euglypta }\end{array}$ & 1.00 \\
\hline & & $\begin{array}{l}\text { Cocconeis placentula } \\
\quad \text { var. lineata }\end{array}$ & 1.13 & & \\
\hline Total top 5 species & 37.35 & & 28.54 & & 48.91 \\
\hline \multicolumn{6}{|c|}{ High-nutrient taxa. } \\
\hline \multicolumn{6}{|c|}{ Low-nutrient taxa. } \\
\hline \multicolumn{6}{|c|}{ Taxa common at all nutrient levels. } \\
\hline
\end{tabular}




\section{Invertebrates}

As with the algae, identification to family level for invertebrates is not specific enough to distinguish differences between low- and high-nutrient conditions. For example, the Chironimidae and Hydropsychidae include genera that are abundant in low- or high-nutrient conditions, as well as genera that are common in all nutrient conditions (Resh and Unzicker, 1975). For this section, the invertebrate taxa are identified to the lowest taxonomic level possible, with the order name first, followed by the family and genus (and species if available) italicized.

With increased disturbance in the aquatic environment, invertebrate communities may decline in abundance, diversity, and evenness of distribution; however, in some situations, there seems to be an intermediate disturbance effect whereby a small increase in disturbance increases abundance, diversity, and evenness but, past a certain point, community structure begins to diminish (Biggs, 1995; Death and Winterbourn, 1995). For invertebrates, this "intermediate disturbance hypothesis" has been explored for stream hydrology and habitat characteristics such as flooding, substrate size, and refugia (Death and Winterbourn, 1995; Townsend and others, 1997; Lake, 2000) but has not been examined as it relates to nutrients.

\section{Central and Western Plains Diatom Ecoregion}

Three taxa were indicators of conditions of the lownutrient category for both TN and TP in CWPE: Trichoptera Hydropsychidae Ceratopsyche sp., Ephemeroptera Baetidae Baetis flavistriga, and Coleoptera Psephenidae Psephenus herricki (table 9). Apart from the common taxa, two Diptera Chironomidae genera (Cricotopus sp. and Rheotanytarsus sp.) and Trichoptera Hydroptilidae Hydroptila sp. among the TP sites and the Trichoptera Hydropsychidae Cheumatopsyche sp., Ephemeroptera Caenidae Caenis sp., Coleoptera Elmidae Stenelmis sp. and Diptera Chironomidae Microtendipes sp. among the TN sites were indicative of low-nutrient conditions.

Four taxa were indicative of the high-nutrient category for TN and TP in the CWPE: two Ephemeroptera families (Heptageniidae and Leptohyphidae Tricorythodes sp.), Diptera Chironomidae Stenochironomus sp., and Trichoptera Hydropsychidae Hydropsyche sp. High-TP conditions were also favored by Trichoptera Hydropsychidae Hydropsyche bidens, whereas high-TN conditions included higher relative abundances of six other taxa: two Diptera genera (Chironomidae Tanytarsus sp. and Empididae Hemerodromia sp.), two Coleoptera Elmidae species (Stenelmis grossa and Macronychus glabratus), a Trichoptera Hydroptilidae Hydroptila sp. and a Tubificida Naididae.
In the environment of higher overall nutrient concentrations of the CWPE, there were five and six common invertebrate taxa found in all nutrient categories in the TP and TN sites, respectively, compared to only one and two in the GNE. This finding suggests that as nutrient concentrations increase, the increase fuels the ability of multiple taxa to become abundant. This increased evenness of taxa could be used as an indicator of eutrophic conditions.

\section{Glaciated North Diatom Ecoregion}

Four taxa were indicative of low-nutrient conditions in the TN and TP categories: two Trichoptera genera (Philopotamidae Chimarra sp. and Hydropsychidae Ceratopsyche sp.) and two Diptera genera (Chironomidae Tvetenia sp. and Empididae Hemerodromia sp.) (table 9). Along with these taxa were seven additional taxa commonly abundant at sites in the low-TN category: four Ephemeroptera genera (Leptophlebiidae Paraleptophlebia sp., Heptageniidae Maccaffertium sp., Heptageniidae Leucrocuta sp., and Isonychiidae Isonychia sp.), Diptera Chironomidae Micropsectra sp., Plecoptera Perlidae Acroneuria sp., and a Trichoptera Hydroptilidae Hydroptila sp. In low-TP conditions, six additional taxa were found: four Diptera Chironomidae taxa (Thienemanniella sp., Lopescladius sp., Cricotopus sp., and Constempellina brevicosta), Ephemeroptera Heptageniidae, and Coleopteran Elmidae.

Two Diptera Chironomidae genera (Polypedilum sp. and Stictochironomus sp.) and Trichoptera Hydropsychidae Cheumatopsyche sp. were indicators of the high-nutrient category for both TP and TN. Along with those three genera, two Diptera Chironomidae taxa (Orthocladiinae and Paratanytarsus sp.), two Coleoptera Elmidae genera (Optioservus sp. and Stenelmis sp.), and the Haplotaxida Naididae were indicative of the high-TP category, and two Diptera Chironomidae genera (Microtendipes sp. and Cladotanytarsus sp.), Trichoptera Glossosomatidae Protoptila sp., and Ephemeroptera Baetidae Acerpenna sp. were indicative of the high-TN category. Only one genus was commonly found in all three nutrient categories: Diptera Chironomidae Pentaneurini sp. 
Table 9. Most abundant invertebrate taxa in the total nitrogen and total phosphorus nutrient categories in the Central and Western Plains and Glacial North diatom ecoregions.

[mg/L, milligrams per liter; Mean, mean relative abundance for each taxa or species within each nutrient category]

\begin{tabular}{|c|c|c|c|c|c|}
\hline \multicolumn{6}{|c|}{ Central and Western Plains diatom ecoregion - Total phosphorus } \\
\hline \multirow{2}{*}{\multicolumn{2}{|c|}{$\frac{\text { Low sites }(<0.05 \mathrm{mg} / \mathrm{L})}{(\mathrm{n}=13)}$}} & \multirow{2}{*}{\multicolumn{2}{|c|}{$\frac{\text { Medium sites }(>0.05-<0.17 \mathrm{mg} / \mathrm{L})}{(\mathrm{n}=61)}$}} & \multirow{2}{*}{\multicolumn{2}{|c|}{$\frac{\text { High sites }(>0.17 \mathrm{mg} / \mathrm{L})}{(\mathrm{n}=30)}$}} \\
\hline & & & & & \\
\hline Taxa & Mean & Taxa & Mean & Taxa & Mean \\
\hline Ceratopsyche sp. & 14.01 & Tricorythodes $s p$ & 8.93 & Hydropsyche sp. & 12.32 \\
\hline Cheumatopsyche sp. & 12.21 & Hydropsyche sp. & 6.24 & Tricorythodes sp. & 11.68 \\
\hline Stenelmis $s p$. & 5.94 & Cheumatopsyche sp. & 5.81 & Cheumatopsyche sp. & 9.82 \\
\hline Cricotopus sp. & 5.64 & Polypedilum sp. & 5.46 & Baetis intercalaris & 9.04 \\
\hline Polypedilum sp. & 5.51 & Macronychus glabratus & 5.36 & Polypedilum sp. & 7.85 \\
\hline Baetis intercalaris & 4.98 & Baetis intercalaris & 3.94 & Stenelmis sp. & 4.00 \\
\hline Rheotanytarsus sp. & 3.93 & Rheotanytarsus sp. & 3.11 & Heptageniidae & 2.92 \\
\hline Tricorythodes sp. & 3.82 & Ceratopsyche sp. & 3.00 & Ceratopsyche sp. & 2.75 \\
\hline Hydropsyche sp. & 3.45 & Caenis sp. & 2.92 & Macronychus glabratus & 2.22 \\
\hline Hydroptila sp. & 2.80 & Stenelmis sp. & 2.82 & Hydropsyche bidens & 2.15 \\
\hline Baetis flavistriga & 2.37 & Cricotopus sp. & 2.51 & Pentaneurini & 1.45 \\
\hline Pentaneurini & 2.04 & Heptageniidae & 2.39 & Arachnida & 1.43 \\
\hline Arachnida & 1.95 & Pentaneurini & 2.00 & Rheotanytarsus sp. & 1.42 \\
\hline \multirow[t]{2}{*}{ Psephenus herricki } & 1.47 & Arachnida & 1.84 & Stenochironomus sp. & 1.19 \\
\hline & & Naididae & 1.71 & & \\
\hline Total top 5 species & 43.31 & & 31.79 & & 50.71 \\
\hline \multicolumn{6}{|c|}{ Glacial North diatom ecoregion - Total phosphorus } \\
\hline \multirow{2}{*}{\multicolumn{2}{|c|}{$\frac{\text { Low sites }(<0.01 \mathrm{mg} / \mathrm{L})}{(\mathrm{n}=8)}$}} & \multicolumn{2}{|c|}{$\frac{\text { Medium sites }(>0.01-<0.13 \mathrm{mg} / \mathrm{L})}{(\mathrm{n}=47)}$} & \multirow{2}{*}{\multicolumn{2}{|c|}{$\begin{array}{c}\text { High sites }(>0.13 \mathrm{mg} / \mathrm{L}) \\
(\mathrm{n}=20)\end{array}$}} \\
\hline & & $(n=47)$ & & & \\
\hline Taxa & Mean & Taxa & Mean & Taxa & Mean \\
\hline Heptageniidae & 8.17 & Tubificida & 5.66 & Orthocladiinae & 11.58 \\
\hline Simulium sp. & 7.57 & Polypedilum sp. & 5.66 & Microtendipes sp. & 9.25 \\
\hline Tvetenia sp. & 5.94 & Cheumatopsyche sp. & 5.60 & Cheumatopsyche sp. & 7.10 \\
\hline Chimarra sp. & 5.80 & Rheotanytarsus sp. & 4.55 & Polypedilum sp. & 6.83 \\
\hline Elmidae & 2.94 & Orthocladiinae & 4.06 & Tubificida & 5.78 \\
\hline Polypedilum sp. & 2.82 & Hydropsyche sp. & 3.78 & Stictochironomus sp. & 4.98 \\
\hline Hemerodromia sp. & 2.69 & Cricotopus sp. & 3.67 & Baetis flavistriga & 4.70 \\
\hline Ceratopsyche sp. & 2.31 & Naididae & 3.58 & Naididae & 4.63 \\
\hline Nematoda & 2.24 & Baetis intercalaris & 2.42 & Optioservus sp. & 3.46 \\
\hline Thienemanniella sp. & 2.01 & Arachnida & 2.29 & Paratanytarsus sp. & 3.45 \\
\hline Eukiefferiella sp. & 1.89 & Pentaneurini & 2.13 & Simulium sp. & 2.79 \\
\hline Lopescladius sp. & 1.65 & Ceratopsyche sp. & 2.02 & Eukiefferiella sp. & 2.55 \\
\hline Hydroptila sp. & 1.49 & Caenis sp. & 1.95 & Stenelmis $s p$. & 1.65 \\
\hline Baetis flavistriga & 1.46 & Stenelmis sp. & 1.62 & Nematoda & 1.61 \\
\hline Pentaneurini & 1.41 & Tanytarsus sp. & 1.29 & Pentaneurini & 1.30 \\
\hline Rheotanytarsus sp. & 1.29 & & & & \\
\hline Arachnida & 1.22 & & & & \\
\hline Microtendipes sp. & 1.19 & & & & \\
\hline Constempellina brevicosta & 1.16 & & & & \\
\hline Cricotopus sp. & 1.08 & & & & \\
\hline Total top 5 species & 30.42 & & 25.53 & & 40.54 \\
\hline
\end{tabular}




\section{Assessment of Nutrient Enrichment in Wadeable Streams in Ecoregions surrounding the Great Lakes}

Table 9. Most abundant invertebrate taxa in the total nitrogen and total phosphorus nutrient categories in the Central and Western Plains and Glacial North diatom ecoregions.-Continued

[mg/L, milligrams per liter; Mean, mean relative abundance for each taxa or species within each nutrient category]

\begin{tabular}{|c|c|c|c|c|c|}
\hline \multicolumn{6}{|c|}{ Central and Western Plains diatom ecoregion - Total nitrogen } \\
\hline \multirow{2}{*}{\multicolumn{2}{|c|}{$\begin{array}{c}\text { Low sites }(<1.74 \mathrm{mg} / \mathrm{L}) \\
(\mathrm{n}=11)\end{array}$}} & \multirow{2}{*}{\multicolumn{2}{|c|}{$\begin{array}{c}\text { Medium sites }(>1.74-<7.80 \mathrm{mg} / \mathrm{L}) \\
\underline{(\mathrm{n}=57)}\end{array}$}} & \multirow{2}{*}{\multicolumn{2}{|c|}{$\begin{array}{c}\text { High sites }(>7.80 \mathrm{mg} / \mathrm{L}) \\
\underline{(\mathrm{n}=36)}\end{array}$}} \\
\hline & & & & & \\
\hline Taxa & Mean & Taxa & Mean & Taxa & Mean \\
\hline Cheumatopsyche sp. & 12.74 & Cheumatopsyche sp. & 9.19 & Tricorythodes sp. & 14.61 \\
\hline Ceratopsyche sp. & 10.92 & Tricorythodes sp. & 6.88 & Hydropsyche sp. & 10.31 \\
\hline Stenelmis sp. & 7.99 & Polypedilum sp. & 6.55 & Macronychus glabratus & 7.07 \\
\hline Caenis sp. & 6.66 & Hydropsyche sp. & 6.52 & Baetis intercalaris & 5.84 \\
\hline Polypedilum sp. & 6.29 & Baetis intercalaris & 5.63 & Polypedilum sp. & 5.48 \\
\hline Hydropsyche sp. & 4.77 & Ceratopsyche sp. & 3.82 & Cheumatopsyche sp. & 4.00 \\
\hline Baetis intercalaris & 4.11 & Cricotopus sp. & 3.45 & Heptageniidae & 3.51 \\
\hline Pentaneurini & 3.03 & Stenelmis sp. & 3.30 & Ceratopsyche sp. & 3.05 \\
\hline Baetis flavistriga & 2.77 & Rheotanytarsus sp. & 2.96 & Stenelmis sp. & 2.59 \\
\hline Baetis sp. & 2.65 & Macronychus glabratus & 2.40 & Rheotanytarsus sp. & 2.40 \\
\hline Rheotanytarsus sp. & 2.58 & Tubificida & 2.39 & Pentaneurini & 2.04 \\
\hline Cricotopus sp. & 2.43 & Caenis sp. & 2.29 & Naididae & 1.88 \\
\hline Tricorythodes sp. & 2.39 & Arachnida & 1.69 & Tanytarsus sp. & 1.83 \\
\hline Arachnida & 2.30 & Pentaneurini & 1.49 & Stenochironomus sp. & 1.76 \\
\hline Tubificida & 2.03 & Naididae & 1.32 & Arachnida & 1.64 \\
\hline Psephenus herricki & 1.74 & Leucrocuta sp. & 1.12 & Stenelmis grossa & 1.40 \\
\hline \multirow[t]{3}{*}{ Microtendipes sp. } & 1.14 & & & Cricotopus sp. & 1.27 \\
\hline & & & & Hydroptila sp. & 1.22 \\
\hline & & & & Hemerodromia sp. & 1.07 \\
\hline Total top 5 species & 44.60 & & 34.77 & & 43.32 \\
\hline
\end{tabular}


Table 9. Most abundant invertebrate taxa in the total nitrogen and total phosphorus nutrient categories in the Central and Western Plains and Glacial North diatom ecoregions.-Continued

[mg/L, milligrams per liter; Mean, mean relative abundance for each taxa or species within each nutrient category]

\begin{tabular}{|c|c|c|c|c|c|}
\hline \multicolumn{6}{|c|}{ Glacial North diatom ecoregion - Total nitrogen } \\
\hline \multirow{2}{*}{\multicolumn{2}{|c|}{$\begin{array}{c}\text { Low sites }(<0.60 \mathrm{mg} / \mathrm{L}) \\
\underline{(\mathrm{n}=13)}\end{array}$}} & \multirow{2}{*}{\multicolumn{2}{|c|}{$\begin{array}{c}\text { Medium sites }(>0.60-<2.08 \mathrm{mg} / \mathrm{L}) \\
\underline{(\mathrm{n}=43)}\end{array}$}} & \multirow{2}{*}{\multicolumn{2}{|c|}{$\begin{array}{c}\text { High sites }(>2.08 \mathrm{mg} / \mathrm{L}) \\
\underline{(\mathrm{n}=16)}\end{array}$}} \\
\hline & & & & & \\
\hline Taxa & Mean & Taxa & Mean & Taxa & Mean \\
\hline Orthocladiinae & 7.87 & Tubificida & 7.89 & Orthocladiinae & 13.16 \\
\hline Chimarra sp. & 6.37 & Cheumatopsyche sp. & 5.73 & Cheumatopsyche sp. & 8.63 \\
\hline Polypedilum sp. & 4.40 & Polypedilum sp. & 5.58 & Polypedilum sp. & 7.47 \\
\hline Paraleptophlebia sp. & 3.35 & Naididae & 4.93 & Microtendipes sp. & 6.76 \\
\hline Simulium sp. & 3.25 & Rheotanytarsus sp. & 4.74 & Baetis flavistriga & 5.77 \\
\hline Stenelmis sp. & 2.92 & Hydropsyche sp. & 4.14 & Optioservus sp. & 5.08 \\
\hline Tvetenia sp. & 2.83 & Cricotopus sp. & 3.64 & Simulium sp. & 3.47 \\
\hline Rheotanytarsus sp. & 2.61 & Hyalella azteca & 3.20 & Eukiefferiella sp. & 2.95 \\
\hline Maccaffertium sp. & 2.45 & Baetis intercalaris & 2.63 & Stictochironomus sp. & 2.71 \\
\hline Ceratopsyche sp. & 2.38 & Microtendipes sp. & 2.12 & Naididae & 2.70 \\
\hline Baetis flavistriga & 2.36 & Pentaneurini & 2.02 & Tubificida & 2.43 \\
\hline Optioservus sp. & 2.07 & Caecidotea sp. & 1.86 & Arachnida & 2.42 \\
\hline Micropsectra sp. & 2.07 & Paratanytarsus sp. & 1.82 & Stenelmis sp. & 2.07 \\
\hline Cricotopus sp. & 2.05 & Caenis sp. & 1.79 & Protoptila sp. & 2.01 \\
\hline Acroneuria sp. & 2.05 & Arachnida & 1.68 & Nematoda & 1.77 \\
\hline Nematoda & 1.98 & Tricorythodes sp. & 1.67 & Plecoptera & 1.75 \\
\hline Leucrocuta sp. & 1.90 & Ceratopsyche $s p$. & 1.58 & Pentaneurini & 1.55 \\
\hline Pentaneurini & 1.66 & & & Acerpenna sp. & 1.51 \\
\hline Cheumatopsyche sp. & 1.63 & & & Caecidotea sp. & 1.43 \\
\hline Arachnida & 1.56 & & & Cladotanytarsus sp. & 1.12 \\
\hline Hydroptila sp. & 1.46 & & & & \\
\hline Hemerodromia sp. & 1.20 & & & & \\
\hline Isonychia sp. & 1.02 & & & & \\
\hline Eukiefferiella sp. & 1.01 & & & & \\
\hline Total top 5 species & 25.23 & & 28.87 & & 41.80 \\
\hline
\end{tabular}

High-nutrient taxa.

Low-nutrient taxa.

Taxa common at all nutrient levels. 
Fish

Fish are larger than invertebrates and algae, which makes identification to species easier in the field and limits the need for laboratory verification. Although identification below family level is relatively easy (unlike algae and invertebrates), it is possible to find whole families that have relatively similar tolerances to disturbances; for example, trout (in the family Salmonidae) are considered intolerant of disturbance. For some families, however, it is necessary to look at lower taxonomic levels; for example, the Cyprinidae, which range from the very tolerant Cyprinus carpio (common carp) to the sensitive Exoglossum laurae (tonguetied minnow).

Although fish do not directly utilize nutrients, nutrients are needed to support the base of their food web. The nutrients support the algae, which feed the invertebrates and smaller fish which, in turn serve as food for the larger fish. In oligotrophic conditions, there generally is not enough food at the base of the food web. Excessive nutrients in eutrophic streams may cause an algal bloom that can consume DO when the algae die, cause toxic blooms, and cover nesting areas.

\section{Central and Western Plains Diatom Ecoregion}

Three species, Campostoma anomalum (central stoneroller), Semotilus atromaculatus (creek chub), and Rhinichthys atratulus (blacknose dace), were indicators of low nutrients for the TN and TP categories in the CWPE (table 10). Additionally, Luxilus chrysocephalus (striped shiner) and Moxostoma duquesnii (black redhorse) were indicator species in the low-TP category, and Luxilus cornutus (common shiner) and Rhinichthys cataractae (longnose dace) were indicator species in the low-TN category. Despite our classifying the study area into two regions to account for regional biotic differences, there appears to still be a north-south or coldwater-warmwater artifact within the CWPE fish community. The longnose dace is typically found in northern or montane regions (Barnes and others, 1985) and the common shiner generally prefers cooler waters and is often replaced by the striped shiner as streams become warmer (eNature. com, 2009). Within the low-nutrient category, three of the sites were in Indiana or Ohio, and one was in Minnesota. The common shiner and longnose dace dominated the Minnesota site, whereas the striped shiner was dominant in the Indiana and Ohio sites.

Within the CWPE, Cyprinella spiloptera (spotfin shiner) and Notropis stramineus (sand shiner) were indicator species in the high-TN and high-TP categories. Additionally, Lepomis cyanellus (green sunfish), Lepomis macrochirus (bluegill), Pimephales promelas (fathead minnow), common carp, and Ameiurus natalis (yellow bullhead) were indicator species in the high-TP category and the Hybopsis dorsalis (bigmouth shiner), Moxostoma erythrurum (golden redhorse), Cyprinella lutrensis (red shiner), and Moxostoma macrolepidotum (shorthead redhorse) were indicator species in the high-TN category. Like the longnose dace and common shiners in low-TP conditions, the bigmouth shiner (McCulloch, 2003) and red shiner (Messaad and others, 2000) prefer cooler water temperatures. Three indicator species in the high-TP category are species that can withstand low DO concentrations (green sunfish, fathead minnow, and common carp). The Catostomus commersonii (white sucker) and Pimephales notatus (bluntnose minnow) were commonly found within all nutrient categories for TN and TP within the CWPE.

\section{Glaciated North Diatom Ecoregion}

Within the GNE, Salmo trutta (brown trout) and Cottus $s p$. (freshwater sculpins) were indicator species in the low-TP and low-TN categories along with Cottus bairdii (mottled sculpin), longnose dace, and Lota lota (burbot) in the low-TP category and common shiner, Nocomis biguttatus (hornyhead chub), and mottled sculpin in the low-TN category (table 10). All of the low-nutrient indicator fish species are commonly found in cool or cold water. Etheostoma nigrum (johnny darter), Umbra limi (central mudminnow), Etheostoma duryi (blackside darter), and common carp were indicator species in the high-TP and high-TN categories, along with creek chub and Culaea inconstans (brook stickleback) in the high-TP category and green sunfish in the high-TN category. Three species in the GNE-brook stickleback, central mudminnow (Klinger and others, 1982), and common carp - are able to withstand low-DO concentrations, similar to the species found within the high-TP conditions in the CWPE. The high number of indicator species for low TP within the CWPE and GNE capable of surviving in low-DO conditions suggests that the sites with low phosphorus concentrations may be influenced by increased algal growth and subsequent senescence, which leads to low-DO conditions. Within the GNE, white sucker was commonly found within all nutrient conditions for both $\mathrm{TN}$ and TP, along with blacknose dace and common shiner for $\mathrm{TP}$ and creek chub for TN. 
Table 10. Most relative abundant fish species in the total nitrogen and total phosphorus nutrient categories in the Central and Western Plains and Glacial North diatom ecoregions.

[mg/L, milligrams per liter; Mean, mean relative abundance for each taxa or species within each nutrient category]

\begin{tabular}{|c|c|c|c|c|c|}
\hline \multicolumn{6}{|c|}{ Central and Western Plains diatom ecoregion - Total phosphorus } \\
\hline \multirow{2}{*}{\multicolumn{2}{|c|}{$\begin{array}{c}\text { Low sites }(<0.05 \mathrm{mg} / \mathrm{L}) \\
\qquad \underline{(\mathrm{n}=13)}\end{array}$}} & \multirow{2}{*}{\multicolumn{2}{|c|}{$\begin{array}{c}\text { Medium sites }(>0.05-<0.17 \mathrm{mg} / \mathrm{L}) \\
(\mathrm{n}=61)\end{array}$}} & \multirow{2}{*}{\multicolumn{2}{|c|}{$\begin{array}{c}\text { High sites }(>0.17 \mathrm{mg} / \mathrm{L}) \\
\underline{(\mathrm{n}=30)}\end{array}$}} \\
\hline & & & & & \\
\hline central stoneroller & 21.25 & spotfin shiner & 8.76 & spotfin shiner & 15.00 \\
\hline bluntnose minnow & 12.14 & bluntnose minnow & 8.03 & bluntnose minnow & 13.10 \\
\hline common shiner & 6.30 & green sunfish & 5.76 & green sunfish & 9.82 \\
\hline sand shiner & 4.76 & white sucker & 5.36 & bluegill & 6.26 \\
\hline blacknose dace & 4.04 & central stoneroller & 5.09 & fathead minnow & 5.63 \\
\hline hornyhead chub & 3.10 & creek chub & 4.26 & common carp & 4.87 \\
\hline striped shiner & 2.82 & golden redhorse & 3.90 & white sucker & 2.64 \\
\hline white sucker & 2.26 & & & & \\
\hline golden redhorse & 2.06 & & & & \\
\hline Total top 5 species & 56.29 & & 33.83 & & 54.98 \\
\hline \multicolumn{6}{|c|}{ Glacial North diatom ecoregion - Total phosphorus } \\
\hline \multicolumn{2}{|c|}{ Low sites $(<0.01 \mathrm{mg} / \mathrm{L})$} & \multicolumn{2}{|c|}{ Medium sites $(>0.01-<0.13 \mathrm{mg} / \mathrm{L})$} & \multicolumn{2}{|c|}{ High sites (>0.13 mg/L) } \\
\hline \multicolumn{2}{|c|}{$(n=8)$} & \multicolumn{2}{|c|}{$\underline{(n=47)}$} & \multicolumn{2}{|c|}{$\underline{(n=20)}$} \\
\hline Species & Mean & Species & Mean & Species & Mean \\
\hline mottled sculpin & 19.42 & common shiner & 11.23 & johnny darter & 27.66 \\
\hline longnose dace & 12.93 & white sucker & 10.76 & creek chub & 11.58 \\
\hline \multirow[t]{4}{*}{ johnny darter } & 1.04 & northern hog sucker & 3.93 & hornyhead chub & 2.83 \\
\hline & & johnny darter & 2.27 & common carp & 2.79 \\
\hline & & blacknose dace & 2.17 & & \\
\hline & & bluegill & 2.01 & & \\
\hline Total top 5 species & 61.56 & & 39.52 & & 57.48 \\
\hline
\end{tabular}




\section{Assessment of Nutrient Enrichment in Wadeable Streams in Ecoregions surrounding the Great Lakes}

Table 10. Most relative abundant fish species in the total nitrogen and total phosphorus nutrient categories in the Central and Western Plains and Glacial North diatom ecoregions.-Continued

[mg/L, milligrams per liter; Mean, mean relative abundance for each taxa or species within each nutrient category]

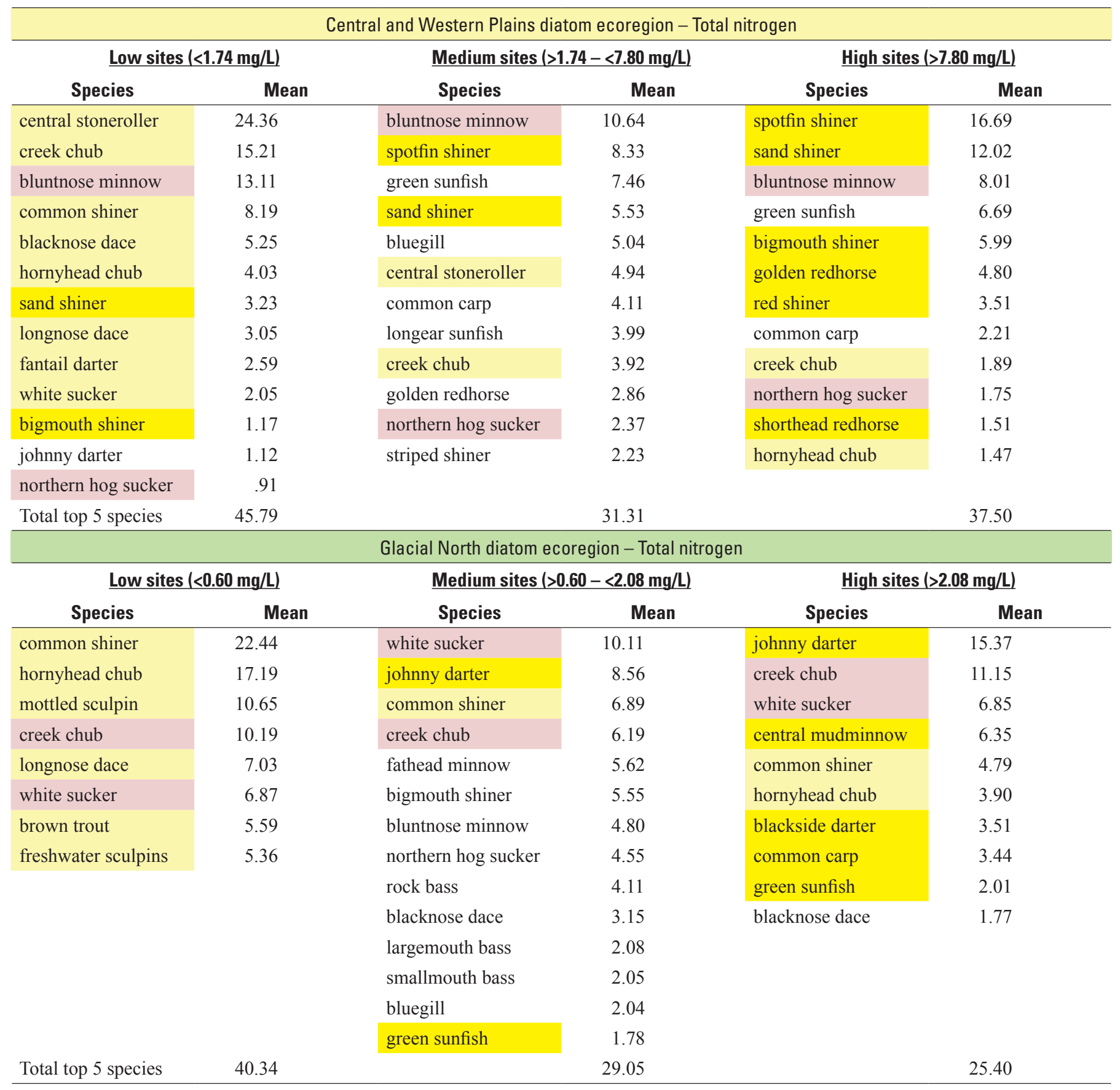

High-nutrient taxa.

Low-nutrient taxa.

Taxa common at all nutrient levels. 


\section{Breakpoint Analysis Between Nutrients and Biological Attributes}

In all biological communities, there are species that thrive in either low- or high-nutrient conditions. In this study, within each of the biological communities, certain attributes increased with increasing nutrient concentrations (positive relation), whereas others decreased with increasing nutrient concentrations (negative relation). There tended to be a wide range of breakpoints in most of the biological communities. In previous studies in Wisconsin (Robertson and others, 2008), Indiana (Caskey and others, 2010), and Kentucky (Crain and Caskey, 2010) the mean or median of breakpoints from several relations were used to determine the appropriate breakpoint for a specific State or ecoregion. In our study, instead of averaging the significant breakpoints for attributes of each biological community, the breakpoints for each biological community were associated with either low nutrient concentrations indicative of lower trophic levels (oligotrophic) or high nutrient concentrations indicative of higher trophic (eutrophic) levels. These breakpoints for specific attributes can be viewed as a gradient that can help environmental managers and researchers to assess the nutrient conditions within a stream.

Significant breakpoints were found for nutrients (TN and TP) and multiple attributes for algae, invertebrates, and fish communities within the CWPE and GNE ecoregions. In general, there were more significant breakpoints, with lower concentrations, for the GNE than for the more nutrient-rich CWPE (table 11). The significant algal attributes resulted in a wider range of breakpoints than the fish or invertebrate attributes; the invertebrate community did not have any low-TN or low-TP breakpoints in the CWPE. In general, TP correlated more strongly with all of the biological attributes than did TN.

\section{Algae}

In the CWPE, the breakpoints for TN ranged from 1.67 to $4.57 \mathrm{mg} / \mathrm{L}$ and for TP from 0.070 to $0.134 \mathrm{mg} / \mathrm{L}$ (table 11 ). The correlations with algal attributes were stronger for TP than for TN. The lowest breakpoint for TN was with the percent diatoms that are beta mesosaprobic ${ }^{l}$ attribute and for TP was with the abundance of diatoms preferring meso-eutrophic conditions attribute. The highest breakpoint for $\mathrm{TN}$ was the percent diatoms indicative of elevated concentrations of organically bound nitrogen and breakpoints for TP were the richness of pollution sensitive diatoms (Bahls) and percent beta-mesosaprobic diatoms attributes. Three of the four algal attributes had positive correlations with TN (increased as TN concentrations increased), whereas four of five algal attributes had negative correlations with TP (decreased as TP concentrations increased).

\footnotetext{
${ }^{1}$ Italic type is used simply to aid readability of the rather lengthy attribute names. No special emphasis is intended.
}

In the GNE, the breakpoints for TN ranged from 0.63 to $1.32 \mathrm{mg} / \mathrm{L}$ and for TP from 0.020 to $0.100 \mathrm{mg} / \mathrm{L}$ (table 11 ). The correlations with algal attributes with TN and TP were equally strong. The lowest breakpoints for TN and TP were with percent abundance of Achnanthidium minutissimum and percent richness diatoms preferring eutrophic conditions. The highest breakpoints for TN and TP were with richness of pollution sensitive diatoms (Bahls) and taxa richness. All of the algal attributes had negative correlations with TN and TP except for percent richness diatoms preferring eutrophic conditions, which increased when TN or TP increased, and taxa richness, which decreased when TN increased but decreased when TP increased.

\section{Invertebrates}

In the CWPE, the breakpoints for TN ranged from 3.28 to $8.45 \mathrm{mg} / \mathrm{L}$ and for TP from 0.092 to $0.711 \mathrm{mg} / \mathrm{L}$ (table 11). Of the three biological communities, the invertebrate breakpoints were about twice as high as the breakpoints for the algae and fish communities. The lowest breakpoint for TN was with ratio of Tanytarsini richness to midge richness and for TP with abundance of Orthocladinae midges. The highest breakpoint for $\mathrm{TN}$ is with percentage of total richness composed of bivalvia and for TP with number of taxa in the intolerant class. Significant breakpoints could only be found for invertebrates at higher nutrient concentrations that reflect the higher nutrient conditions in the streams of the CWPE; no breakpoints were associated with the low nutrient concentrations such as were found in the GNE.

In the GNE, the breakpoints for TN ranged from 0.52 to $1.12 \mathrm{mg} / \mathrm{L}$ and for TP from 0.020 to $0.064 \mathrm{mg} / \mathrm{L}$ (table 11). The lowest breakpoint for TN was with richness composed of predators and for TP was with richness composed of midges; however, concentrations for six of the significant breakpoints for TP were relatively low (between 0.020 and $0.025 \mathrm{mg} / \mathrm{L}$ ). The highest breakpoints for TN were for richness composed of filtering-collectors and richness composed of Tanytarsini midges; for TP, the highest breakpoint was with richness composed of Tanytarsini midges. All of the invertebrate attributes had negative correlations with TN and TP except for percentage of taxa richness in the moderately tolerant class, which increased when TN or TP increased. 
Table 11. Breakpoints between nutrients and the most significant biological metrics in the Central and Western Plains and Glacial North diatom ecoregions.

[mg/L, milligrams per liter; \%, percent; NS, not significant; Neg, negative; Pos, positive; DO, dissolved oxygen; Bold indicates a $p$ value $<0.05$

\begin{tabular}{|c|c|c|c|c|c|c|c|c|c|c|c|}
\hline \multirow[b]{2}{*}{$\begin{array}{c}\text { Attribute } \\
\text { (Note: All algae } \\
\text { attributes are for } \\
\text { diatoms) }\end{array}$} & \multirow[b]{2}{*}{$\begin{array}{l}\text { Number } \\
\text { of } \\
\text { samples }\end{array}$} & \multicolumn{5}{|c|}{ Total nitrogen } & \multicolumn{5}{|c|}{ Total phosphorus } \\
\hline & & $\begin{array}{c}\text { Breakpoint } \\
\text { concentration } \\
(\mathrm{mg} / \mathrm{L})\end{array}$ & p-value & $\begin{array}{l}\text { Lower } 5 \% \\
\text { confidence } \\
\text { interval } \\
(\mathrm{mg} / \mathrm{L})\end{array}$ & $\begin{array}{l}\text { Upper } 5 \% \\
\text { confidence } \\
\text { interval } \\
\text { (mg/L) }\end{array}$ & $\begin{array}{l}\text { Correlation } \\
\text { type }\end{array}$ & $\begin{array}{c}\text { Breakpoint } \\
\text { concentration } \\
(\mathrm{mg} / \mathrm{L})\end{array}$ & p-value & $\begin{array}{l}\text { Lower } 5 \% \\
\text { confidence } \\
\text { interval } \\
(\mathrm{mg} / \mathrm{L})\end{array}$ & $\begin{array}{l}\text { Upper } 5 \% \\
\text { confidence } \\
\text { interval } \\
\text { (mg/L) }\end{array}$ & $\begin{array}{c}\text { Correlation } \\
\text { type }\end{array}$ \\
\hline \multicolumn{12}{|c|}{ Central and Western Plains diatom ecoregion } \\
\hline \multicolumn{12}{|c|}{ Algae } \\
\hline $\begin{array}{l}\text { Percent pollution sensitive } \\
\text { diatoms (Bahls) }\end{array}$ & 104 & NS & 0.216 & NS & NS & NS & 0.133 & 0.007 & 0.064 & 0.140 & Neg \\
\hline $\begin{array}{l}\text { Percent diatoms indicative of el- } \\
\text { evated concentrations of } \\
\text { organically bound nitrogen }{ }^{1}\end{array}$ & 104 & 4.57 & .008 & 3.26 & 10.13 & Pos & .075 & .005 & .052 & .183 & Pos \\
\hline $\begin{array}{l}\text { Percent diatoms requiring } \\
\quad>30 \% \text { DO saturation }\end{array}$ & 104 & 3.28 & .021 & 1.67 & 5.49 & Pos & .082 & .003 & .052 & .092 & Neg \\
\hline $\begin{array}{l}\text { Percent beta-mesosaprobic } \\
\text { diatoms }\end{array}$ & 104 & 1.67 & .041 & 1.46 & 4.87 & Pos & .133 & .073 & .052 & .155 & Neg \\
\hline $\begin{array}{l}\text { Abundance of diatoms preferring } \\
\text { meso-eutrophic conditions }{ }^{3}\end{array}$ & 104 & 4.35 & .086 & 4.07 & 4.73 & $\mathrm{Neg}$ & .070 & .016 & .053 & .090 & Neg \\
\hline \multicolumn{12}{|c|}{ Invertebrates } \\
\hline $\begin{array}{l}\text { Percentage of total richness } \\
\text { composed of bivalvia }\end{array}$ & 104 & 8.45 & 0.032 & 3.45 & 8.80 & Neg & 0.189 & 0.004 & 0.153 & 0.711 & Pos \\
\hline $\begin{array}{l}\text { Ratio of Tanytarsanii richness } \\
\text { to midge richness }\end{array}$ & 104 & 3.28 & .021 & 1.67 & 10.13 & Neg & .141 & .001 & .075 & .192 & Neg \\
\hline $\begin{array}{l}\text { Number of taxa in the intolerant } \\
\text { class }\end{array}$ & 104 & NS & .170 & NS & NS & NS & .711 & .001 & .090 & .711 & Neg \\
\hline Abundance of Orthocladinae midges & 104 & 4.90 & .035 & 4.68 & 5.91 & Neg & .092 & .001 & .044 & .114 & Neg \\
\hline \multicolumn{12}{|c|}{ Fish } \\
\hline Number of fish & 105 & 4.73 & 0.070 & 1.24 & 6.95 & $\mathrm{Neg}$ & 0.070 & 0.001 & 0.040 & 0.080 & $\mathrm{Neg}$ \\
\hline Percent abundance of stonerollers & 105 & 1.79 & .001 & 1.24 & 4.87 & $\mathrm{Neg}$ & .070 & .001 & .039 & .070 & Neg \\
\hline Number of darters & 105 & 3.51 & .007 & 1.32 & 4.55 & Neg & NS & .210 & NS & NS & NS \\
\hline
\end{tabular}


Table 11. Breakpoints between nutrients and the most significant biological metrics in the Central and Western Plains and Glacial North diatom ecoregions.-Continued [mg/L, milligrams per liter; \%, percent; NS, not significant; Neg, negative; Pos, positive; DO, dissolved oxygen; Bold indicates a $p$ value $<0.05]$

\begin{tabular}{|c|c|c|c|c|c|c|c|c|c|c|c|}
\hline \multirow[b]{2}{*}{$\begin{array}{c}\text { Attribute } \\
\text { (Note: All algae } \\
\text { attributes are for } \\
\text { diatoms) }\end{array}$} & \multirow[b]{2}{*}{$\begin{array}{l}\text { Number } \\
\text { of } \\
\text { samples }\end{array}$} & \multicolumn{5}{|c|}{ Total nitrogen } & \multicolumn{5}{|c|}{ Total phosphorus } \\
\hline & & $\begin{array}{c}\text { Breakpoint } \\
\text { concentration } \\
\text { (mg/L) }\end{array}$ & p-value & $\begin{array}{l}\text { Lower } 5 \% \\
\text { confidence } \\
\text { interval } \\
\text { (mg/L) }\end{array}$ & $\begin{array}{l}\text { Upper } 5 \% \\
\text { confidence } \\
\text { interval } \\
\text { (mg/L) }\end{array}$ & $\begin{array}{l}\text { Correlation } \\
\text { type }\end{array}$ & $\begin{array}{c}\text { Breakpoint } \\
\text { concentration } \\
(\mathrm{mg} / \mathrm{L})\end{array}$ & p-value & $\begin{array}{l}\text { Lower } 5 \% \\
\text { confidence } \\
\text { interval } \\
(\mathrm{mg} / \mathrm{L})\end{array}$ & $\begin{array}{l}\text { Upper } 5 \% \\
\text { confidence } \\
\text { interval } \\
(\mathrm{mg} / \mathrm{L})\end{array}$ & $\begin{array}{c}\text { Correlation } \\
\text { type }\end{array}$ \\
\hline \multicolumn{12}{|c|}{ Glaciated North diatom ecoregion } \\
\hline \multicolumn{12}{|c|}{ Algae } \\
\hline $\begin{array}{l}\text { Percent abundance of } \\
\text { Achnanthidium minutissimum }\end{array}$ & 71 & 0.63 & 0.002 & 0.53 & 0.98 & Neg & 0.020 & 0.001 & 0.015 & 0.045 & $\mathrm{Neg}$ \\
\hline $\begin{array}{l}\text { Richness pollution sensitive } \\
\text { diatoms (Bahls) }\end{array}$ & 71 & 1.32 & .001 & .56 & 1.54 & $\mathrm{Neg}$ & .090 & .001 & .030 & .131 & $\mathrm{Neg}$ \\
\hline Taxa richness & 71 & 1.32 & .001 & .53 & 1.58 & Neg & .099 & .001 & .082 & .130 & Neg \\
\hline $\begin{array}{l}\text { Percent diatom taxa generally } \\
\text { intolerant to organically bound } \\
\text { nitrogen }{ }^{4}\end{array}$ & 71 & 1.20 & .008 & .43 & 1.48 & Neg & .030 & .001 & .014 & .064 & $\mathrm{Neg}$ \\
\hline $\begin{array}{l}\text { Percent diatoms requiring nearly } \\
100 \% \text { DO saturation }\end{array}$ & 71 & 1.11 & .001 & .63 & 1.32 & Neg & .030 & .001 & .014 & .060 & Neg \\
\hline $\begin{array}{l}\text { Percent richness that are } \\
\text { oligosaprobic }\end{array}$ & 71 & .98 & .001 & .63 & 1.32 & Neg & .030 & .001 & .020 & .060 & Neg \\
\hline $\begin{array}{l}\text { Percent richness diatoms preferring } \\
\text { eutrophic conditions }\end{array}$ & 71 & .63 & .001 & .53 & 1.36 & Pos & .025 & .003 & .018 & .064 & Pos \\
\hline \multicolumn{12}{|c|}{ Invertebrates } \\
\hline Richness composed of midges & 72 & 0.66 & 0.002 & 0.53 & 1.84 & Neg & 0.020 & 0.003 & 0.017 & 0.082 & Neg \\
\hline Number of clinger taxa & 72 & .63 & .001 & .56 & 1.04 & Neg & .025 & .001 & .024 & .046 & $\mathrm{Neg}$ \\
\hline $\begin{array}{l}\text { Richness composed of filtering- } \\
\text { collecters }\end{array}$ & 72 & 1.12 & .003 & .52 & 1.28 & $\mathrm{Neg}$ & .025 & .001 & .018 & .070 & Neg \\
\hline $\begin{array}{l}\text { Percentage of abundance in the } \\
\text { intolerant class }\end{array}$ & 72 & .56 & .002 & .56 & 1.20 & $\mathrm{Neg}$ & .044 & .001 & .017 & .060 & $\mathrm{Neg}$ \\
\hline $\begin{array}{l}\text { Number of taxa in the intolerant } \\
\text { class }\end{array}$ & 72 & .63 & .001 & .56 & 1.00 & Neg & .024 & .001 & .020 & .044 & Neg \\
\hline $\begin{array}{l}\text { Percentage of taxa richness in the } \\
\text { moderately tolerant class }\end{array}$ & 72 & .56 & .001 & .56 & .98 & Pos & .024 & .001 & .020 & .060 & Pos \\
\hline Richness composed of odonates & 72 & .98 & .001 & .52 & 1.58 & Neg & .046 & .001 & .017 & .090 & Neg \\
\hline Richness composed of stoneflies & 72 & .63 & .001 & .53 & .93 & Neg & .024 & .001 & .014 & .035 & Neg \\
\hline Richness composed of predators & 72 & .53 & .001 & .50 & 1.58 & Neg & .046 & .001 & .018 & .077 & Neg \\
\hline
\end{tabular}


[mg/L, milligrams per liter; \%, percent; NS, not significant; Neg, negative; Pos, positive; DO, dissolved oxygen; Bold indicates a $p$ value $<0.05$ ]

\begin{tabular}{|c|c|c|c|c|c|c|c|c|c|c|c|}
\hline \multirow[b]{2}{*}{$\begin{array}{c}\text { Attribute } \\
\text { (Note: All algae } \\
\text { attributes are for } \\
\text { diatoms) }\end{array}$} & \multirow[b]{2}{*}{$\begin{array}{l}\text { Number } \\
\text { of } \\
\text { samples }\end{array}$} & \multicolumn{5}{|c|}{ Total nitrogen } & \multicolumn{5}{|c|}{ Total phosphorus } \\
\hline & & $\begin{array}{c}\text { Breakpoint } \\
\text { concentration } \\
\text { (mg/L) }\end{array}$ & p-value & $\begin{array}{c}\text { Lower } 5 \% \\
\text { confidence } \\
\text { interval } \\
(\mathrm{mg} / \mathrm{L})\end{array}$ & $\begin{array}{c}\text { Upper 5\% } \\
\text { confidence } \\
\text { interval } \\
\text { (mg/L) }\end{array}$ & $\begin{array}{l}\text { Correlation } \\
\text { type }\end{array}$ & $\begin{array}{c}\text { Breakpoint } \\
\text { concentration } \\
(\mathrm{mg} / \mathrm{L})\end{array}$ & p-value & $\begin{array}{l}\text { Lower } 5 \% \\
\text { confidence } \\
\text { interval } \\
\text { (mg/L) }\end{array}$ & $\begin{array}{c}\text { Upper 5\% } \\
\text { confidence } \\
\text { interval } \\
\text { (mg/L) }\end{array}$ & $\begin{array}{l}\text { Correlation } \\
\text { type }\end{array}$ \\
\hline \multicolumn{12}{|c|}{ Glaciated North diatom ecoregion-continued } \\
\hline \multicolumn{12}{|c|}{ Fish } \\
\hline $\begin{array}{l}\text { Richness composed of Tanytarsanii } \\
\text { midges }\end{array}$ & 72 & 1.12 & 0.002 & 0.63 & 1.68 & Neg & 0.064 & 0.001 & 0.020 & 0.077 & Neg \\
\hline Percent abundance of darters & 64 & 2.46 & .013 & 1.28 & 2.46 & Pos & .137 & .001 & .098 & .170 & Neg \\
\hline $\begin{array}{l}\text { Percent abundance of piscivorous } \\
\text { fish }\end{array}$ & 64 & NS & .169 & NS & NS & NS & .070 & .081 & .020 & .130 & $\mathrm{Neg}$ \\
\hline Percent abundance of sensitive fish & 64 & .63 & .004 & .53 & 1.10 & Neg & .046 & .001 & .020 & .060 & Neg \\
\hline Percent abundance of tolerant fish & 64 & NS & .510 & NS & NS & NS & .060 & .002 & .035 & .070 & Pos \\
\hline
\end{tabular}

\section{${ }^{1}$ Obligate heterotrophs.}

${ }^{2}$ Saprobic class: II - (02 saturation: 70-80\%; BOD5: 2-4 mg/L).

${ }^{3}$ Beta-mesosaprobic: somewhat degraded conditions, mesotrophic-eutrophic.

${ }^{4}$ May be "oligotrophic" or "mesotrophic species (autotroph).

${ }^{5}$ Saprobic classes: I, I-II - (O2 saturation: > 85\%; BOD5: <2 mg/L). 
Fish

In the CWPE, the breakpoints for TN ranged from 1.79 to $4.73 \mathrm{mg} / \mathrm{L}$; for TP, both significant breakpoints were $0.070 \mathrm{mg} / \mathrm{L}$ (table 11). The lowest breakpoint for TN was with percent abundance of stonerollers; for TP, the lowest breakpoints were with percent abundance of stonerollers and number of fish. The highest breakpoint for TN was with number of fish. Fewer significant attributes were found for fish than for algae or invertebrates. All of the fish attributes had negative correlations with TN and TP. The number of fish attribute indicated that the numbers of fish decrease as concentrations of TN and TP increase; however, the breakpoint for TN was relatively high $(4.73 \mathrm{mg} / \mathrm{L})$, whereas the breakpoint for TP was moderate $(0.070 \mathrm{mg} / \mathrm{L})$ compared to the breakpoints found for fish in the GNE.

In the GNE, the two significant breakpoints for TN were 0.63 and $2.46 \mathrm{mg} / \mathrm{L}$, and the four significant breakpoints for TP ranged from 0.046 to $0.137 \mathrm{mg} / \mathrm{L}$ (table 11). The percent abundance of sensitive fish attribute had the lowest breakpoints for TN and TP. The highest breakpoints for both TN and TP were with percent abundance of darters.

The darter attributes were significant in both the CWPE and GNE ecoregions. Because darters were significant in both ecoregions, and if the entire region is considered together, the darter attribute appears to show a threshold from positive to negative (bell-shaped) response. In the lower nutrient conditions of the GNE, darter abundance increases with increasing $\mathrm{TN}$, with a breakpoint of $2.46 \mathrm{mg} / \mathrm{L}$. In the higher nutrient conditions of the CWPE, darter abundance decreases with increasing nutrients, with a breakpoint of $3.51 \mathrm{mg} / \mathrm{L}$.

\section{Management Implications}

Although the geographic area of our study generally encompasses regional divisions used by the USEPA (U.S. Environmental Protection Agency, 2010) and the USGS (U.S. Geological Survey, 2010), there are distinct differences between the northern and southern parts. The southern States in the study area (Illinois, Indiana, Iowa, and Ohio) are dominated by row-crop agriculture, primarily corn and soybeans, which requires the additions of large amounts of fertilizer and manure to maximize crop yields. These cornbelt States have the greatest inputs of $\mathrm{N}$ and $\mathrm{P}$ in the country (Mueller and Spahr, 2006). Consequently, some of the highest nutrient concentrations are found in streams in these southern States (Mueller and Spahr, 2006; Lorenz and others, 2009), and these streams ultimately are the source of greatest nutrient loadings to the Gulf of Mexico (Goolsby and others, 2001; Alexander and others, 2008). In the northern States in the study area (Minnesota, Wisconsin, and Michigan), agriculture also is extensive; however, these States tend to have more forested areas mixed in with the row crops and less corn production overall. The higher concentrations found in our study in streams in the CWPE compared to the GNE (figs. 4 and 5) support findings from the studies listed above. The biological communities also were significantly different between the northern and southern parts of the study area. Some of the differences in the biological communities between the northern and southern states is due to stream temperature: streams are typically warmwater in the south and coolwater or coldwater in the north. In this study, the diatom ecoregions developed by Potapova and Charles (2007) were used to account for the regional differences. This distinction seemed to work well for the invertebrate and fish communities; however, some coldwater fish species were abundant in the northern parts of the southern States. For these reasons, it is important when conducting stressor-response studies that regional differences in water chemistry, habitat, and biological communities be considered.

Previous studies have set boundaries of trophic levels in streams. Dodds and others (1998) used the frequency distributions of TP, TN, and CHL $a$ to determine trophic boundaries, but the boundaries were not linked to responses by the biological communities to nutrient concentrations. Dodds and others (1998) set oligotrophic-mesotrophic boundaries for TP at $0.025 \mathrm{mg} / \mathrm{L}$ and for TN at $0.7 \mathrm{mg} / \mathrm{L}$ and mesotrophic-eutrophic boundary for TP at $0.075 \mathrm{mg} / \mathrm{L}$ and for TN at $1.5 \mathrm{mg} / \mathrm{L}$. In New York, Smith and others (2007) used invertebratecommunity response to nutrient concentrations to establish trophic boundaries and found comparable boundaries for TP $(0.0175 \mathrm{mg} / \mathrm{L}$ for oligotrophic-mesotrophic and $0.065 \mathrm{mg} / \mathrm{L}$ for mesotrophic-eutrophic boundaries) and slightly lower boundaries for nitrogen $\left(0.24 \mathrm{mg} / \mathrm{L}\right.$ of $\mathrm{NO}_{3}$ for oligotrophicmesotrophic and $0.98 \mathrm{mg} / \mathrm{L}$ of $\mathrm{NO}_{3}$ for mesotrophic-eutrophic boundaries). The boundaries in these two studies cannot be directly related because of the differences in forms of nitrogen, $\mathrm{TN}$ and $\mathrm{NO}_{3}$; however, an estimate of $\mathrm{TN}$ can be made by using the ratio of $\mathrm{NO}_{3}$ to $\mathrm{TN}$ as a conversion factor. In this study, the median $\mathrm{NO}_{3}$ to $\mathrm{TN}$ ratio value was about 0.70 , and if the $\mathrm{NO}_{3}$ values from Smith and others (2007) were thus converted to $\mathrm{TN}$, the values would become $0.34 \mathrm{mg} / \mathrm{L}$ and $1.4 \mathrm{mg} / \mathrm{L}$, respectively. The converted values are close to the Dodds and others (1998) mesotrophic-eutrophic boundary and about half of the value for the oligotrophic-mesotrophic boundary. Our dataset allowed for comparisons of differences in the breakpoints between low and high nutrient concentrations within and across diatom ecoregions. The breakpoints show the changes in the biological-community attributes along the nutrient gradient and therefore reflect the changes in trophic status better than simple trophic levels based solely on nutrient concentrations.

In general, the lower nutrient concentrations of the northern region, the GNE, compared to the southern region, the CWPE, allowed for a nutrient gradient in which species indicative of oligotrophic conditions could be distinguished. In contrast, the CWPE is nutrient saturated, and examination of the biological communities does not reveal indicator species or attributes of low nutrient concentrations. The low and high breakpoints from all biological communities were generally 
about 3-5 times higher in the south than the north (table 11). In the north (GNE), similar low breakpoints were found for $\mathrm{TN}$ with all biological communities (around $0.63 \mathrm{mg} / \mathrm{L}$ ) and for TP (between 0.02 and $0.03 \mathrm{mg} / \mathrm{L}$ ) with the algae and invertebrate communities. In the lower nutrient conditions in the streams of the GNE, the breakpoints between the fish-community attributes and TP concentrations were higher compared to those for the algae or invertebrate communities. However, Miltner and Rankin (1998) found fish IBI scores in wadeable streams of Ohio significantly decreased at concentrations greater than $0.61 \mathrm{mg} / \mathrm{L}$ of TN, and Wang and others (2007) found a similar breakpoint for TN of around $0.60 \mathrm{mg} / \mathrm{L}$. Crain and Caskey (2010) found multiple significant breakpoints between TP and invertebrate attributes between 0.032 and $0.035 \mathrm{mg} / \mathrm{L}$ in Kentucky.

Besides their relation to significant breakpoints with low nutrient concentrations in the north, the significant biological attributes were reflective of nutrient or ecological conditions (specifically, increasing percentage of eutrophic diatoms in algae, decreasing number of taxa in the intolerant class for invertebrates, and decreasing number of sensitive species in fish). There were also more attributes with significantly detectable breakpoints in the north, where the nutrient gradient was lower than that in the south. This finding suggests that as nutrients increase, the biological communities become more uniform, with fewer sensitive taxa, so significant nonlinear breakpoints cannot be determined. Additionally, the breakpoints tend to be higher and are more reflective of breakpoints between mesotrophic and eutrophic conditions.

Several studies have found that among algae, invertebrates, and fish, algal communities have the strongest relations to nutrient condition (U.S. Environmental Protection Agency, 2003; Justus and others, 2009). Yet, few States have adopted the collection of algal communities as part of their strategy to determine impaired streams. Most States use invertebrateand fish-community assessments as part of their regulatory designs; although these invertebrate- and fish-based assessments of biotic integrity are able to effectively determine whether a stream is impaired, they lack the sensitivity to determine whether nutrients cause the impairment (Smith and others, 2007). Our study supports the finding that algal-community assessments provide important information to link stream impairment to nutrients on the basis of multiple attributes with significant relations with and breakpoints for TN and TP. Invertebrate- and fish-community attributes do not necessarily have a direct link to nutrients in the same way algae do, but they appear to have the ability to distinguish breakpoints for both low and high concentrations, especially in low-nutrient regions. From our study, it appears that the invertebrate community would be less useful than the algal or fish communities in assessing low-level breakpoints in nutrient-rich areas. However, the consistently negative correlations at low breakpoint concentrations and the diverse nature of many of the TP attributes support the finding that for low-nutrient conditions, the invertebrate community is able to detect changes in nutrient levels. In the low-nutrient conditions of the GNE, the similar breakpoints from several algal and invertebrate attributes provide multiple lines of evidence and strengthen the case for using these breakpoints for nutrient criteria development in this region. In nutrient-rich areas like the CWPE, all of the breakpoints were substantially higher than for the lower nutrient conditions of the GNE and suggest that stream conditions are nutrient saturated to the point that low-end breakpoints cannot be detected. Invertebrates in particular seem to be less able to distinguish low-end breakpoints in high-nutrient conditions. Miltner and Rankin (1998) found significant relations between nutrients and invertebrates at high nutrient concentrations, around the 75th percentile for total inorganic nitrogen (TIN) $(3.63 \mathrm{mg} / \mathrm{L})$ and TP $(0.32 \mathrm{mg} / \mathrm{L})$ in Ohio. Our study found the lowest breakpoint for invertebrates in the nutrientrich CWPE to be $3.28 \mathrm{mg} / \mathrm{L}$ for TN (table 11). Results from our study also suggest that the median annual nutrient concentrations need to be around the initial low-nutrient category classification of $0.01 \mathrm{mg} / \mathrm{L}$ for TP and $0.60 \mathrm{mg} / \mathrm{L}$ for TN to be able to distinguish the low-end breakpoints (figs 4 and 5). This finding was further supported by the large number of significant algae, invertebrate, and fish breakpoints near the 0.60$\mathrm{mg} / \mathrm{L}$ concentration for TN (table 10) in the GNE.

Among the frequently observed responses to increased nutrient concentrations in streams are changes in abundance, density, or richness within biological communities; however, the relations have been inconsistent. Numbers of diatom taxa have been found to increase as TP concentrations increase (Stevenson and others, 2008). Increased nutrient concentrations have been associated with increases in total invertebrate taxon density and richness (Clenaghan and others, 1998; Heino and others, 2003) but also with decreases in richness (Miltner and Rankin, 1998; Wang and others, 2007). Indices of Biological Integrity (IBI) for fish communities have been developed regionally and typically have attributes for number of fish and number of fish taxa. In most streams, but especially in warmwater or coolwater streams, the more fish and fish taxa, the better the water quality - but these increases are not linked directly to increases in nutrient concentrations. However, increased nutrient concentrations have been specifically associated with increases (Lenat and Crawford, 1994) and decreases (Gammon and others, 1999) in fish abundance and fish biomass.

Although previous local or regional studies have found inconsistent responses in the biological community to increases in nutrient concentrations, results from some studies indicate a possible threshold response if there is a sufficient nutrient gradient. In streams in the low-nutrient Mid-Atlantic Highlands, for example, the number of diatom taxa increased as agricultural land use and nutrients increased (Stevenson and others, 2008). In the forested regions of Ireland (Clenaghan and others, 1998) and Finland (Heino and others, 2003), the invertebrate density or richness increased as nutrients increased. In streams in the Piedmont region of North Carolina with low-nutrient concentrations, comparison of forested to agricultural basins showed that fish abundance and number of fish taxa increased as nutrients increased (Lenat and 
Crawford, 1994). When nutrients are added to oligotrophic water bodies, the nutrients provide the fuel for increased production in all biological communities. However, as the nutrient concentrations increase in streams, the response of abundance or richness eventually becomes negative. In contrast to results from studies in low-nutrient areas, studies in Ohio and Wisconsin (where nutrient concentrations generally are higher) showed decreased invertebrate and fish abundance with increasing nutrients (Miltner and Rankin, 1998; Wang and others, 2007). In our study, algal taxa richness decreased with increasing nutrients in the lower nutrient GNE, and fish abundance decreased in the CWPE. The algal taxa richness breakpoints $(1.32 \mathrm{mg} / \mathrm{L}$ for TN and $0.100 \mathrm{mg} / \mathrm{L}$ for TP) and fish abundance breakpoints $(4.73 \mathrm{mg} / \mathrm{L}$ for TN and $0.070 \mathrm{mg} / \mathrm{L}$ for TP) suggest that these are the concentrations where algae and fish abundance or richness begin to decrease. Interestingly, the $1.32-\mathrm{mg} / \mathrm{L}$ breakpoint for TN and $0.07-\mathrm{mg} / \mathrm{L}$ breakpoint for TP are similar to the mesotrophic-eutrophic boundaries of Dodds and others (1998) and Smith and others (2007). Given the findings above, the "intermediate disturbance hypothesis" seems to apply to nutrients as well as hydrological and habitat characteristics such as flooding, substrate size, and refugia (Death and Winterbourn, 1995; Townsend and others, 1997; Lake, 2000). Miltner and Rankin (1998) found the greatest abundance and diversity for fish and invertebrates at the intermediate nutrient concentrations. This finding suggests that determining slope of abundance or richness attributes could be useful in determining the trophic level of streams. If the slope is positive and the nutrient gradient is at the low end, then oligotrophic-mesotrophic conditions are suggested; but if the slope is negative and the nutrient conditions are on the high end, then nutrient saturation and mesotrophic-eutrophic conditions are suggested. An abundance or total-richness attribute alone may not be sufficient to determine the nutrient condition or trophic level of the stream, but it could be a useful tool when multiple lines of evidence are used.

Although invertebrate and fish communities do not have direct attributes specifically linked to nutrients as algae do, excessive nutrient concentrations have been linked to shifts in species composition from functional assemblages of intolerant species, benthic insectivores and top carnivores typical of high-quality warmwater streams towards less desirable assemblages of tolerant species, niche generalists, omnivores, and detritivores typical of degraded warmwater streams (Ohio Environmental Protection Agency, 1999). Miltner and Rankin (1998) found decreases in the number of pollution sensitive species and percent as top carnivore fish in coldwater streams as nutrient concentrations increased. In our study in the GNE, the most significant attributes in the algal, invertebrate, and fish community attributes consisted of fewer intolerant, insectivore, and carnivore species as nutrients increased. However, the biological community composition in the CWPE did not demonstrate these same changes in functional groups because these streams were nutrient saturated. In the GNE, attributes were associated with oligotrophic boundaries for TN $(0.6 \mathrm{mg} / \mathrm{L})$ and TP $(0.025 \mathrm{mg} / \mathrm{L})$ for algae (percent abundance of Achnanthidium minutissimum and the percent richness diatoms preferring eutrophic conditions), invertebrates (number of taxa in the intolerant class), and fish (percent abundance of sensitive fish). This finding suggests that for low-nutrient conditions, multiple lines of evidence from all communities can effectively result in breakpoints with low nutrient concentrations.

Some biological attributes work well for assessing low or high breakpoints for both TN and TP. Other attributes appear to be associated with either TN or TP. Two GNE fish attributes (percent abundance of tolerant fish and percent abundance of piscivorous fish), one CWPE invertebrate attribute (number of taxa in the intolerant class) and one CWPE algae attribute (percent pollution sensitive diatoms (Bahls)) were significantly related only to TP; one CWPE fish attribute (number of darters) was significantly related only to TN. Darters appear to be a good species or attribute to show eutrophication within wadeable stream ecosystems, especially for TN. In the lower nutrient conditions of the GNE, darters increased with increasing nutrients, with a TN breakpoint of $2.46 \mathrm{mg} / \mathrm{L}$. In the higher nutrient conditions of the CWPE, darters decreased with increasing nutrients, with a TN breakpoint of $3.28 \mathrm{mg} / \mathrm{L}$.

The use of the 10th and 75 th percentiles to classify sites into low, medium, and high TN and TP sites effectively showed different species composition within the categories. Because the breakpoints clustered around similar lower and higher concentrations from each biological community within each diatom ecoregion it suggests another possible way to categorize sites along trophic levels based on biological categories. Specifically, the mean concentration of the lower and higher breakpoint values can be used as new biologicallybased thresholds to determine nutrient categories. For TN, the new low and high breakpoints were 1.7 and $3.3 \mathrm{mg} / \mathrm{L}$ in the CWPE and 0.6 and $1.1 \mathrm{mg} / \mathrm{L}$ in the GNE. For TP, the new low and high breakpoints were 0.07 and $0.13 \mathrm{mg} / \mathrm{L}$ in the CWPE and 0.03 and $0.09 \mathrm{mg} / \mathrm{L}$ in the GNE. On the basis of these biological breakpoints, the number of low sites did not change for TN in the CWPE or the GNE, but many of the medium sites were recategorized as high sites in both the CWPE and GNE (table 12). For TP, the new biological breakpoints increased the number of low and high sites.

The initial nutrient categories were based solely on instream nutrient concentrations; but because no measure of nutrient uptake, such as algal biomass, could be used with this dataset, a critical intermediate variable in the nutrient-biological community interactions was missing. For this reason, the responses of the biological communities - which integrate all of the effects of nutrients and subsequent algal growthprobably yield a better assessment of the true nutrient condition of the streams than does a strictly concentration-based categorization. 
Table 12. Comparison of the number of sites in low, medium, and high nutrient categories based on nutrient and biological classifications of stream conditions.

[TN, total nitrogen; TP; total phosphorus; bold, number of sites within a category changed from nutrient (percentiles) to biological (breakpoints) basis for categories]

\begin{tabular}{|c|c|c|c|c|}
\hline \multirow{2}{*}{$\begin{array}{l}\text { Nutrient } \\
\text { category }\end{array}$} & \multicolumn{2}{|c|}{ Nutrient } & \multicolumn{2}{|c|}{ Biological } \\
\hline & $\mathrm{TN}^{1}$ & $\mathrm{TP}^{2}$ & $\mathrm{TN}^{3}$ & $\mathrm{TP}^{4}$ \\
\hline \multicolumn{5}{|c|}{$\begin{array}{l}\text { Central and Western Plains diatom ecoregion (CWPE) } \\
\qquad(\mathrm{n}=31 \text { sites) }\end{array}$} \\
\hline Low & 4 & 4 & 4 & 7 \\
\hline Medium & 18 & 20 & 3 & 11 \\
\hline High & 9 & 7 & 24 & 13 \\
\hline \multicolumn{5}{|c|}{$\begin{array}{l}\text { Glacial North diatom ecoregion (GNE) } \\
\qquad(\mathrm{n}=23 \text { sites) }\end{array}$} \\
\hline Low & 3 & 3 & 3 & 6 \\
\hline Medium & 15 & 13 & 4 & 9 \\
\hline High & 5 & 7 & 16 & 8 \\
\hline
\end{tabular}

${ }^{1}$ Low TN nutrient boundary is $1.74 \mathrm{mg} / \mathrm{L}$ in the CWPE and $0.60 \mathrm{mg} / \mathrm{L}$ in the GNE. High TN nutrient boundary is $7.80 \mathrm{mg} / \mathrm{L}$ in the CWPE and $2.08 \mathrm{mg} / \mathrm{L}$ in the GNE.

${ }^{2}$ Low TP nutrient boundary is $0.05 \mathrm{mg} / \mathrm{L}$ in the CWPE and $0.01 \mathrm{mg} / \mathrm{L}$ in the GNE. High TP nutrient boundary is $0.17 \mathrm{mg} / \mathrm{L}$ in the CWPE and $0.13 \mathrm{mg} / \mathrm{L}$ in the GNE.

${ }^{3}$ Low TN biological boundary is $1.70 \mathrm{mg} / \mathrm{L}$ in the CWPE and $0.60 \mathrm{mg} / \mathrm{L}$ in the GNE. High TN biological boundary is $3.30 \mathrm{mg} / \mathrm{L}$ in the CWPE and $1.10 \mathrm{mg} / \mathrm{L}$ in the GNE.

${ }^{4}$ Low TP biological boundary is $0.07 \mathrm{mg} / \mathrm{L}$ in the CWPE and $0.03 \mathrm{mg} / \mathrm{L}$ in the GNE. High TP biological boundary is $0.13 \mathrm{mg} / \mathrm{L}$ in the CWPE and $0.09 \mathrm{mg} / \mathrm{L}$ in the GNE.

By being able to contrast the biotic responses to a nutrient gradient in a region that still has streams with low nutrient concentrations (GNE) to one that is more nutrient saturated (CWPE), our study showed that biological-community attributes respond as the stream trophic state changes. Some attributes respond at lower nutrient concentrations (oligotrophic), whereas others respond only as the stream becomes eutrophic. Some of these attributes have a positive response (increase with increases in nutrients) and others a negative response (decrease with increases in nutrients). Identifying the significant breakpoints and incorporating the type of biological response helps environmental managers to determine the statistically and ecologically significant attributes that can be used to set water-quality criteria in a specific region.
The findings from our study suggest that the breakpoints clustered around the lower and higher concentration from the GNE could be used as oligotrophic and eutrophic boundaries derived from biological response and not just nutrient concentrations. These oligotrophic and eutrophic boundaries are based on (1) a gradient with sufficiently low to high nutrient concentrations, (2) distinctive differences in the biological communities from the low-nutrient to high nutrient streams, (3) similarity of breakpoints within algal, invertebrate, and fish communities, (4) the significant attributes with either direct relations to nutrients or traditional changes in community structure (that is, decreases in sensitive species or increases in tolerant species), and (5) similar breakpoints in other studies in this and other regions.

\section{Study Limitations}

One of the strengths of the NAWQA Program is that multiple lines of evidence (water chemistry, habitat, and biological community assessments) are used to assess occurrence, distribution, and trends of specific water quality parameters. The costs associated with this intensive sampling, limit the number of sites that can be sampled; within the MRB3 region a total of 54 sites had sufficient nutrient and biological community data to be assessed. The relatively small number of sites with sufficient nutrient and biological-community data in our study somewhat limits the confidence in the classification of the nutrient categories and the breakpoint analysis. However, the similar breakpoint values found in other studies suggests the sample size in this study may have been sufficient. Although algal-community data were available for our study, algal-biomass data - which could have helped determine the true nutrient condition within streams - were not. The algal attributes with nutrient or trophic ties in particular were helpful in understanding low- and high-nutrient conditions. The fact that the central stoneroller - an algivore - was so dominant in several of the low-nutrient CWPE streams suggests that the low stream nutrients may have been from algal uptake rather than oligotrophic conditions. Although these streams were considered less enriched on the basis of measured stream nutrient concentrations, they may have been considered more enriched if algal biomass information had been available. Future studies using data from states within this Major River Basin region that include (1) nutrients, algal biomass, and all biological communities (algal, invertebrate, and fish) and (2) that encompass a sufficiently low nutrient gradient as found in the GNE would be helpful to corroborate the findings presented in this report. 


\section{Summary and Conclusions}

Algal, invertebrate, and fish taxa and attributes that best reflect the effects of nutrients in streams along a gradient of low to high concentrations were determined for this primarily midwestern study. Nutrient data from 64 U.S. Geological Survey sampling sites from the National Water-Quality Assessment (NAWQA) Program - most of which were within the U.S. Environmental Protection Agency (USEPA) Nutrient Ecoregions VI, VII, and VIII-were used to categorize the sites into low-, medium-, and high-nutrient conditions for total nitrogen (TN) and total phosphorus (TP). Nutrient categories were based on approximately the 10th and 75th percentiles of TN and TP concentrations for sites within each of two diatom ecoregions used for subsequent analysis: the Glacial North diatom ecoregion (GNE) and the Central and Western Plains diatom ecoregion (CWPE). "Low-nutrient sites" were those with concentrations at or below the 10th percentile for TN and TP, and "high-nutrient sites" were those at or above the 75th percentile; "medium-nutrient sites" were in between these two concentrations. Annual median TN and TP concentrations by nutrient category and diatom ecoregion were as follows:

[mg/L, milligrams per liter; <, less than; >, greater than]

\begin{tabular}{lrcc}
\hline \multirow{2}{*}{ Nutrient } & \multicolumn{3}{c}{ Nutrient category } \\
\cline { 2 - 4 } & $\begin{array}{c}\text { Low } \\
\text { sites }\end{array}$ & $\begin{array}{c}\text { Medium } \\
\text { sites }\end{array}$ & $\begin{array}{l}\text { High } \\
\text { sites }\end{array}$ \\
\hline & & & \\
\hline Total nitrogen $(\mathrm{mg} / \mathrm{L})$ & $<1.74$ & $1.74-7.80$ & $>7.80$ \\
Total phosphorus (mg/L) & $<.05$ & $.05-.17$ & $>.17$ \\
\hline & & & \\
\hline Total nitrogen $(\mathrm{mg} / \mathrm{L})$ & $<0.60$ & $0.60-2.08$ & $>2.08$ \\
Total phosphorus $(\mathrm{mg} / \mathrm{L})$ & $<.01$ & $.01-.13$ & $>.13$ \\
\hline
\end{tabular}

A total of 54 of these sites with at least 6 nutrient samples and with algal-, invertebrate-, and fish-community data collected within a year were included for further study. Nonparametric statistical analyses were used to determine whether there were regional differences between the algal, invertebrate, and fish communities. The biological communities were significantly different between northern sites (primarily in the GNE) and the southern sites (primarily in the CWPE). In general, TN and TP concentrations were 3-5 times greater in the nutrient-rich CWPE than in the GNE.

In the nutrient-rich CWPE, algae were the best indicators of differences between all of the nutrient categories for both TN and TP; however, in the less nutrient-rich GNE, invertebrates were more indicative of differences between the nutrient categories. Seasonally, the greatest nutrient concentrations in the low-, medium-, and high-nutrient categories were found in the spring, after the application of fertilizer to fields; concentrations decreased steadily from June through October because of (1) nutrient uptake from crops and terrestrial plants, (2) nutrient uptake by algae and macrophytes in streams, and
(3) decreased nutrient runoff to streams from drier soils, which are better able to absorb precipitation. The difference between sites in the nutrient categories was the magnitude and amount of time the elevated nutrient concentrations were found in the stream. An analysis of the nutrient variables annual average, annual maximum, and value closest to the timing of the biological sample found that annual average concentration had the highest correlation to the biotic-community assemblage in the two diatom ecoregions.

Certain species of algae, invertebrates, and fish were more prevalent in low- and high-nutrient conditions within each of the diatom ecoregions. In high-nutrient conditions of the CWPE, 12 species in 3 genera dominated the algal community. For high-TP conditions, the most abundant species were five Navicula species (recens, minima, subminuscula, erifuga, and trivalis), three Nitzschia species (amphibia, palea, and palea debilis), and one Cyclotella species (meneghiniana). For high-TN conditions, the most abundant were four Navicula species (cryptotonella, subminiscula, palea, and symmetrica). Additionally, Pseudostaurosira brevistriata preferred low-TN and low-TP conditions. Six species from the family Fragilariaceae were found exclusively in low-TN conditions. In the GNE, for low-TN and low-TP conditions, Achnanthidium minutissimum and Achnanthidium deflexum dominated the algal community with about 25 and 30 percent of the relative abundance, respectively. For invertebrates, three taxa indicated low-nutrient conditions for both TN and TP in CWPE: Trichoptera Hydropsychidae Ceratopsyche sp., Ephemeroptera Baetidae Baetis flavistriga, and Coleoptera Psephenidae Psephenus herricki. Four taxa were indicative of high-nutrient (TN and TP) conditions in the CWPE: two Ephemeroptera families (Heptageniidae and Leptohyphidae Tricorythodes sp.), Diptera Chironomidae Stenochironomus sp., and Trichoptera Hydropsychidae Hydropsyche sp. High-TP conditions were also favored by Trichoptera Hydropsychidae Hydropsyche bidens, whereas high-TN conditions were indicated by higher relative abundances of six other taxa: two Diptera genera (Chironomidae Tanytarsus sp. and Empididae Hemerodromia sp.), two Coleoptera Elmidea species (Stenelmis grossa and Macronychus glabratus), a Trichoptera Hydroptilidae Hydroptila sp., and a Tubificida Naididae. For fish communities, Campostoma anomalum (central stoneroller), Semotilus atromaculatus (creek chub), and Rhinichthys atratulus (blacknose dace) were indicative of both low-TN and low-TP conditions in the CWPE; additionally, Luxilus chrysocephalus (striped shiner) and Moxostoma duquesnii (black redhorse) were indicative of low-TP conditions, and Luxilus cornutus (common shiner) and Rhinichthys cataractae (longnose dace) were indicative of low-TN conditions. Within the GNE, Salmo trutta (brown trout) and Cottus sp. (freshwater sculpins) were indicative of both low-TP and low-TN conditions; Cottus bairdii (mottled sculpin), longnose dace, and Lota lota (burbot) were indicative of low-TP conditions, and common shiner, Nocomis biguttatus (hornyhead chub), and mottled sculpin were indicative of low TN. 
There were significant breakpoints for nutrients (TN and TP) and multiple attributes for algae, invertebrates, and fish communities within the CWPE and GNE ecoregions. In general, there were more significant breakpoints, with lower concentrations, in the GNE than the more nutrient-rich CWPE. The low and high breakpoints from all biological communities were generally about 3-5 times higher in the south than the north. In the north (GNE), similar low breakpoints were found for TN with all biological communities (around $0.63 \mathrm{mg} / \mathrm{L}$ ) and for TP with the algae and invertebrate communities (between 0.02 and $0.03 \mathrm{mg} / \mathrm{L}$ ). The significant algal attributes provided a better range of breakpoints than did the attributes for fish or invertebrates; in the CWPE, for example, the invertebrate community did not have any low-TN or lowTP breakpoints. In general, TP had stronger correlations with all of the biological attributes than did TN. In the low-nutrient GNE, the significant attributes in the algae, invertebrate, and fish communities supported the changes in functional groups with increasing nutrient concentration as evidenced by fewer intolerant species, insectivores, and carnivores. In the nutrientrich CWPE, however, similar changes in functional groups were not evident, owing to the nutrient-saturated conditions of these streams. In the low-nutrient GNE, attributes associated with oligotrophic boundaries for TN $(0.6 \mathrm{mg} / \mathrm{L})$ and TP $(0.025$ $\mathrm{mg} / \mathrm{L}$ ) included two attributes for algae (percent abundance of Achnanthidium minutissimum and percent richness diatoms preferring eutrophic conditions), one for invertebrates (number of taxa in the intolerant class), and one for fish (percent abundance of sensitive fish). This result suggests that in low-nutrient conditions, multiple lines of evidence from all biological communities can effectively be used to find lownutrient breakpoints.

The findings from our study suggest that the low and high breakpoints for TN and TP from the GNE could be used as oligotrophic and eutrophic boundaries derived from biological response based on this diatom ecoregion's having (1) a gradient with sufficiently low to high nutrient concentrations, (2) distinctive differences in the biological communities in the low-nutrient to high-nutrient streams, (3) similarity of breakpoints within algal, invertebrate, and fish communities, (4) the significant attributes with either direct relations to nutrients or traditional changes in community structure (that is, decreases in sensitive species or increases in tolerant species), and (5) similar breakpoints in other studies in the GNE and other regions. In nutrient-rich areas like the CWPE, all of the breakpoints were substantially higher than those for the lower-nutrient conditions of the GNE; this finding suggests that streams in the CWPE are nutrient saturated to a level at which low-end breakpoints cannot be detected.

\section{References Cited}

Alexander, R.B., Smith, R.A., Schwarz, G.E., Boyer, E.W., Nolan, J.V., and Brakebill, J.W., 2008, Differences in phosphorus and nitrogen delivery to the Gulf of Mexico from the Mississippi River Basin: Environmental Science \& Technology, v. 42, no. 3, p. 822-830.

Bahls, L.L., 1993, Periphyton bioassessment methods for Montana streams: Helena, Mont., Montana Water Quality Bureau, Department of Health and Environmental Sciences [variously paged].

Barbour, M.T., Gerritsen, Jeroen, Snyder, B.D., and Stribling, J.B., 1999, Rapid bioassessment protocols for use in streams and wadeable rivers-Periphyton, benthic macroinvertebrates, and fish ( $2 \mathrm{~d}$ ed.): Washington, D.C., U.S. Environmental Protection Agency, Office of Water Report EPA841B-99-002 [variously paged].

Barnes, M.D., Rice, D.L., and Linkous, T.E., 1985, New locality records of the longnose dace, Rhinichthys cataractae (Cyprinidae), in the upper Ohio River Valley: Ohio Journal of Science, v. 85, no. 3, p. 135-136.

Biggs, B.J.F., 1995, The contribution of flood disturbance, catchment geology and land use to the habitat template of periphyton in stream ecosystems: Freshwater Biology, v. 33, no. 3, p. 419-438.

Biggs, B.J.F., 2000, Eutrophication of streams and riversDissolved nutrient-chlorophyll relationship for benthic algae: Journal of the North American Benthological Society, v. 19 , no. 1 , p. $17-31$.

Biggs, B.J.F., and Smith, R.A., 2002, Taxonomic richness of stream benthic algae-Effects of flood disturbance and nutrients: Limnology and Oceanography, v. 47, no. 4, p. 1175-1186.

Breiman, Leo, Freidman, J.H., Olshen, R.A., and Stone, C.J., 1984, Classification and regression trees: Belmont, Calif., Wadsworth International Group, 368 p.

Bryce, S.A., and Hughes, R.M., 2003, Variable assemblage responses to multiple disturbance gradients - Case studies in Oregon and Appalachia, in Simon, T.P., ed., Biological response signatures - Indicator patterns using aquatic communities: Boca Raton, Fla., CRC Press, p. 539-560.

Carlisle, D.M., and Meador, M.R., 2007, A biological assessment of streams in the eastern United States using a predictive model for macroinvertebrate assemblages: Journal of the American Water Resources Association, v. 43, no. 5, p. 1194-1207. 
Caskey, B.J., and Frey, J.W., 2009, Biological-community composition in small streams and its relations to habitat, nutrients, and land use in agriculturally dominated landscapes in Indiana and Ohio, 2004, and implications for assessing nutrient conditions in Midwest streams: U.S. Geological Survey Scientific Investigations Report 2009-5055, $21 \mathrm{p}$.

Caskey, B.J., Frey, J.W., and Selvaratnam, Shivi, 2010, Breakpoint analysis and assessment of selected stressor variables on benthic macroinvertebrate and fish communities in Indiana streams-Implications for developing nutrient criteria: U.S. Geological Survey Scientific Investigations Report 2010-5026, 35 p.

Charles, D.F., Knowles, C., and Davis, R.S., eds., 2002, Protocols for the analysis of algal samples collected as part of the U.S. Geological Survey National Water-Quality Assessment Program: Philadelphia, Pa., Academy of Natural Sciences, Patrick Center for Environmental Research, Report No. 02-06, 124 p.

Cholnoky, B.J., 1968, Die Ökologie der Diatomeen in Binnengewässern: Lehre, Germany, J. Cramer, 699 p.

Clarke, K.R., and Ainsworth, M., 1993, A method of linking multivariate community structure to environmental variables: Marine Ecology Progress Series, v. 92, p. 205-219.

Clarke, K.R., and Gorley, R.N., 2006a, Primer-E version 6 for Windows (computer software): Plymouth, United Kingdom, Primer-E Ltd.

Clarke, K.R., and Gorley, R.N., 2006b, PRIMER v6-Users manual/tutorial: Plymouth, United Kingdom, Primer-E Ltd.

Clarke, K.R., and Warwick, R.M., 2001, Change in marine communities-An approach to statistical analysis and interpretation ( $2 \mathrm{~d}$ ed.): Plymouth, United Kingdom, Primer-E Ltd.

Clenaghan, C., Giller, P.S., O’Halloran, J., and Hernan, R., 1998, Stream macroinvertebrate communities in a coniferafforested catchment in Ireland-Relationships to physicochemical and biotic factors: Freshwater Biology, v. 40, no. 1, p. 175-193.

Crain, A.S., and Caskey, B.J., 2010, Breakpoint analysis and relations of nutrient and turbidity stressor variables to macroinvertebrate integrity in streams in the Crawford-Mammoth Cave Uplands Ecoregion, Kentucky, for the development of nutrient criteria: U.S. Geological Survey Scientific Investigations Report 2010-5164, 29 p.

Cuffney, T.F., 2003, User's manual for the National WaterQuality Assessment Program Invertebrate Data Analysis System (IDAS) software-Version 3: U.S. Geological Survey Open File Report 03-172, 103 p.
Cuffney, T.F., Gurtz, M.E., and Meador, M.R., 1993, Methods for collecting benthic invertebrate samples as part of the National Water-Quality Assessment Program: U.S. Geological Survey Open-File Report 93-406, 66 p.

De'ath, Glenn, 2002, Mulitvariate regression trees-A new technique for modeling species-environment relationships: Ecology, v. 83, no. 4, p. 1105-1117.

Death, R.G., and Winterbourn, M.J., 1995, Diversity patterns in stream benthic invertebrate communities-The influence of habitat stability: Ecology, v. 76, no. 5, p. 1446-1460.

Dodds, W.K., Jones, J.R., and Welch, E.B., 1998, Suggested classification for stream trophic state-Distributions of temperate stream types by chlorophyll, total nitrogen and phosphorus: Water Research, v. 32, no. 5, p. 1455-1462.

Dodds, W.K., Smith, V.H., and Lohman, Kirk, 2002, Nitrogen and phosphorus relationships to benthic algal biomass in temperate streams: Canadian Journal of Fisheries and Aquatic Sciences, v. 59, no. 5, p. 865-874.

Efron, Bradley, and Tibshirani, R.J., 1993, An introduction to the bootstrap: Boca Raton, FL, Chapman and Hall/CRC, $436 \mathrm{p}$.

eNature.com, 2009, Common shiner, accessed December 26, 2009, at http://www.enature.com/fieldguides/detail. asp? recnum $=$ FI0422.

Figueroa-Nieves, Débora, Royer, T.V., and David, M.B., 2006, Controls on chlorophyll- $a$ in nutrient-rich agricultural streams in Illinois, USA: Hydrobiologia, v. 568, no. 1, p. 287-298.

Fishman, M.J., 1993, Methods of analysis by the U.S. Geological Survey National Water-Quality Laboratory-Determination of inorganic and organic constituents in water and fluvial sediments: U.S. Geological Survey Open-File Report 93-125, $217 \mathrm{p}$.

Fore, L.S., 2003, Developing biological indicators: lessons learned from mid-Atlantic streams: Fort Meade, Md., U.S. Environmental Protection Agency, Environmental Science Center, EPA/903/R-03/003, 41 p.

Fore, L.S., and Grafe, Cynthia, 2002, Using diatoms to assess the biological condition of large rivers in Idaho (U.S.A.): Freshwater Biology, v. 47, p. 2015-2037.

Gammon, J.R., Faatz, W.C., and Simon, T.P., 1999, Patterns in water quality and fish assemblages in three Central Indiana streams with empahasis on animal feed lot operations, in Simon, T.P., ed., Biological response signatures-Indicator patterns using aquatic communities: Boca Raton, Fla., CRC Press, p. 373-417. 
Goldstein, R.M., and Meador, M.R., 2004, Comparisons of fish species traits from small stream to large rivers: Transactions of the American Fisheries Society, v. 133, p. 971-983.

Goolsby, D.A., Battaglin, W.A., Aulenbach, B.T. and Hooper, R.P., 2001, Nitrogen input to the Gulf of Mexico: Journal of Environmental Quality, v. 30, p. 329-336.

Hambrook Berkman, J.A., Scudder, B.C., Lutz, M.A., and Harris, M.A., 2010, Evaluation of aquatic biota in relation to environmental characteristics measured at multiple scales in agricultural streams of the Midwest, 1993-2004: U.S. Geological Survey Scientific Investigations Report 2010-5051, $24 \mathrm{p}$.

Heino, Jani, Muotka, Timo, and Paavola, Riku, 2003, Determinants of macroinvertebrate diversity in headwater streamsRegional and local influences: Journal of Animal Ecology, v. 72 , no. 3 , p. $425-434$.

Hill, B.H., Herlihy, A.T., Kaufmann, P.R., Stevenson, R.J., McCormick, F.H., and Burch Johnson, C., 2000, Use of periphyton assemblage data as an index of biotic integrity: Journal of the North American Benthological Society, v. 19, no. 1, p. $50-67$.

Indiana Department of Environmental Management, 1999, Summary of protocols - Probability based site assessment for Watershed Program field activities, revision 6, June 12, 2002: Indianapolis, Ind., Indiana Department of Environmental Management, Office of Water Quality, Assessment Branch, IDEM 32/03/002/1999, $32 \mathrm{p}$.

Justus, B.G., Petersen, J.C., Wallace, J.E., Femmer, S.R., and Davis, J.V., 2009, An analysis of algal, macroinvertebrate, and fish community indices for assessing low-level nutrient concentrations in wadeable Ozark streams, in North American Benthological Society annual meeting, 57th, Grand Rapids, Mich., May 16-23, 2009: North American Benthological Society.

Karr, J.R., Fausch, K.D., Angermeier, P.L., Yant, P.R., and Schlosser, I.J., 1986, Assessing biological integrity in running waters-A method and its rationale: Champaign, Ill., Illinois Natural History Survey Special Publication 5, 31 p.

Kentucky Division of Water, 2002, Methods for assessing biological integrity of surface waters in Kentucky: Frankfort, Ky., Kentucky Department of Environmental Protection, $189 \mathrm{p}$.

Kilkus, S.P., LaPerriere, J.D., and Bachmann, R.W., 1975, Nutrients and algae in some central Iowa streams: Journal of the Water Pollution Control Federation, v. 47, no. 7, p. $1870-1879$.
Klinger, S.A., Magnuson, J.J., and Gallepp, G.W., 1982, Survival mechanisms of the central mudminnow (Umbra limi), fathead minnow (Pimephales promelas) and brook stickleback (Culaea inconstans) for low oxygen in winter: Environmental Biology of Fishes, v. 7, no. 2, p. 113-120.

Kosinski, R.J., 1984, The effect of terrestrial herbicides on the community structure of stream periphyton: Environmental Pollution Series A, Ecological and Biological, v. 36, no. 2, p. $165-189$.

Kruskal, J.B., 1964a, Multidimensional scaling by optimizing goodness of fit to nonmetric hypothesis: Psychometrika, v. 29 , no. 1, p. $1-27$.

Kruskal, J.B., 1964b, Nonmetric multidimensional scaling-A numerical method: Psychometrika, v. 29, no. 2, p. 115-129.

Kruskal, J.B., and Wish, Myron, 1978, Multidimensional scaling: Newbury Park, Calif., Sage Publications, Quantitative Applications in the Social Sciences (Sage University Paper), v. $11,93 \mathrm{p}$.

Lake, P.S., 2000, Disturbance, patchiness, and diversity in streams: Journal of the North American Benthological Society, v. 19 , no. 4 , p. 573-592.

Lamberti, G.A., and Resh, V.H., 1983, Stream periphyton and insect herbivores - An experimental study of grazing by a caddisfly population: Ecology, v. 64, no. 5, p. 1124-1135.

Lange-Bertalot, H., 1979, Pollution tolerance of diatoms as a criterion for water quality estimation: Nova Hedwigia, v.64, p. 285-304.

Lenat, D.R., and Crawford, J.K., 1994, Effects of land use on water quality and aquatic biota of three North Carolina Piedmont streams: Hydrobiologia, v. 294, no. 3, p. 185-199.

Lorenz, D.L., Robertson, D.M., Hall, D.W., and Saad, D.A., 2009, Trends in streamflow and nutrient and suspendedsediment concentrations and loads in the Upper Mississippi, Ohio, Red, and Great Lakes River Basins, 1975-2004: U.S. Geological Survey Scientific Investigations Report 2008-5123, $82 \mathrm{p}$.

Lowe, B.S., Leer, D.R., Frey, J.W., and Caskey, B.J., 2008, Occurrence and distribution of algal biomass and its relation to nutrients and selected basin characteristics in Indiana streams, 2001-2005: U.S. Geological Survey Scientific Investigations Report 2008-5203, 146 p.

Lowe, R.L., 1974, Environmental requirements and pollution tolerance of freshwater diatoms: Cincinnati, Ohio, U.S. Environmental Protection Agency, Office of Research and Development, National Environmental Research Center, EPA-670/4-74-005, 333 p. 
Lyons, John, 1992, Using the Index of Biotic Integrity (IBI) to measure environmental quality in warm water streams of Wisconsin: St. Paul, Minn., U.S. Department of Agriculture, Forest Service, North Central Experiment Station, General Technical Report NC-149, 48 p.

McCulloch, B.R., 2003, Update COSEWIC status report on the bigmouth shiner Notropis dorsalis in Canada, in COSEWIC assessment and update status report on the bigmouth shiner Notropis dorsalis in Canada: Ottawa, Canada, Committee on the Status of Endangered Wildlife in Canada, $20 \mathrm{p}$.

Meador, M.R., Cuffney, T.F., and Gurtz, M.E., 1993, Methods for sampling fish communities as part of the National Water-Quality Assessment Program: U.S. Geological Survey Open-File Report 93-104, 40 p.

Messaad, I.A., Peters, E.J., and Young, L., 2000, Thermal tolerance of red shiner (Cyprinella lutrensis) after exposure to atrazine, terbufos, and their mixtures: Bulletin of Environmental Contamination and Toxicology, v. 64, p. 748-754.

Miltner, R.J., and Rankin, E.T., 1998, Primary nutrients and the biotic integrity of rivers and streams: Freshwater Biology, v. 40, no. 1 , p. $145-158$.

Mosisch, T.D., Bunn, S.E., and Davies, P.M., 2001, The relative importance of shading and nutrients on algal production in subtropical streams: Freshwater Biology, v. 46, no. 9, p. 1269-1278.

Moulton, S.R., II, Carter, J.L., Grotheer, S.A., Cuffney, T.F., and Short, T.M., 2000, Methods of analysis by the U.S. Geological Survey National Water-Quality Laboratory-Processing, taxonomy, and quality control of benthic macroinvertebrate samples: U.S. Geological Survey Open-File Report 2000-212, 49 p.

Moulton S.R., II, Kennen, J.G., Goldstein, R.M., and Hambrook, J.A., 2002, Revised protocols for sampling algal, invertebrate, and fish communities as part of the National Water-Quality Assessment Program: U.S. Geological Survey Open-File Report 02-150, 75 p.

Mueller, D.K., and Spahr, N.E., 2006, Nutrients in streams and rivers across the Nation, 1992-2001: U.S. Geological Survey Scientific Investigations Report 2006-5107, 44 p.

Munn, M.D., Frey, J.W., and Tesoriero, A.J., 2010, The influence of nutrients and physical habitat in regulating algal biomass in agricultural streams: Journal of Environmental Management, v. 45, no. 3, p. 603-615.

Munn, M.D., and Hamilton, P.A., 2003, New studies initiated by the U.S. Geological Survey-Effects of nutrient enrichment on stream ecosystems: U.S. Geological Survey Fact Sheet FS-118-03, 4 p.
Munn, M.D., Osborne, L.L., and Wiley, M.J., 1989, Factors influencing periphyton growth in agricultural streams of central Illinois: Hydrobiologia, v. 174, no. 2, p. 89-97.

Ohio Environmental Protection Agency, 1987a, Biological criteria for the protection of aquatic life-Volume II, Users manual for biological field assessment of Ohio surface waters: Columbus, Ohio, Ohio Environmental Protection Agency [variously paged] (also available at http://web.epa. ohio.gov/dsw/bioassess/BioCriteriaProtAqLife.html).

Ohio Environmental Protection Agency, 1987b, Water quality implementation manual: Columbus, Ohio, Ohio Environmental Protection Agency [variously paged].

Ohio Environmental Protection Agency, 1989, Biological criteria for the protection of aquatic life-Volume III, Standardized biological field sampling and laboratory methods, for assessing fish and macroinvertebrate communities: Columbus, Ohio, Ohio Environmental Protection Agency [variously paged] (also available at http://web.epa.ohio.gov/ $d s w /$ bioassess/BioCriteriaProtAqLife.html).

Ohio Environmental Protection Agency, 1999, Association between nutrients, habitat, and the aquatic biota in Ohio rivers and streams: Columbus, Ohio, Ohio Environmental Protection Agency Technical Bulletin MAS/1999-1-1, 78 p.

Omernik, J.M., 1987, Ecoregions of the conterminous United States, Map (scale 1:7,500,000): Annals of the Association of American Geographers, v. 77, no. 1, p. 118-125.

Omernik, J.M., 1995, Ecoregions-A spatial framework for environmental management, in Davis, W.S., and Simon, T.P., eds., Biological assessment and criteria-Tools for water resource planning and decision making: Boca Raton, Fla., Lewis Publishers, p. 49-62 (also available at http:// books.google.com/books? hl=en\&lr $=\& i d=4 Y 8 k i w l O 5 q A C \&$ $o i=f n d \& p g=P A 3 \& d q=\% 22$ Davis $\% 22+\% 22$ Biological + ass essment + and + criteria $:+$ tools + for + water $+\ldots \% 22+\& o t s=v y$ S435nRg6\&sig=RDgIs8AkQYzl4KhkQWFZH6jxjhE).

Passy, S.I., 2000, Stream biomonitoring in New York using periphytic diatoms: Albany, N.Y., New York State Department of Environmental Conservation, Stream Biomonitoring Unit, $14 \mathrm{p}$.

Patton, C.J., and Truitt, E.P., 1992, Methods of analysis by the U.S. Geological Survey National Water Quality Laboratory-Determination of total phosphorus by a kjeldahl digestion method and an automated colorimetry finish that includes dialysis: U.S. Geological Survey Open-File Report 92-146, 39 p. 
Patton, C.J., and Truitt, E.P., 2000, Methods of analysis by the U.S. Geological Survey National Water Quality Laboratory-Determination of ammonium plus organic nitrogen by a Kjeldahl digestion method and an automated photometric finish that includes digest cleanup by gas diffusion: U.S. Geological Survey Open-File Report 00-170, 31 p.

Porter, S.D., 2008, Algal attributes-An autecological classification of algal taxa: U.S. Geological Survey Data Series 329, 18 p.

Porter, S.D., Cuffney, T.F., Gurtz, M.E., and Meador, M.R., 1993, Methods for collecting algal samples as part of the National Water-Quality Assessment Program: U.S. Geological Survey Open-File Report 93-409, 39 p.

Porter, S.D., Mueller, D.K., Spahr, N.E., Munn, M.D., and Dubrovsky, N.M., 2008, Efficacy of algal metrics for assessing nutrient and organic enrichment in flowing waters: Freshwater Biology, v. 53, p. 1036-1054.

Potapova, Marina, and Charles, D.F., 2007, Diatom metrics for monitoring eutrophication in rivers of the United States: Ecological Indicators, v. 7, p. 48-70.

Power, M.E., 1992, Hydrologic and trophic controls of seasonal algal blooms in northern California rivers: Archiv für Hydrobiologie, v. 125 , no. 4, p. 385-410.

Pringle, C.M., 1990, Nutrient spatial heterogeneity-Effects on community structure, physiognomy, and diversity of stream algae: Ecology, v. 71, no. 3, p. 905-920.

Qian, S.S., King, R.S., and Richardson, C.J., 2003, Two statistical methods for the detection of environmental thresholds: Ecological Modelling, v. 166, no. 1-2, p. 87-97.

Rankin, E.T., Miltner, R.J., Yoder, C.O., and Mishne, D.A., 1999, Association between nutrients, habitat, and the aquatic biota in Ohio rivers and streams: Columbus, Ohio, Ohio EPA Technical Bulletin MAS/1999-1-1, 78 p.

Resh, V.H., and Unzicker, J.D., 1975, Water quality monitoring and aquatic organisms - The importance of species indentification: Journal of the Water Pollution Control Federation, v. 47, no. 1, p. 9-19.

Robertson, D.M., Graczyk, D.J., Garrison, P.J., Wang, Lizhu, LaLiberte, Gina, and Bannerman, Roger, 2006, Nutrient concentrations and their relations to the biotic integrity of wadeable streams in Wisconsin: U.S. Geological Survey Professional Paper 1722, 139 p.

Robertson, D.M., Weigel, B.M., and Graczyk, D.J., 2008, Nutrient concentrations and their relations to the biotic integrity of nonwadeable rivers in Wisconsin: U.S. Geological Survey Professional Paper 1754, 81 p.
Shelton, L.R., 1994, Field guide for collecting and processing stream-water samples for the National Water-Quality Assessment Program: U.S. Geological Survey Open File Report 94-455, 42 p. (also available at http://pubs.er.usgs. gov/djvu/OFR/1994/ofr_94_455.djvu).

Shepard, R.N., 1962, The analysis of proximities - multidimensional scaling with an unknown distance function. I: Psychometrika, v. 27, no. 2, p. 125-140.

Simon, T.P., 1991, Development of Index Biotic Integrity expectations for the ecoregions of Indiana-Central Corn Belt Plain: Chicago, Ill., U.S. Environmental Protection Agency, Watershed and Non-Point Source Branch, EPA 905/9-91/025, 106 p.

Simon, T.P., 1997, Development of Index Biotic Integrity expectations for the ecoregions of Indiana-Northern Indiana Till Plain: Chicago, Ill., U.S. Environmental Protection Agency, Watershed and Non-Point Source Branch, EPA 905/R-96/002, 187 p.

Smith, A.J., Bode, R.B., and Kleppel, G.S., 2007, A nutrient biotic index (NBI) for use with benthic macroinvertebrate communities: Ecological Indicators, v. 7, no. 2, p. 371-386.

Stevenson, R.J., Pan, Yangdong, Manoylov, K.M., Parker, C.A., Larsen, D.P., and Herlihy, A.T., 2008, Development of diatom indicators of ecological conditions for streams of the western US: Journal of the North American Benthological Society, v. 27, no. 4, p. 1000-1016.

Teply, Mark, and Bahls, Loren, 2005, Diatom biocriteria for Montana streams: Helena, Mont., Prepared for the Montana Department of Environmental Quality, Water Quality Monitoring Section, $22 \mathrm{p}$.

Tetra Tech, 2009, Change-point analysis, accessed December 28, 2009, at http://n-steps.tetratech-ffx.com/ PDF\&otherFiles/stat_anal_tools/Change\%20Point_final. $p d f$.

TIBCO, 2008, Release notes for TIBCO Spotfire S+ 8.1 for Windows (computer software): Somerville, Mass.

Townsend, C.R., Scarsbrook, M.R., and Dolédec, Sylvain, 1997, The intermediate disturbance hypothesis, refugia, and biodiversity in streams: Limnology and Oceanography, v. 42, no. 5, p. 938-949.

U.S. Environmental Protection Agency, 1993, Method 365.1Determination of phosphorus by semi-automated colorimetry: Cincinnati, Ohio, Office of Research and Development Environmental Monitoring Systems Laboratory, 17 p.

U.S. Environmental Protection Agency, 1997, National Water Quality Inventory - 1996 report to Congress: Washington, D.C., EPA 841-R-97-008, 527 p. (also available at http://www.epa.gov/305b/96report/index.html). 
U.S. Environmental Protection Agency, 2000a, Ambient water quality criteria recommendations - Information supporting the development of state and tribal nutrient criteria-rivers and streams in Nutrient Ecoregion IX: Washington, D.C., Office of Water, EPA 822-B-00-019, 108 p.

U.S. Environmental Protection Agency, 2000b, Ambient water quality criteria recommendations - Information supporting the development of state and tribal nutrient criteria-rivers and streams in Nutrient Ecoregion VII: Washington, D.C., Office of Water, EPA 822-B-00-018, 93 p.

U.S. Environmental Protection Agency, 2000c, Nutrient criteria technical guidance manual-Lakes and reservoirs: Washington, D.C., EPA-822-B00-001, 232 p.

U.S. Environmental Protection Agency, 2000d, Nutrient criteria technical guidance manual-Rivers and streams: Washington, D.C., EPA-822-B00-002, 253 p.

U.S. Environmental Protection Agency, 2003, Developing biological indicators - Lessons learned from Mid-Atlantic streams: Ft. Meade, Md., Environmental Science Center, EPA/903/R-03/003, 41 p.

U.S. Environmental Protection Agency, 2005, Water quality criteria - Current national recommended water quality criteria: Biological and Economic Analysis Division, Office of Pesticide Programs, Office of Prevention, Pesticides, and Toxic Substances, accessed September 15, 2005, at http://www.epa.gov/waterscience/criteria/wqctable/.

U.S. Environmental Protection Agency, 2006a, Developing biological indicators - Lessons learned from Mid-Atlantic streams: Ft. Meade, Md., Environmental Science Center,

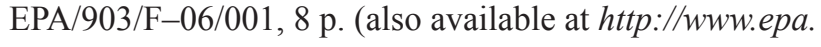
gov/bioiweb1/pdf/EPA-903-F-06-001DevelopingBiologi calIndicatorsLessonsLearnedfromMid-AtlanticStreamsBrochure.pdf).

U.S. Environmental Protection Agency, 2006b, Wadeable streams assessment-A collaborative survey of the Nation's streams: Washington, D.C., Office of Research and Development, Office of Water, EPA 841-B-06-002, 113 p. (also available at $h t t p: / / w w w . e p a . g o v / o w o w / m o n i t o r i n g / w s a /$ factsheet_10_25_06.pdf).
U.S. Environmental Protection Agency, 2010, WaterRegional and state links: Accessed February 10, 2010, at http://www.epa.gov/ow/region.html.

U.S. Geological Survey, 2007, National Water-Quality Assessment Data Warehouse, Fish community data, accessed August 8, 2007, at http://infotrek.er.usgs.gov/.

U.S. Geological Survey, 2008, National Water-Quality Assessment Data Warehouse, Invertebrate community data, accessed February 12, 2008, at http://infotrek.er.usgs.gov/.

U.S. Geological Survey, 2010, National Water-Quality Assessment Regional and National Monitoring and Assessments of Streams and Rivers, accessed February 10, 2010, at http://water.usgs.gov/nawqa/studies/mrb/.

Van Dam, Herman, Mertens, Adrienne, and Sinkeldam, Jos, 1994, A coded checklist and ecological indicator values of freshwater diatoms from the Netherlands: Netherlands Journal of Aquatic Ecology, v. 28, no. 1, p. 117-133.

Wang, Lizhu, Robertson, D.M., and Garrison, P.J., 2007, Linkages between nutrients and assemblages of macroinvertebrates and fish in wadeable streams - Implication to nutrient criteria development: Environmental Management, v. 39, no. 2, p. 194-212.

Wang, Y.-K., Stevenson, R.J., and Metzmeier, L., 2005, Development and evaluation of a diatom-based Index of Biotic Integrity for the Interior Plateau Ecoregion, USA: Journal of the North American Benthological Society, v. 24, no. 4, p. 990-1008.

Wehr, J.D., and Sheath, R.G., eds., 2003, Freshwater algae of North America-Ecology and classification: San Diego, Calif., Academic Press, 918 p. 


